مجلة كلية الآداب، جامعة سوهاج، العدد الثالث والخمسون، الجزء الثاني، أكتوبر 19 • ب م

اتجاهات الشباب الجامعي نـو مؤشرات مصداقية الأفبار بالقنـوات الفضائبة: دراسة ميدانية

هيام شرف الدين أحمد محمد (*)

المقدمة:

تعد القتوات الفضائية الحكومية والخاصة من أكثر الوسائل تعرضًا من قبل فيل

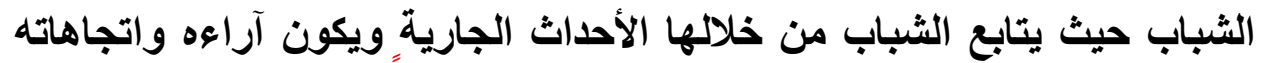

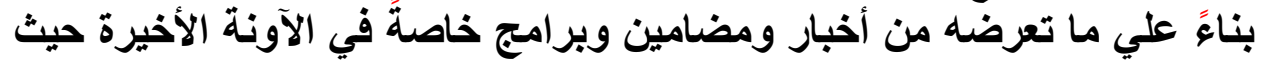

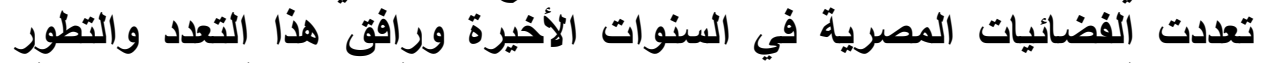

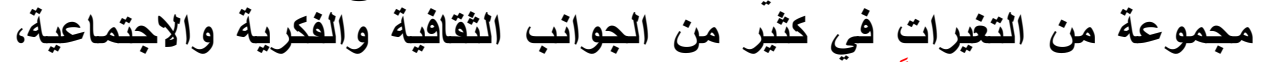

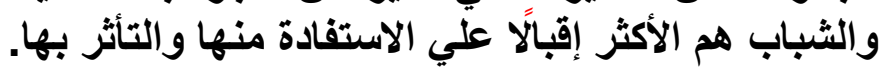

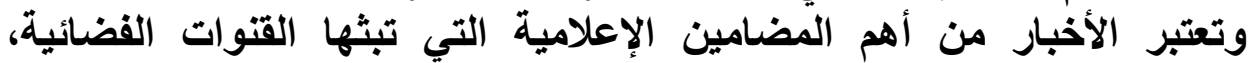

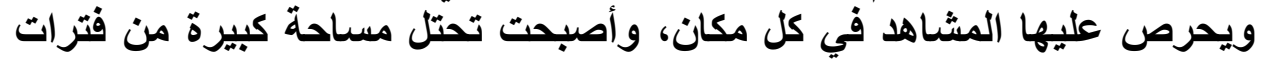

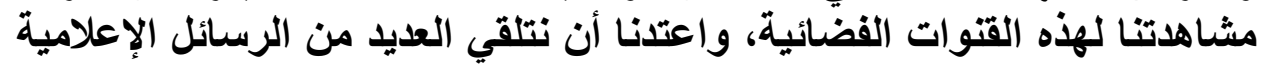

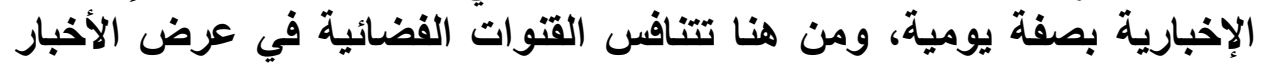

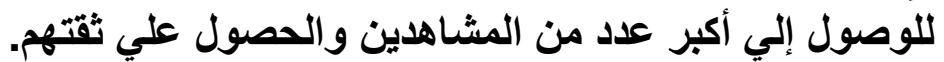

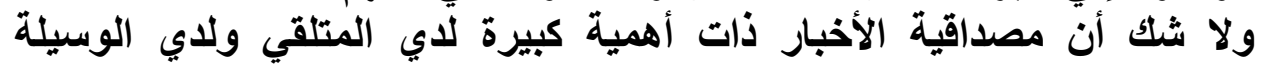

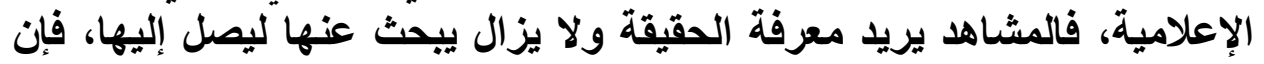

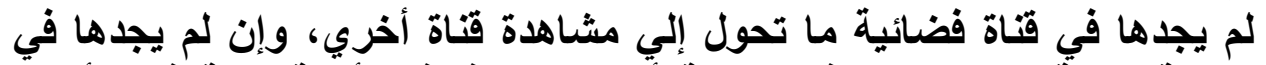

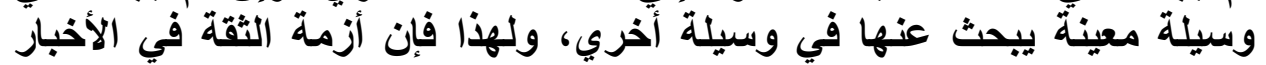

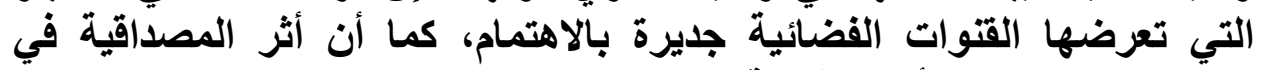

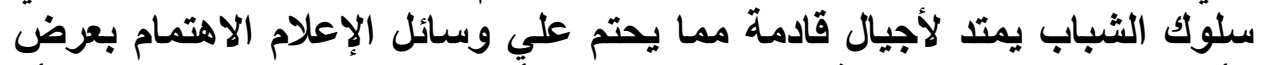

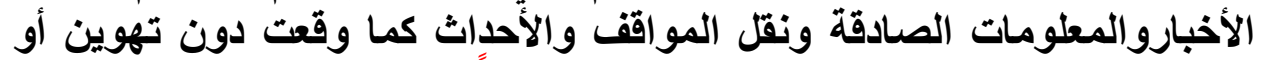

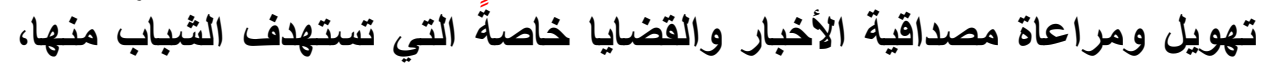

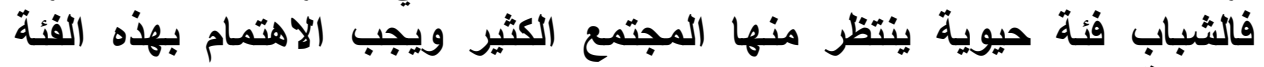

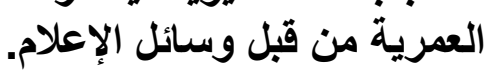
وفي ظل التحولات المتعددة في الإعلام النظم السياسية والاقتصادية والاجتماعية

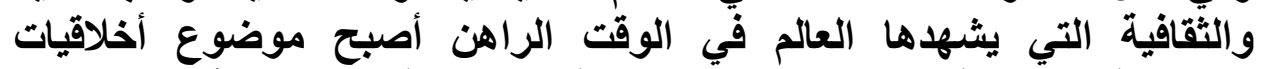

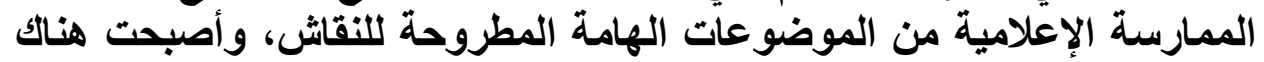

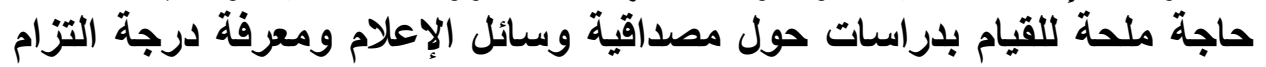

(") هذا البحث من رسالة الماجستير الخاصة بالباحثة، وهي بعنوان: اتجاهات الثباب الجامعي

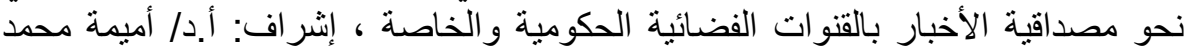

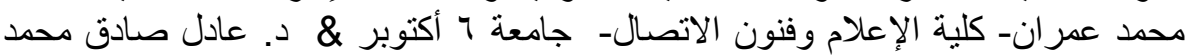
- كلية الآداب - جمامعة سوهاج. 
الوسائل الإعلامية بمعايير ومؤشرات المصداقية وإلي أي مدي يثق جمهورها

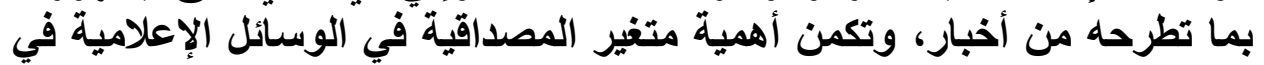

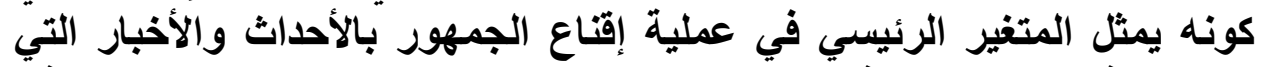

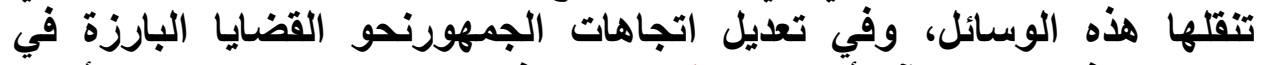

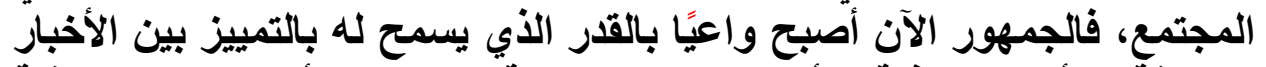

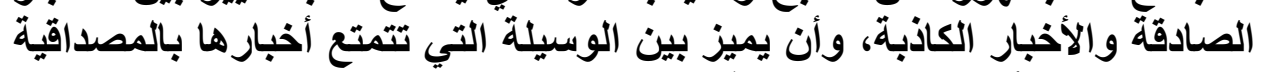
والتي لا تتمتع أخبار ها بالمصدافية وانية.

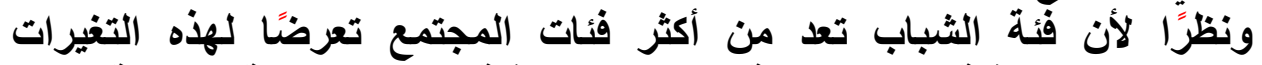

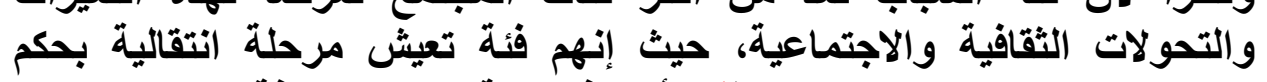

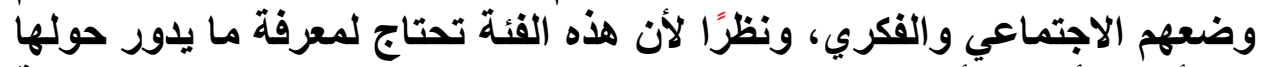

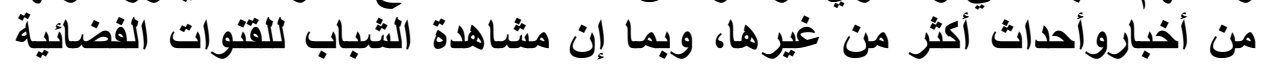

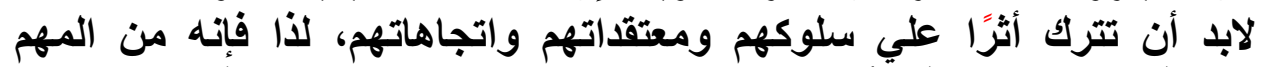

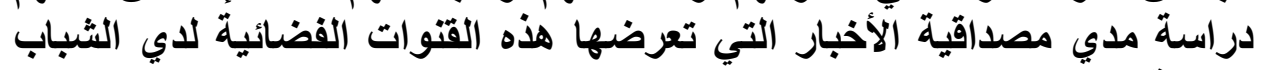
ودرجة ثقتهم بها. وبناءً علي ماسبق تأتي أهمية التعرف علي مدي مصداقية الفية الأخبار بالقتوات

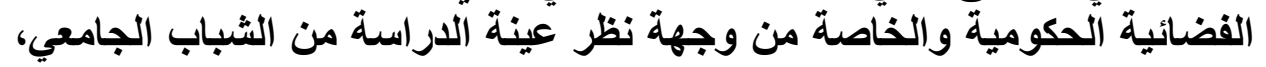

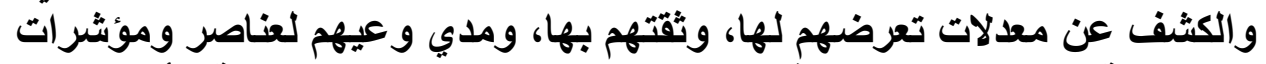

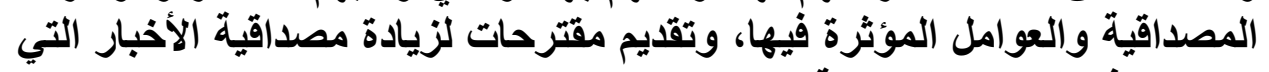
تقدمها هذه القتوات الفضائية.

\section{الإطار المنهجيي}

\section{مشكالة الدراسة :}

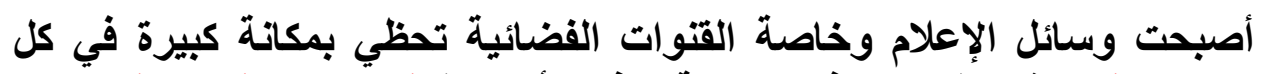

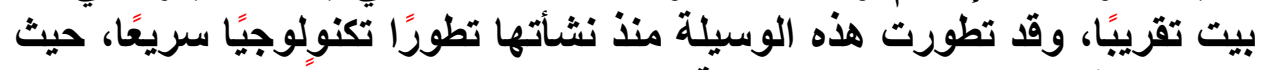

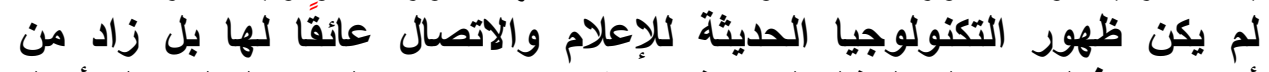

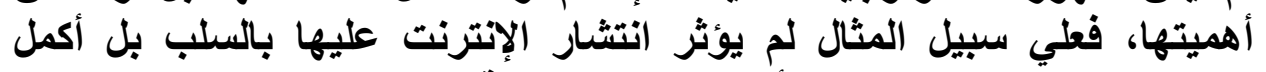

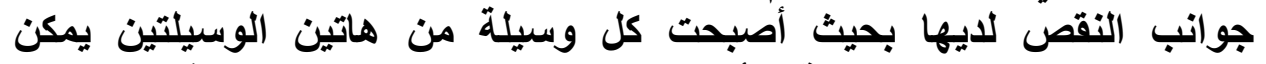

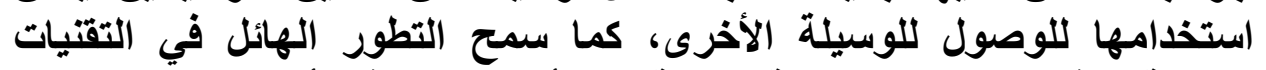

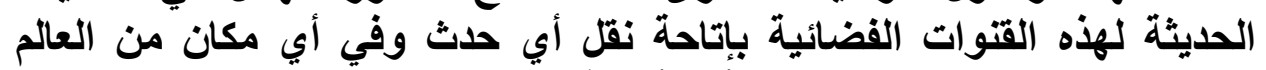

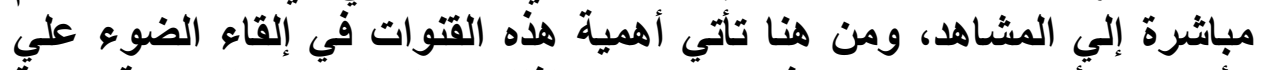

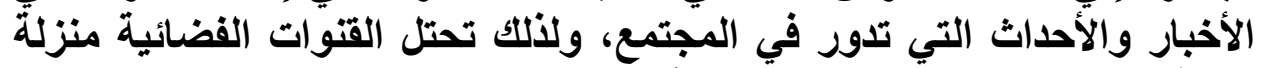

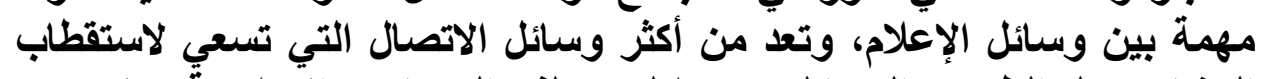

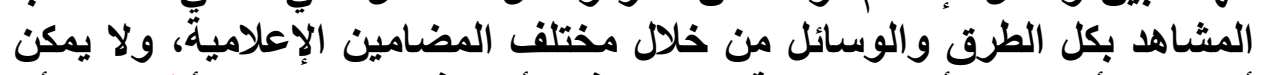

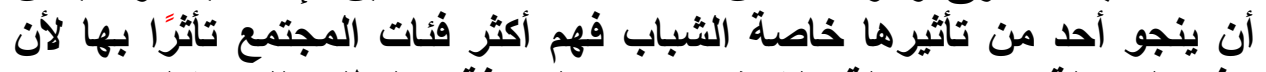

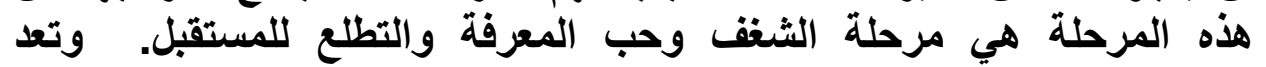




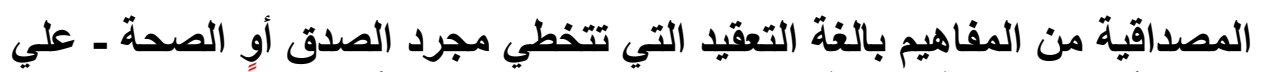

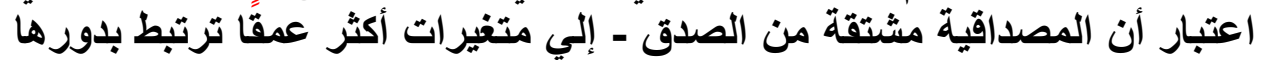

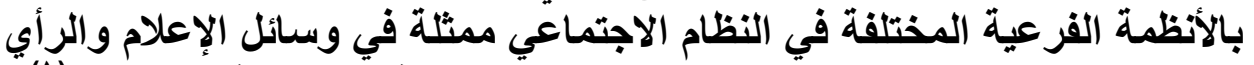

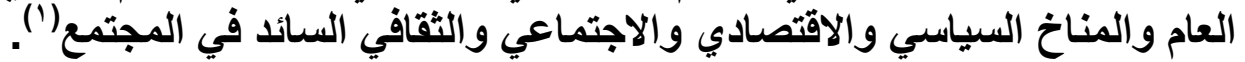

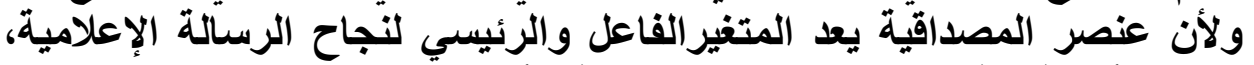

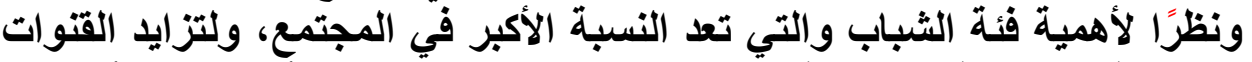

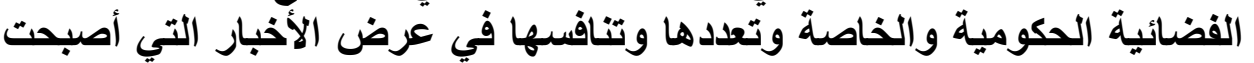

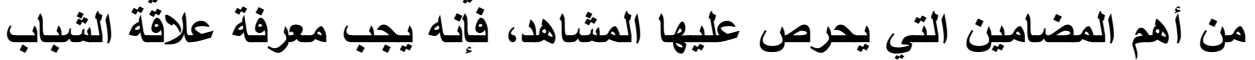
بهذه القتوات الفضائية ومدي ثقته بالأخبار التي تعرضها، وتقييم مصداقية

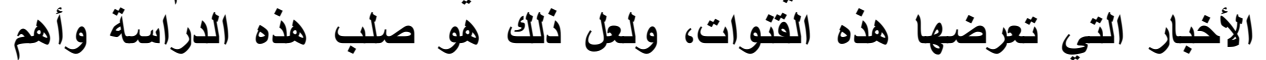

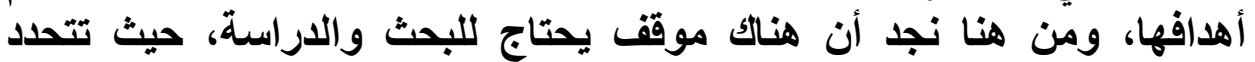

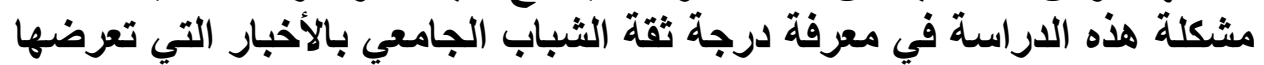

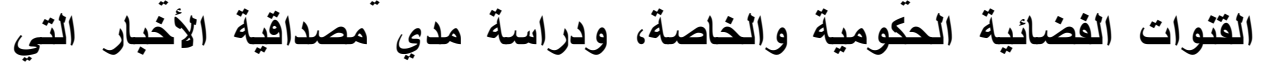

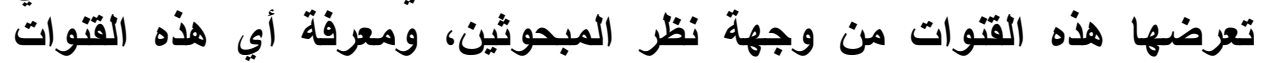

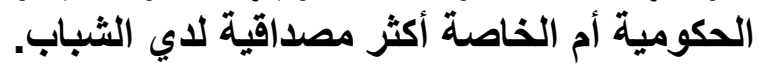

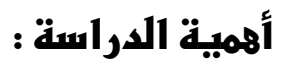

تتحدد أهمية هذه الدراسة بمجموعة من الأمور المترابطة مع بعضها البعض

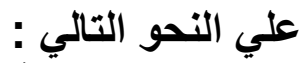

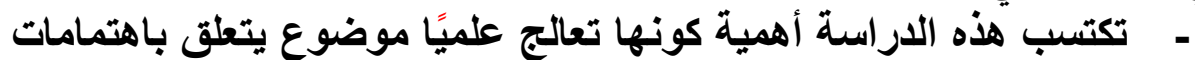

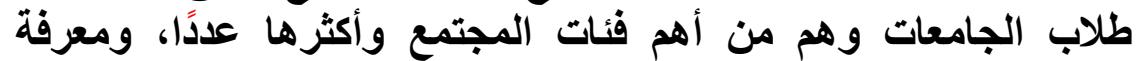

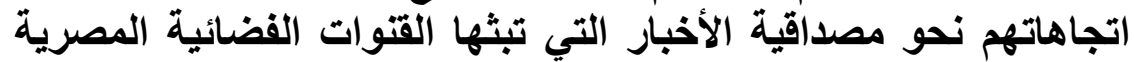
الحكومية والخاصة. - وجود حاجة ملحة لاراسات عربية تتناول مصداقية الأخبار التي تعرضها

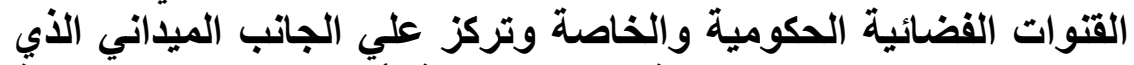

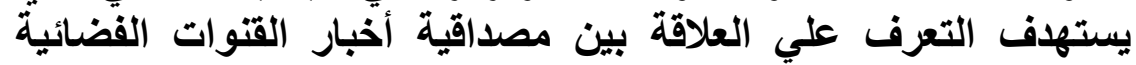

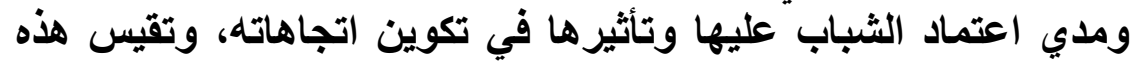

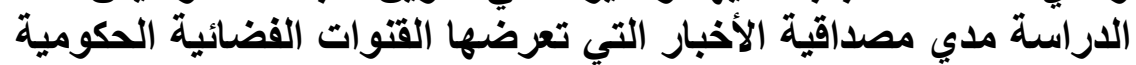
والخاصة لاسي الشباب الجامعي.

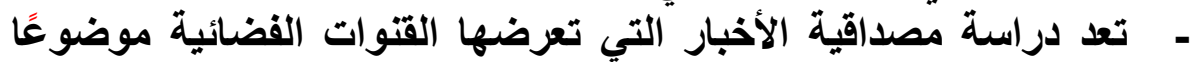

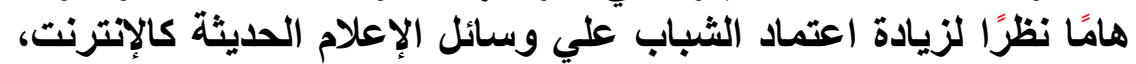

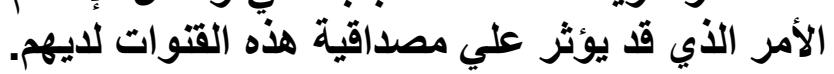

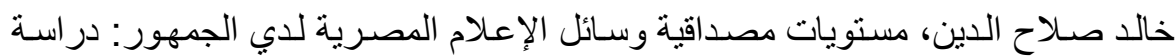

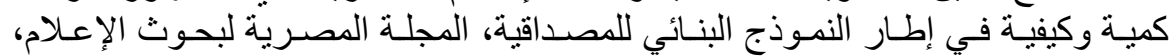

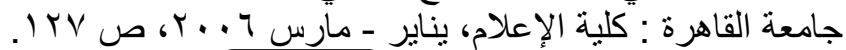


أهداف الدراسة: تسعي الاراسة للوصول إلي عدة أهداف تسعي الدراسة لها، - ألتعرف علي مدي متابعة الثباب الجامعي للأخبار التي تعرضها القتوات الفضائية المصرية الحكومية والخاصة. - تحديد درجة اعتماد الشباب الجامعي علية الفية القنوات الفضائية المصرية في

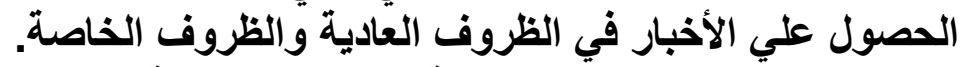

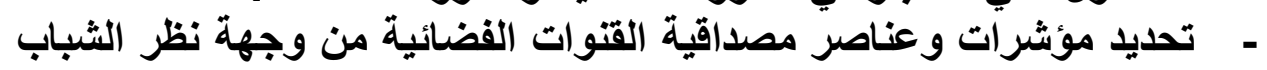

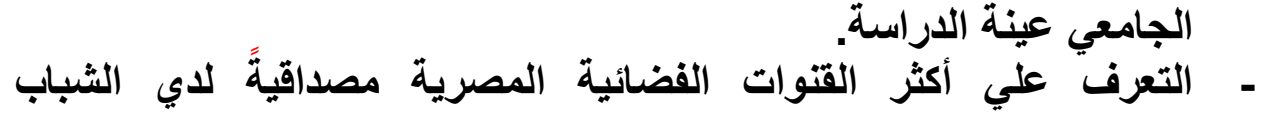
- التعرف علي البديل الإعلامي الذي يلجأ إليه أفراد العينة في حالة عدم ثقتهم

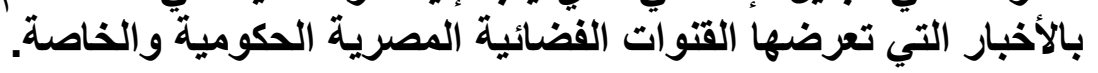

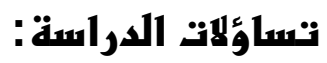

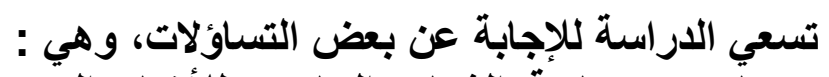

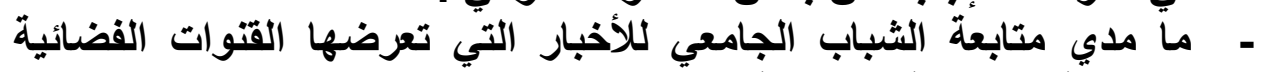

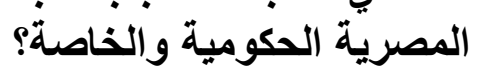
- ما مؤشرات وعناصر مصداقية القية القوات الفضائية من وجهة نظر الثباب

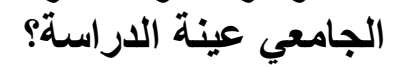
- مأمدي مصداقية الأخبار التي تعرضها القنوات الفضائية المصرية الحكومية

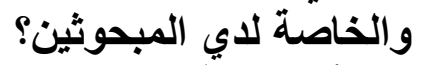
- إلي أي درجة ليعتمد الثباب الجامعي علي القتوات الفضائية المصرية في

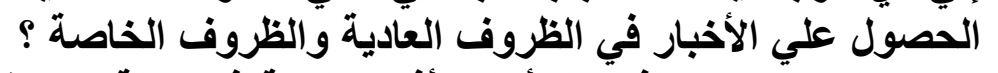

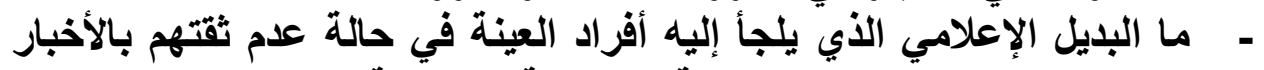

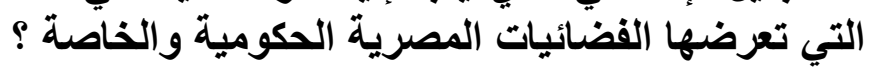

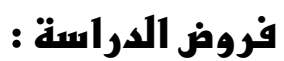

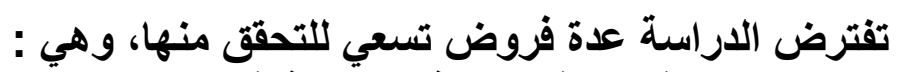

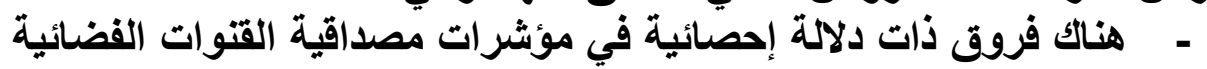

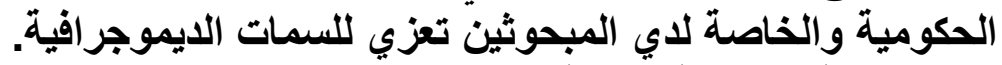

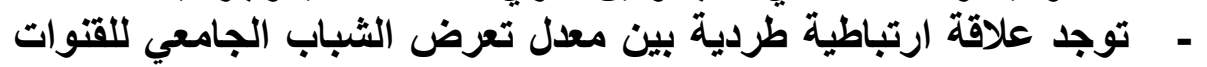

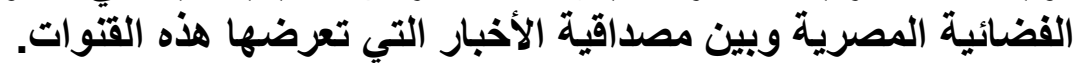

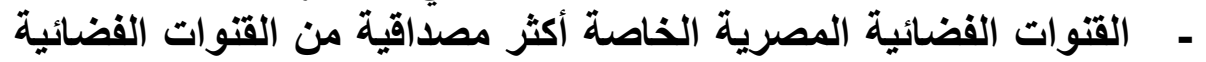
المصرية الحكومية لاي المبحوثين.

ㅍ. 


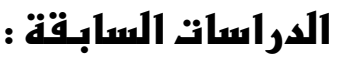

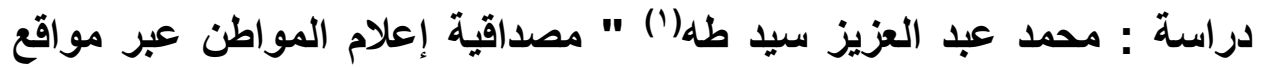

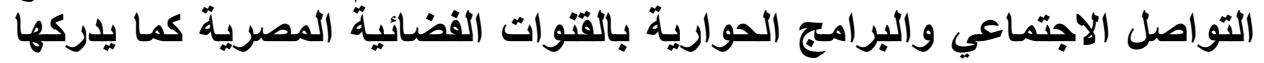

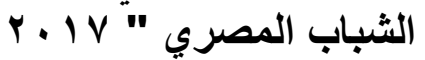
وتهذف الدراسةة إلى التعرف على مستويات مصداقية مضامين إعلام المواطن

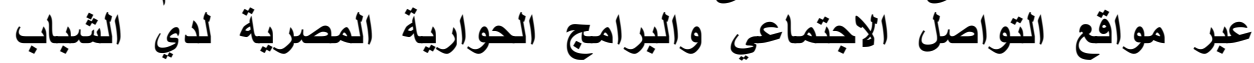

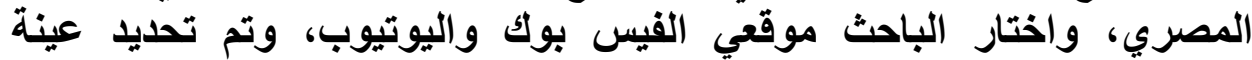

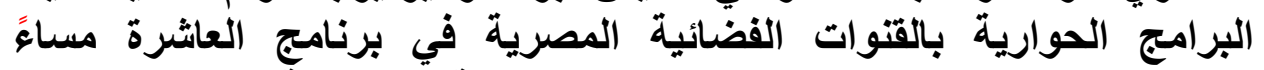

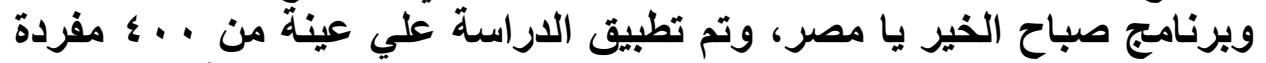

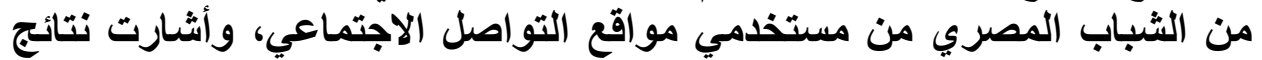

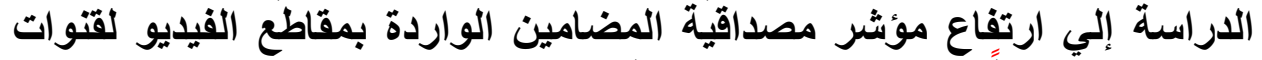

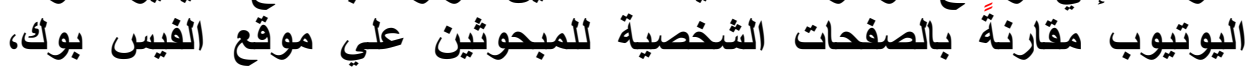

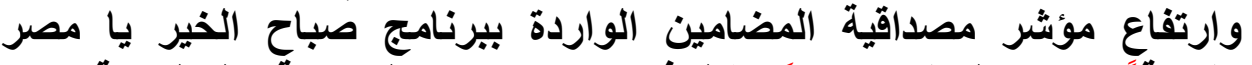

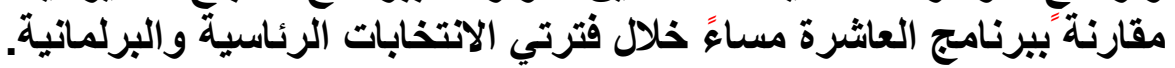

دراسة: رحاب عبدالناصر(r) "مصداقية القنوات التليفزيونية الحكومية والخاصة

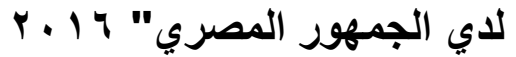
وتهذف الدراسة إلى التعرف على درجة التهات مصداقية القنوات المصرية الحكومية

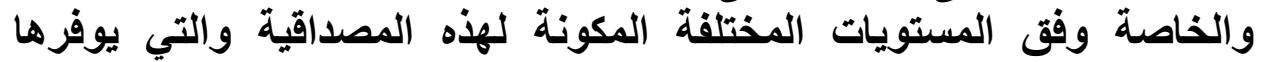

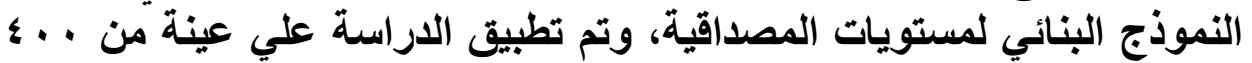

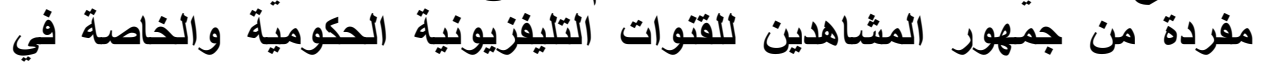
محافظة أسيوط، وأشارت نتائج الدراسة إلي وتوصلت الدراسة إلى إلي وجود علاقة

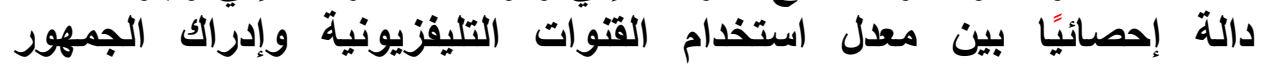

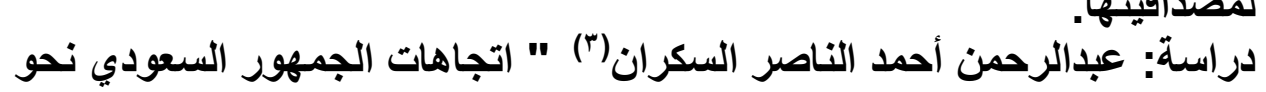

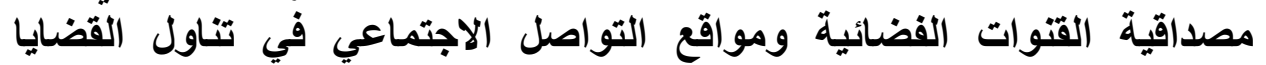

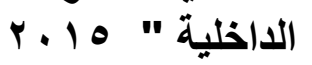

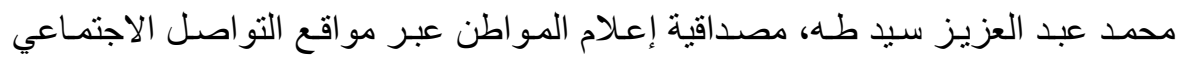

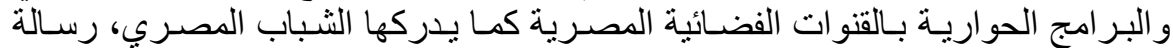

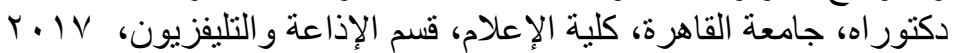

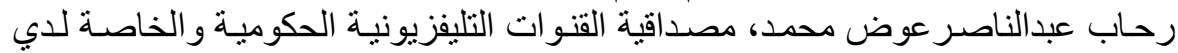
الجمهور المصري، رسالة ماجستير ، جامعة أسيوط، كلية الآداب، قسم الإعلام،

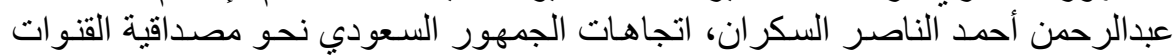

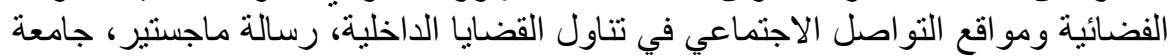

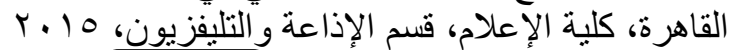




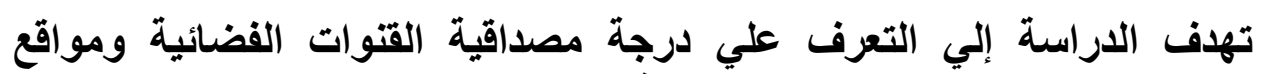

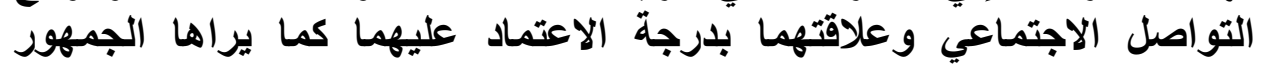

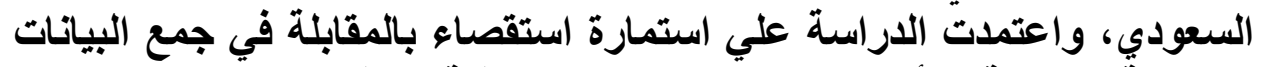

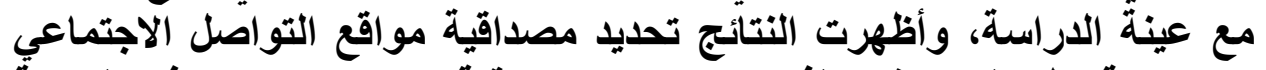

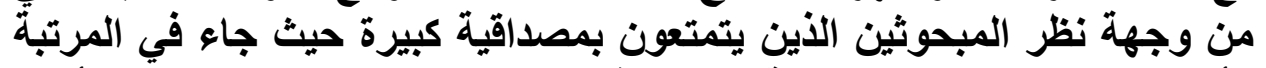

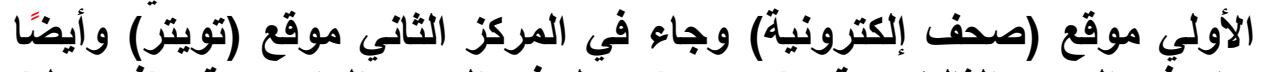

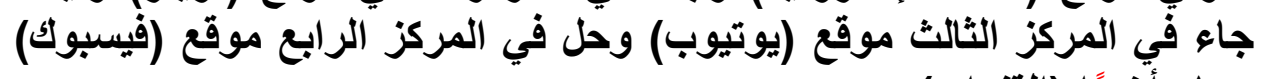

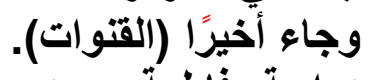
دراسة: فاطمة محمد صالحًا (') " العوامل المؤثرة علي مصداقية المادة الإخبارية

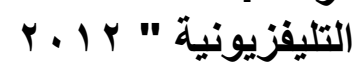

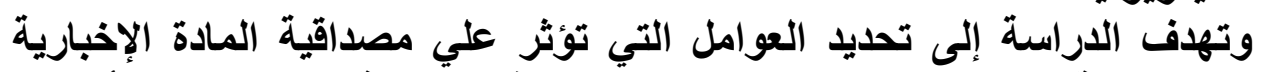

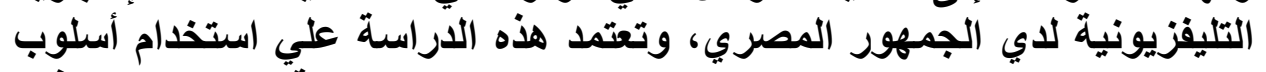

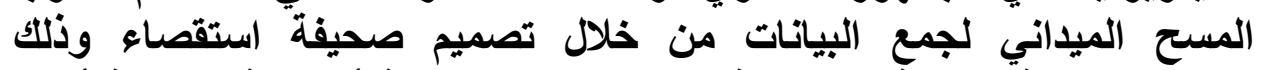

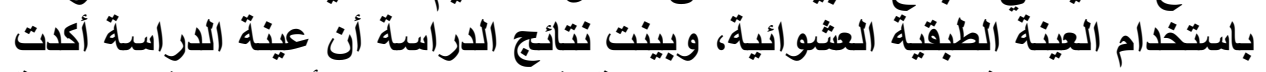

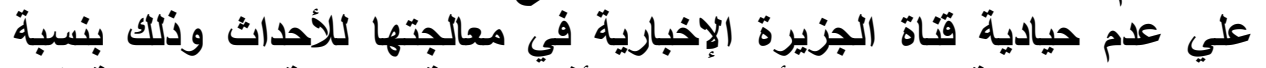

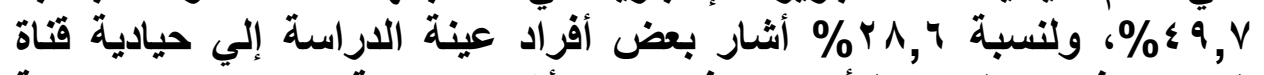

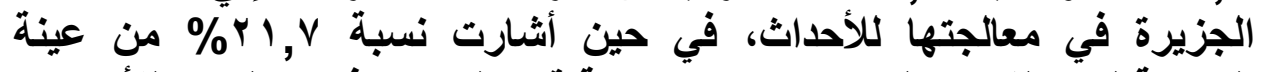
الاراسة لعدم القدرة علي تحليد مدي حيادية قناة الجزيرة في معالجتها للأحداث. عئ.

دراسة: وليد رشيد العبيدي(؟) "مستويات مصداقية الأخبار في القنوات العراقية

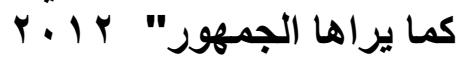
تهاف الداراسة إلي معرفة مستويات مصداقية الأخبار في القنوات التليفزيونية

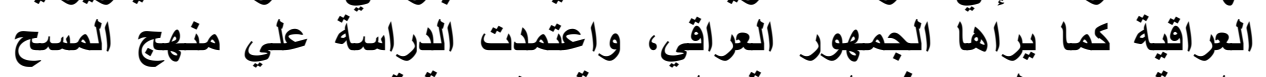

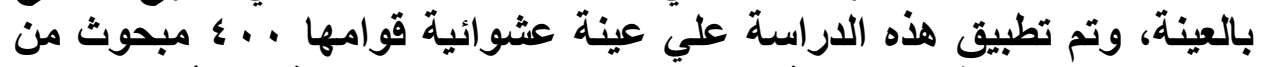

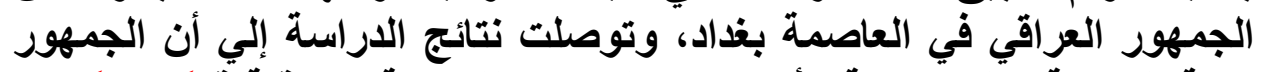

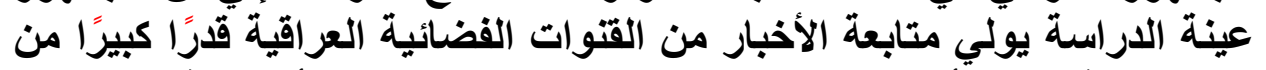

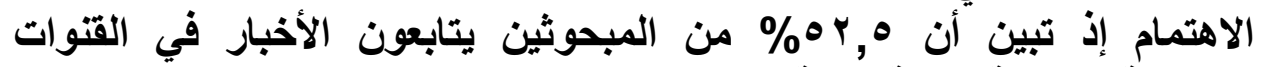
الفضائية العراقية بصفة دائمة .

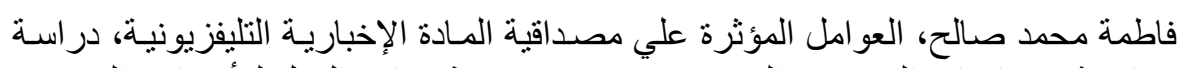

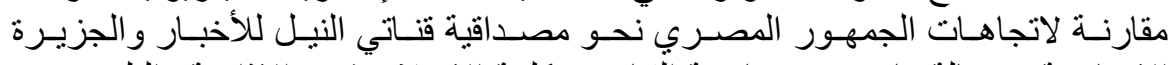

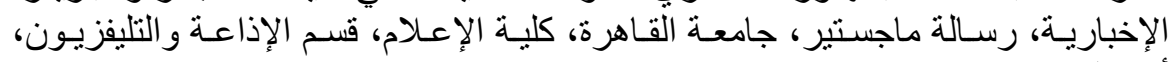

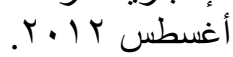

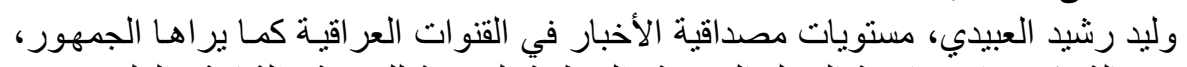

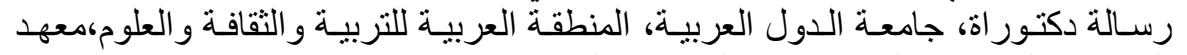

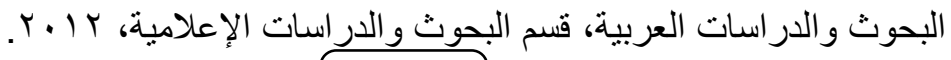


دراسة : Thomas B Christie , Andrew M Clark هدفت الاراسة إلي فهم ودراسة مصداقية وفاعلية راديو سوا في الولايات

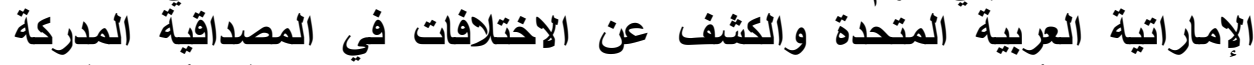

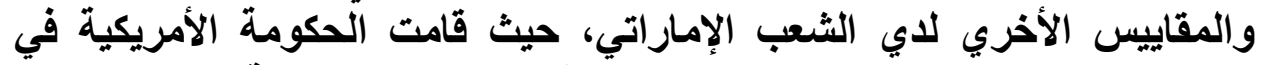

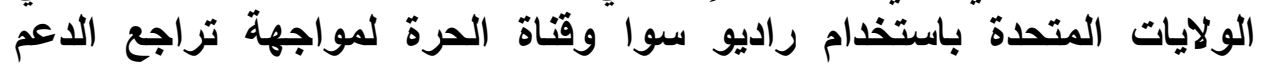

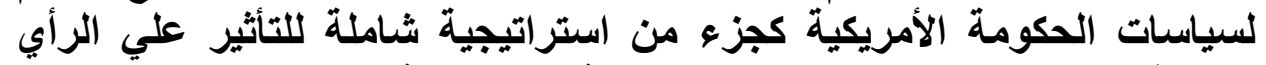

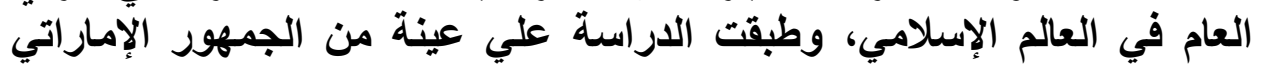

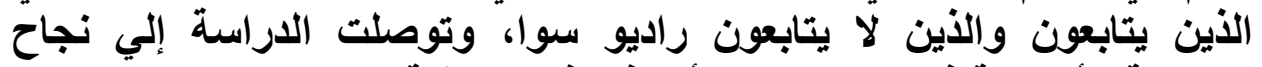

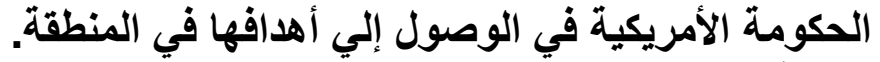

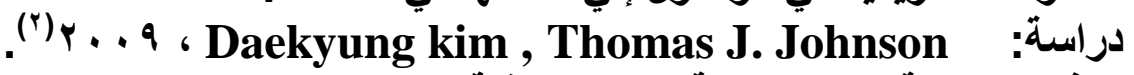

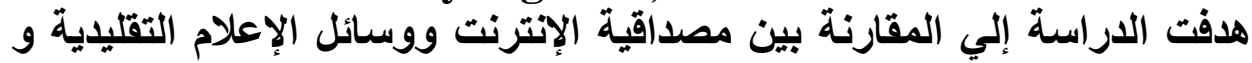

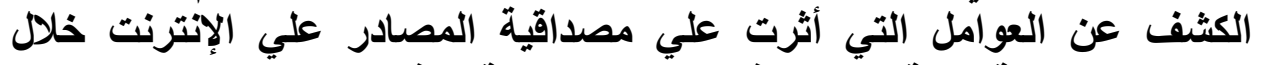

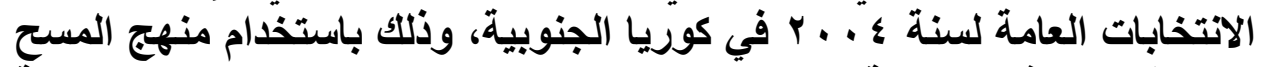

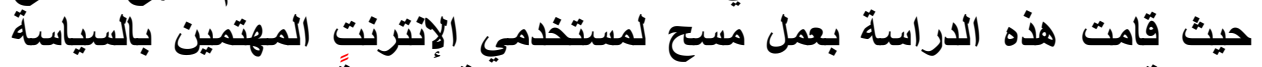

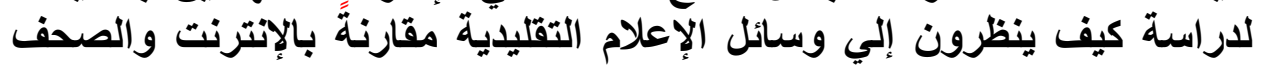

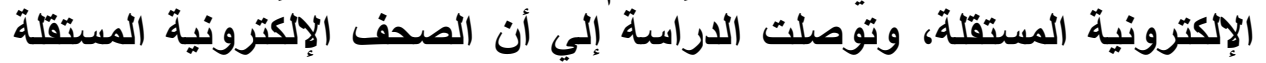

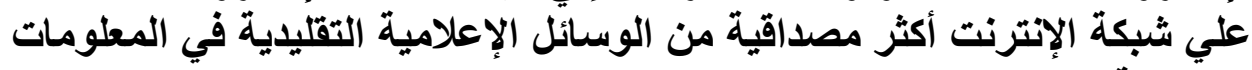

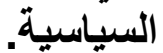

\section{نوع الدراسة ومنهجها:}

تنتمي هذه الدراسة إلي البحوث الوصفية، والتي تهذف إلي تفسير وتحليل

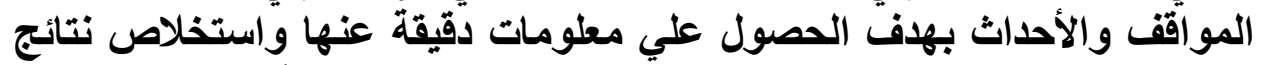

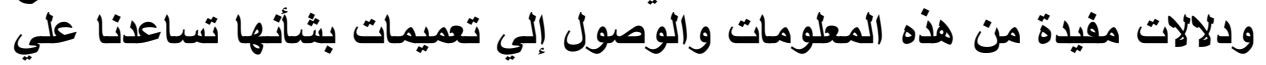
تفسير الظواهر التي تقوم بلدراستها.

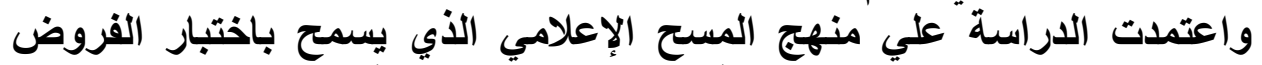

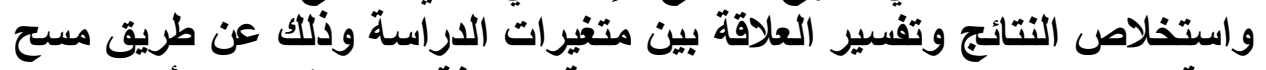

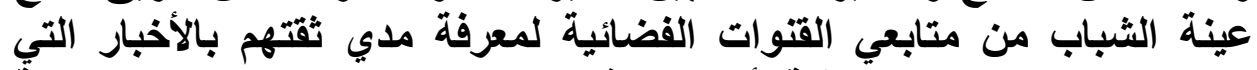

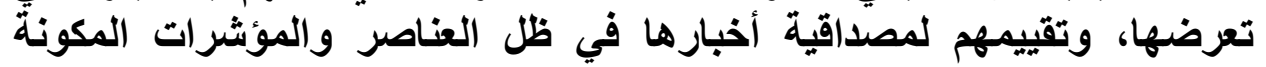

(1)Thomas B Christie , Andrew M Clark , Believe it or not: Understanding the credibility and effectiveness of Radio Sawa in the UAE, International Communication Gazette, vol.73 , no. 4,2011 ,pp 359-371

$\left({ }^{2}\right)$ Daekyung kim , Thomas J. Johnson, A shift in Media Credibility : Comparing Internet and Traditional News Sources in South Korea, International Communication Gazette, Volume 71 Issue4, June2009, pp 283-302 


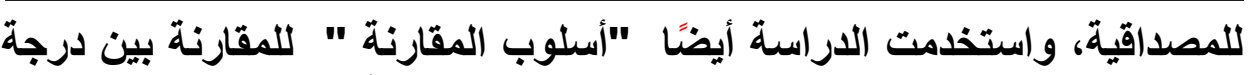

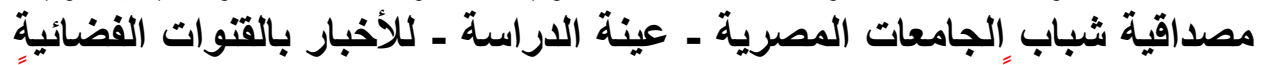

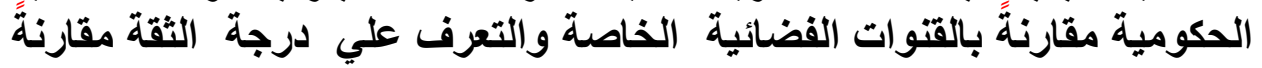

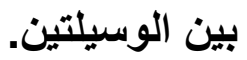

\section{مجتمع و عينة الدراسة : بينة}

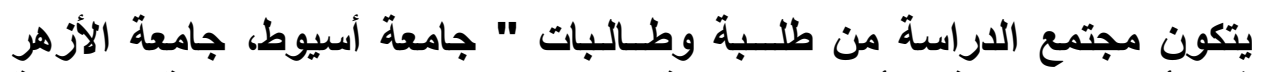

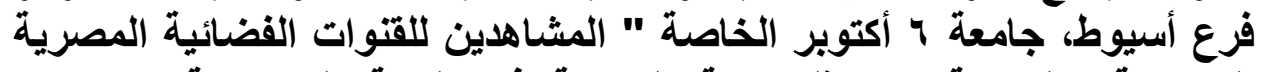

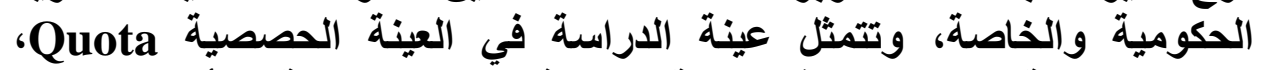

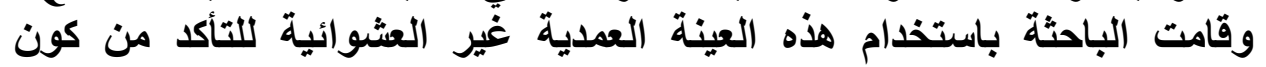
المبحوثين مشاهدين للقتوات الفضائية الحكومية والخاصة، كمئة كما إن العينة العينة الحصصية تسمح بتمثيل كافة الطو ائف حسب نسبتها الحقيقية في المجتمع عندما يتسع حجم مجتمع الاراسة.

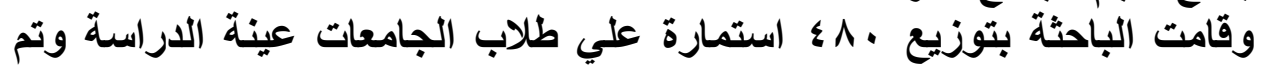

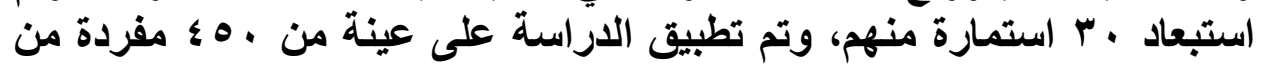

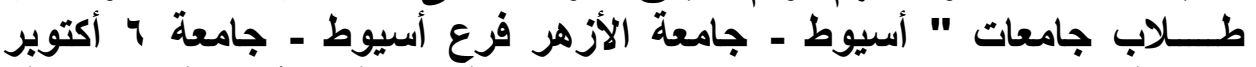

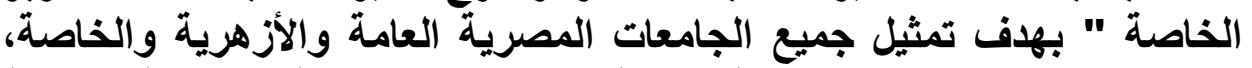

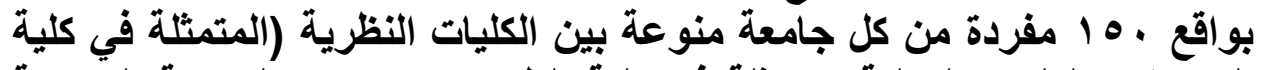

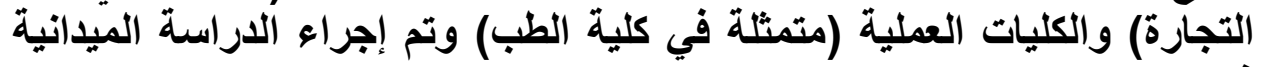

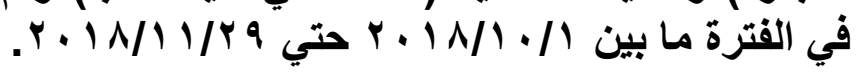

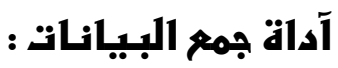

استمارة استبيان (استقصاء) يعتبر الاستبيان آداة أساسية ومباثرة من أدوات الدوات

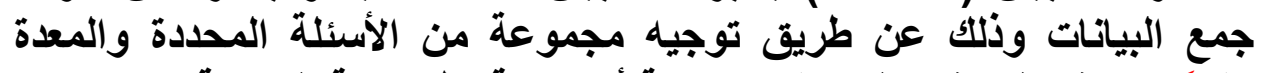

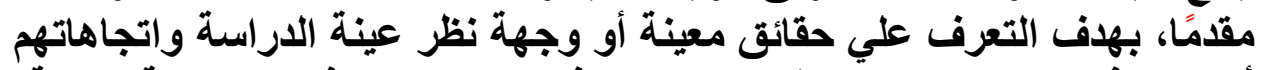

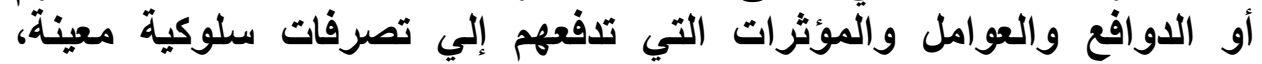

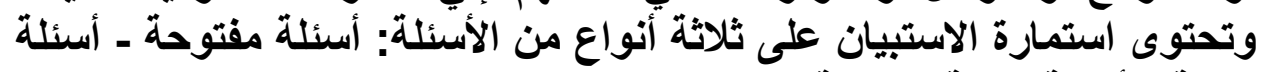
مغلقة - أسئلة مغلقة مفتوحة العئة

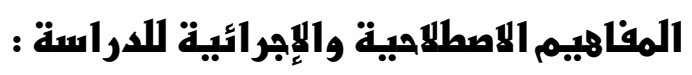

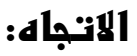

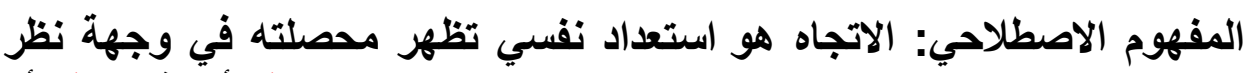

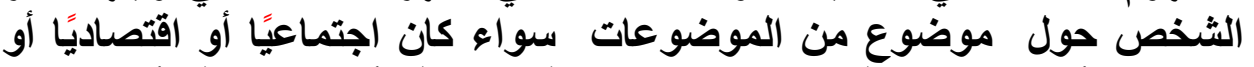

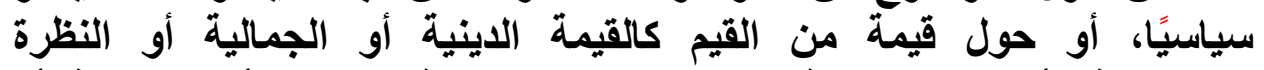

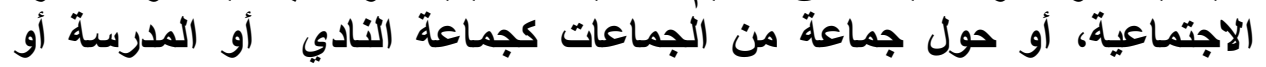

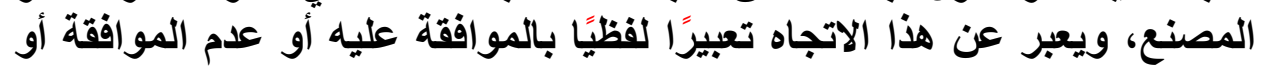


المحايدة، ويمكن قياس الاتجاه بإعطاء درجة للموافقة أو المعارضة أو

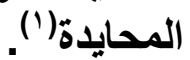

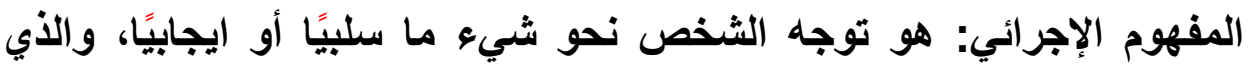

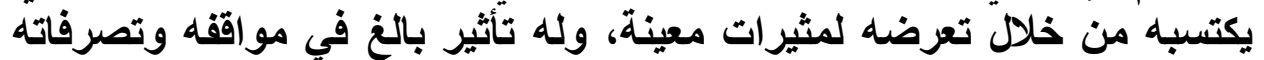
اليومبة.

\section{1الشباب الجامعيى:}

المفهوم الاصطلاحي: الطالب الجامعي هو الشخص المهات المسجل لنيل درجة علمية

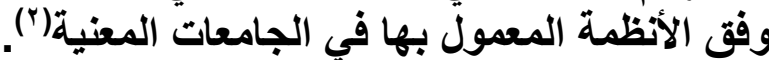

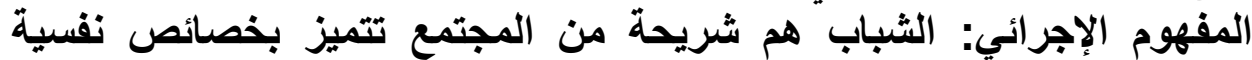

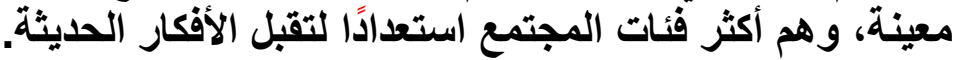

\section{المصداقبة:}

المفهوم الاصطلاحي: المصداقية هي مجموعة من العوامل والمعايير التي

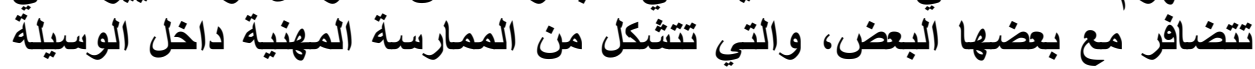

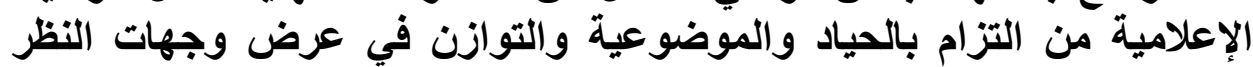

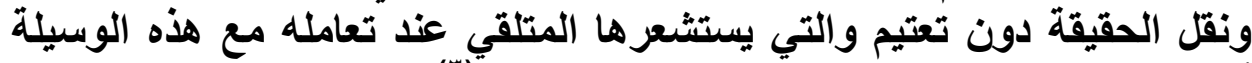

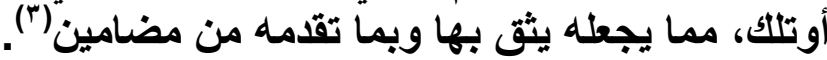

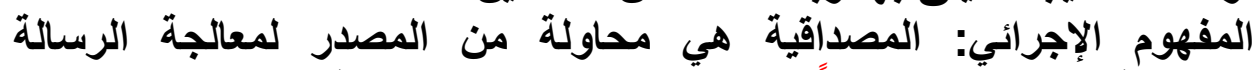

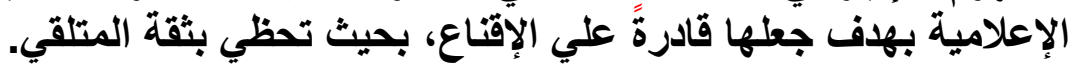
1فتبارات الصدق والثبات:

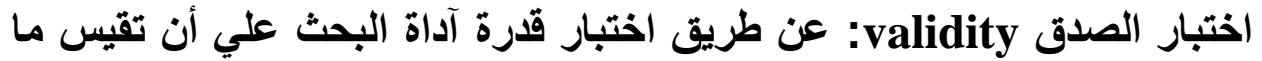

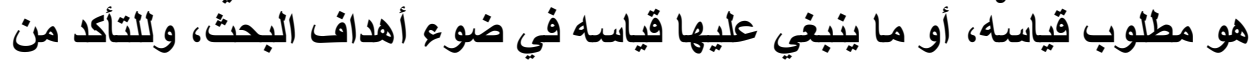

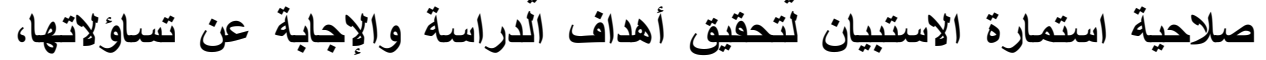

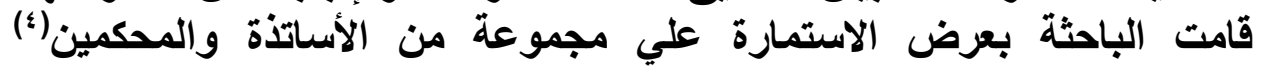

محمود السيد أبو النيل، علم النفس الاجتمـاعي، عربيًا وعالميًا، مكتبة الأنجلو المصرية،

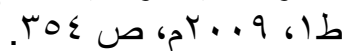

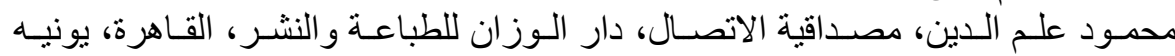

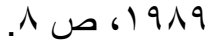

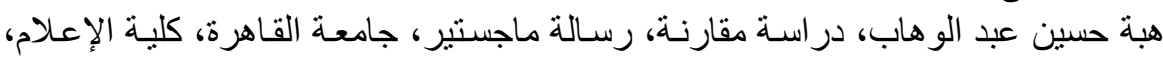

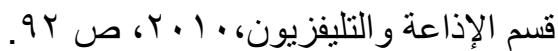

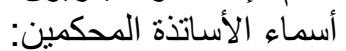

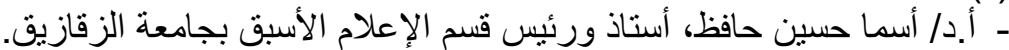

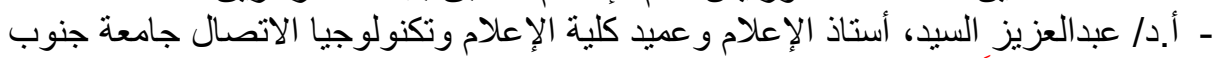
الو الو ادي سابقًا. ـ ـ أ.د/ غادة اليماني، أستاذ ورئيس قسم الإعلام بكلية الآداب، جامعة طنطا. 
المتخصصين للحكم علي صلاحيتها في قياس متفيرات الاراسة، وتحقيق أهدافها

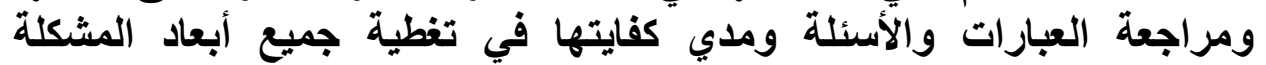

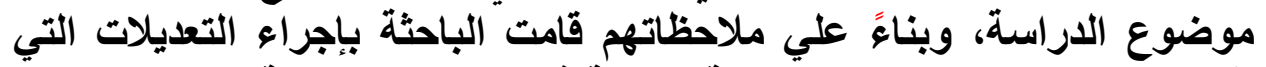
اقترحها المحكمون لتصبح الصحيفة صالحة في صورتها التهائة التهائية.

\section{افتنبار الثبات Reliability}

استخدمت الباحثة معادلة ألفا كرونباخ وهي معادلة تستخدم لإيضاح الماتبات المنطق العام

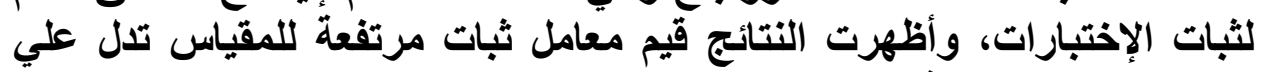

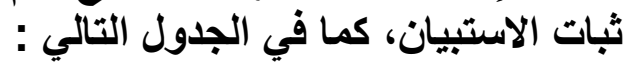
Alpha cronbach جدول رقم (1) ثبات الآداة باستخدام طريقة ألفا كرونبان method

\begin{tabular}{|c|c|c|}
\hline قيمة ( كرونباخ الفا ) & عدد العبار ات & المتغير \\
\hline$\cdot . \wedge \leqslant \mu$ & $\Lambda$ & الفضائية ثقة الثباب الجامعي في القتوات \\
\hline$\cdot . \Lambda \mu r$ & $r$. & مؤشرات مصداقية القتوات الفضائية \\
\hline$\because . \wedge \diamond \wedge$ & צ Y عبارة إيجابية & سمات الأخبار التي تعرضها القتوات \\
\hline$\cdot . \mathrm{ATY}$ & ـ צ Y عبارة سلبية & الفضائية \\
\hline
\end{tabular}

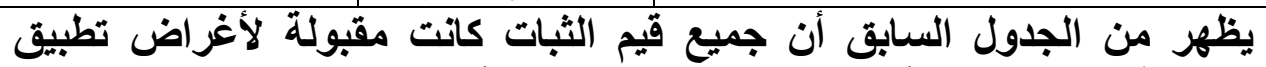

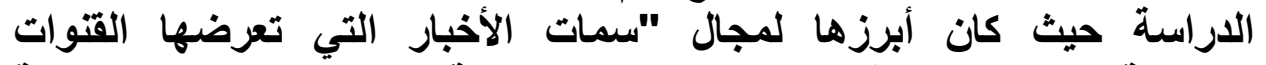

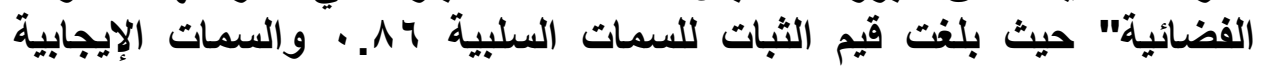

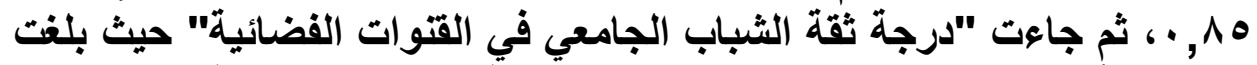

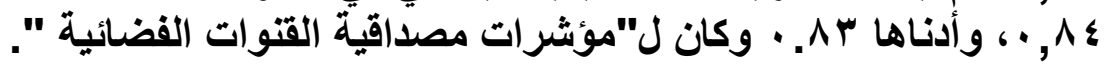

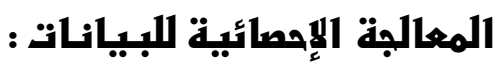

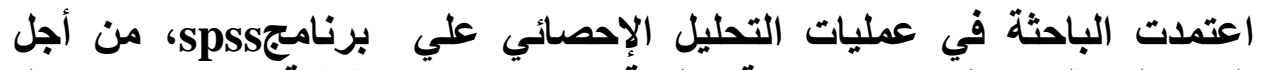

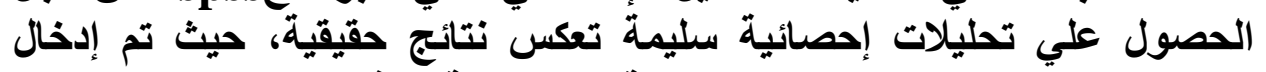

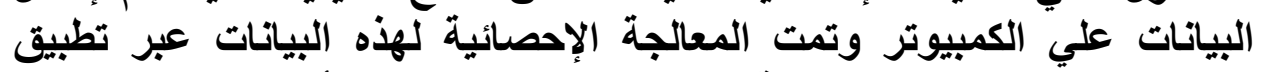

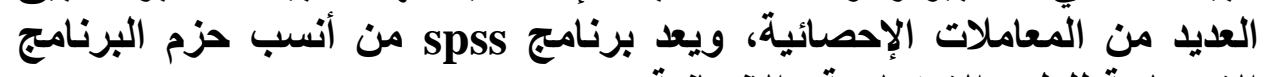
الإحصائية للعلوم الاجتماعية الإحماتية والإنساتية.

ـ ـ أ.د/ محمود علم الدين، أستاذ الصحافة بكلية الإعلام جامعة القاهرة.

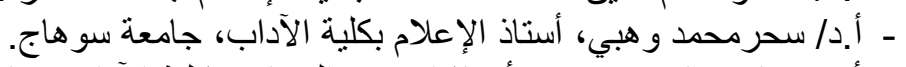

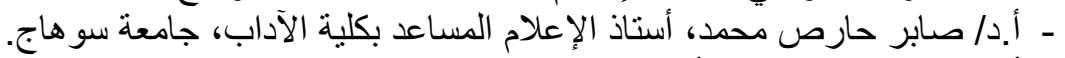

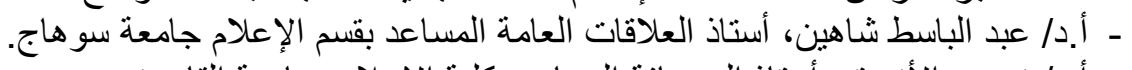
- أ.د/ نرمين الأزرق، أستاذ الصحافة المساعد بكلية الإعلام، جامعة القاهرة. 


\section{الإطار النظري}

أولاً: مصداقية الأفبار فيى وسائل الإعلام:

\section{مفهوم المصداقية : (Credibility)}

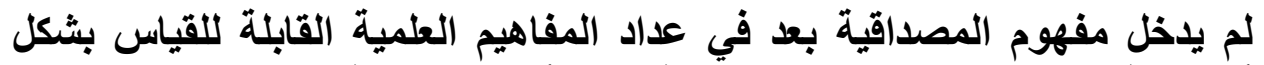

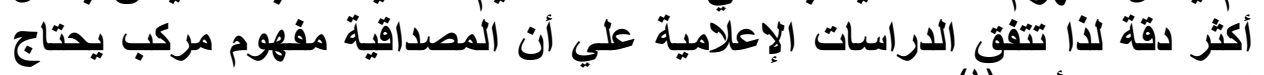

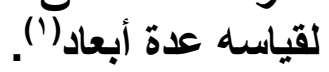
و ظهر الكثير من الاختلافات حول مفهوم مصداقية وسائل الإعلام النظري

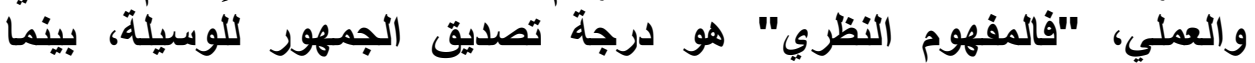

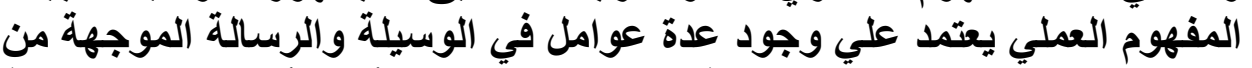

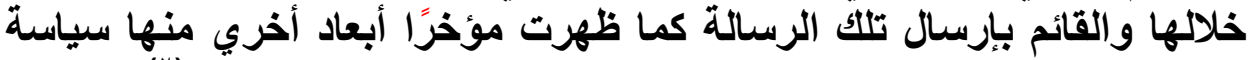

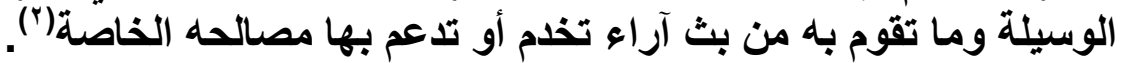

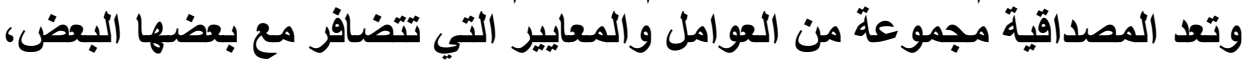

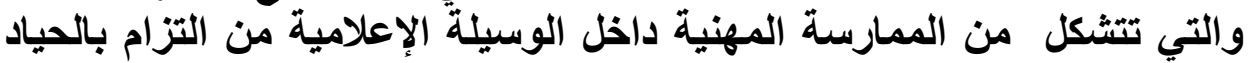

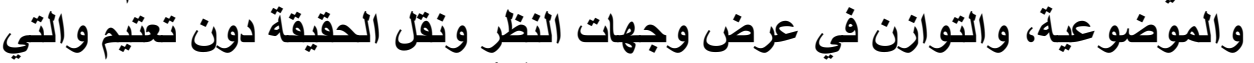

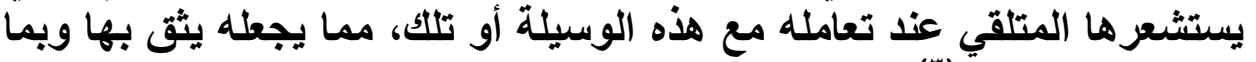

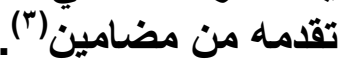

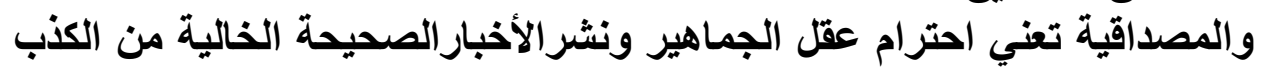

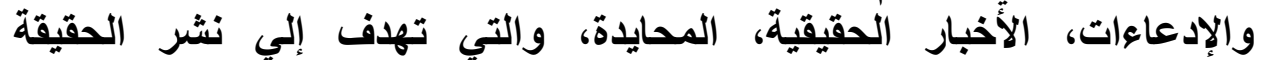

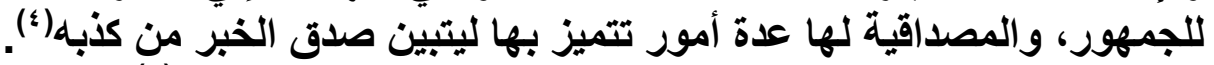

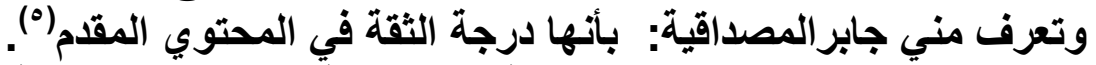

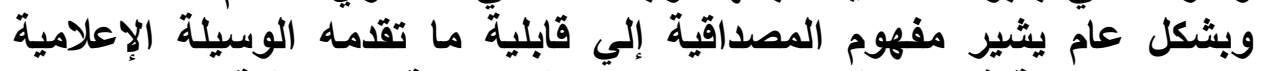

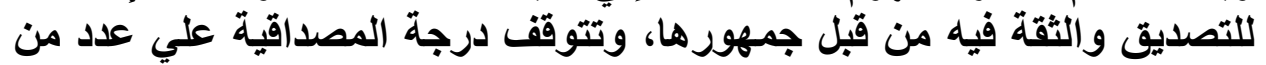

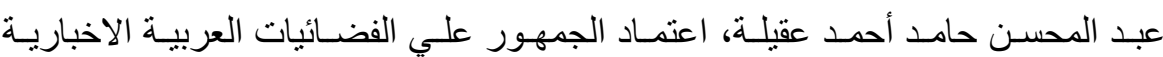

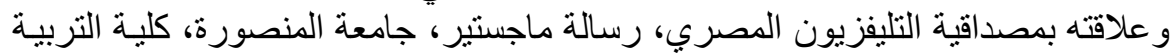

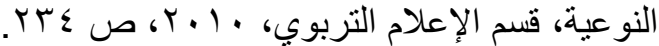

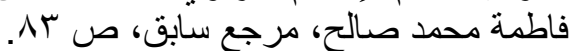

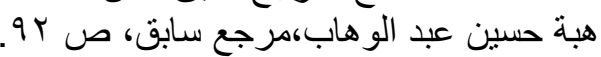

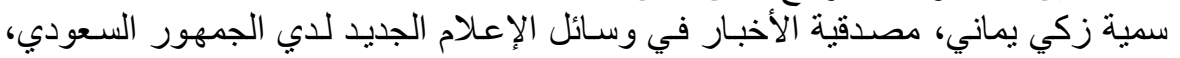

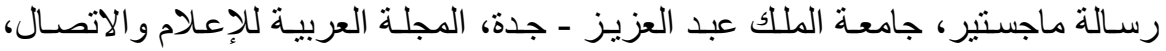

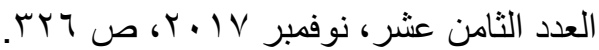

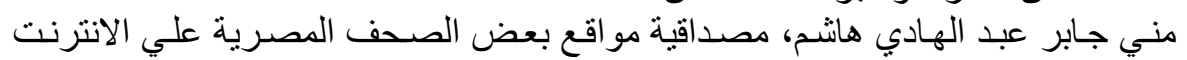

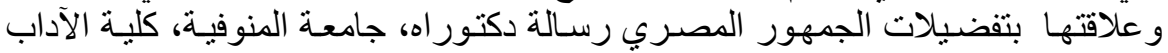


العوامل يرتبط بعضها بالرسالة الإعلامية أو القائم بالاتصال، ويرتبط البعض الآخر بالوسيلة الإعلامية ذاتها، بالرئال

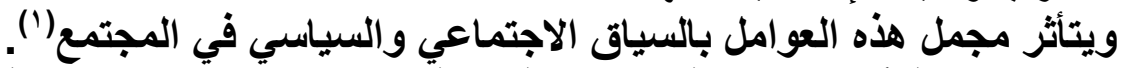

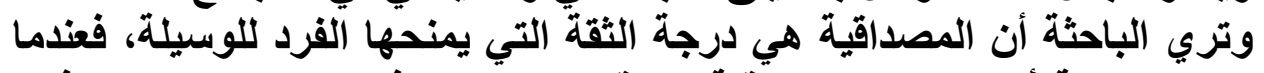

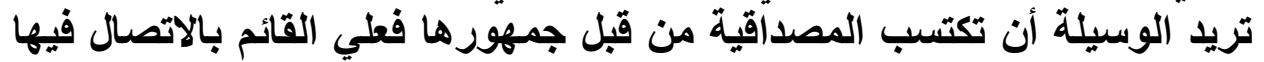

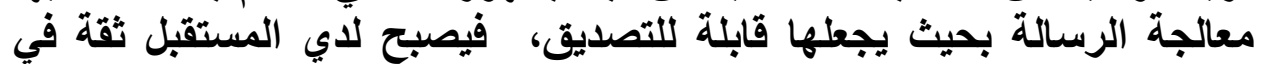

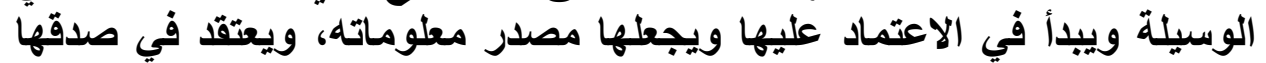

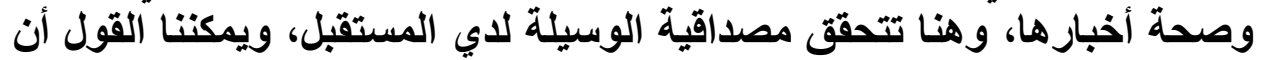

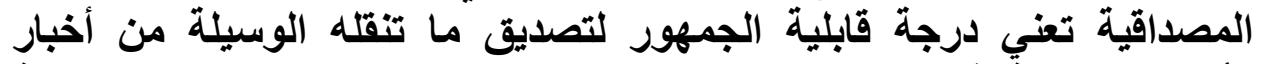

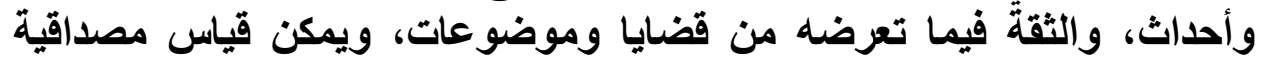

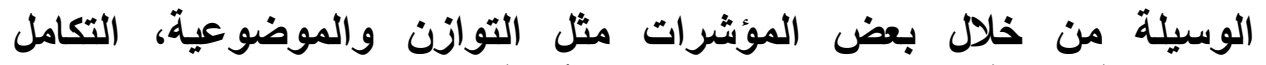

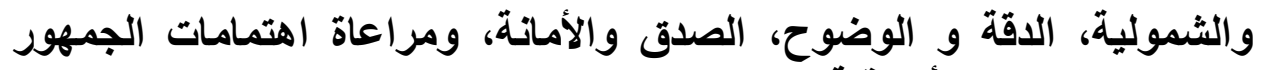
والالتزام بالمعايير الأخلاقية.

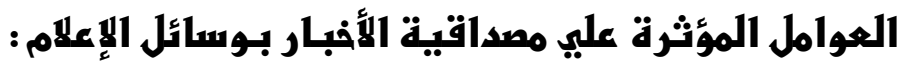

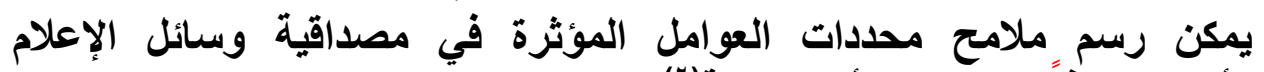
وأخبارها وفقًا لمحاور التأثير التالية(†):

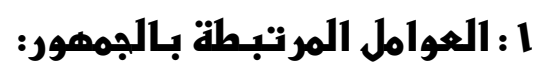

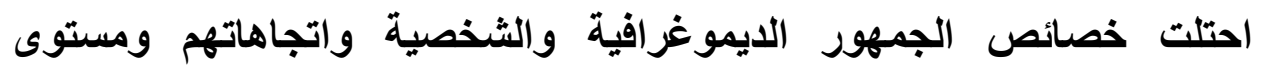

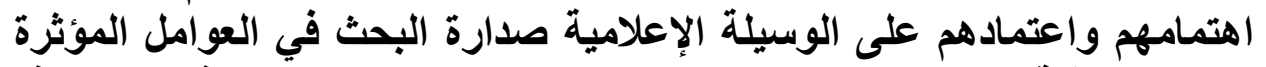

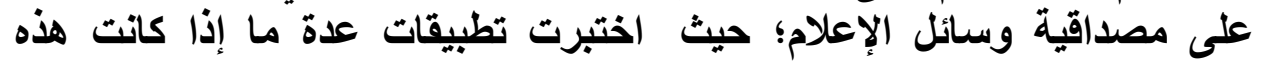

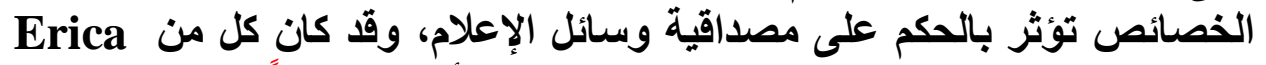
Qingwen Dong\&WeintraubAustin

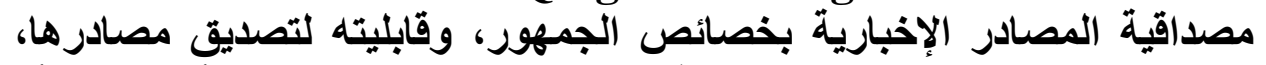

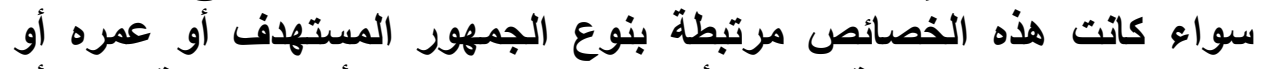

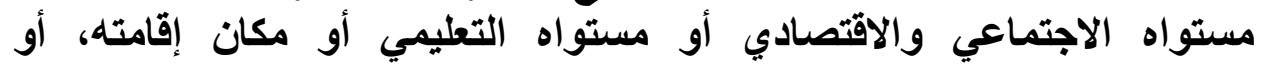

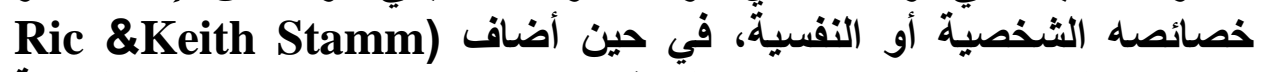
(Dube المطروحة من جهة، واتجاههم نحو هذه القضية إيجابًا أو سلبًا، وقبولاً أو نفورًا

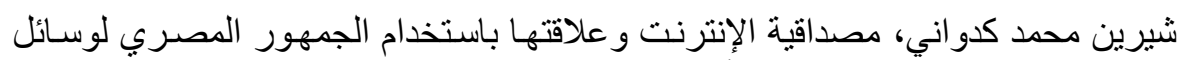

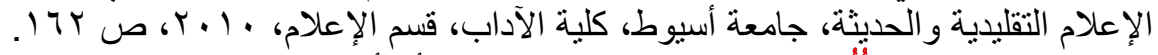

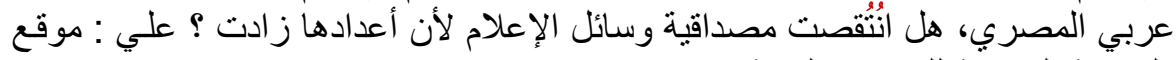

Available at : http://www.spra-

sy.com/website/?more=3688\&category $\_$id $=124(16 / 3 / 2017)$

พч^ 
من جهة أخرى، حيث أشارت التطبيقات إلى أن التطرف في الاتجاه وتقديرات

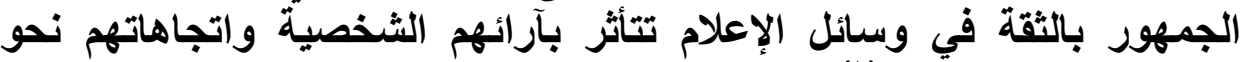

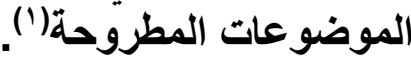

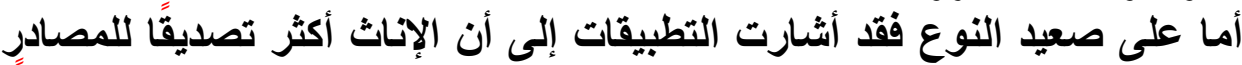

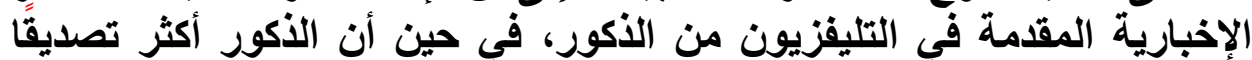

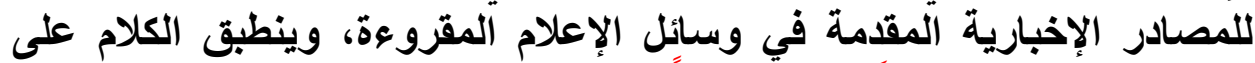

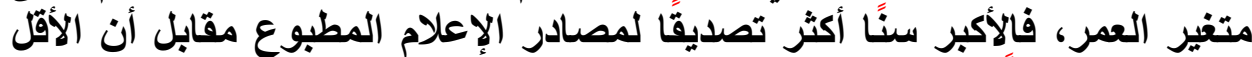

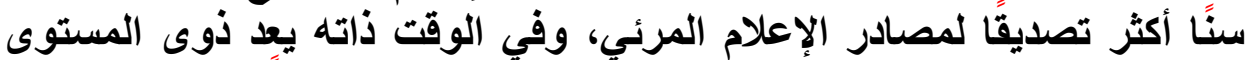

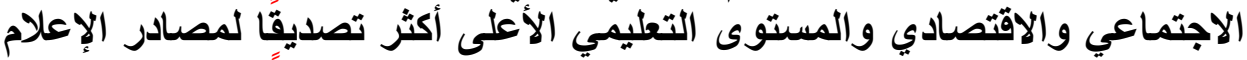
المقروء من نظرائهم ذوي المئمي والميتويات المنخفضة الأكثر تصديقًا لمصادر الإعلام المصام

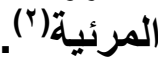
ويجب علي القائم بالاتصال دراسة الجمهور الأي يوجه إليه رسالته رئله ومعرفته

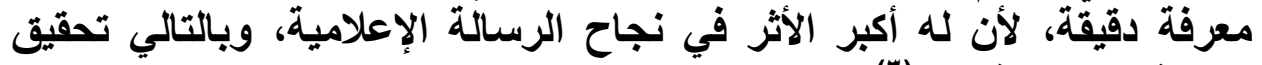

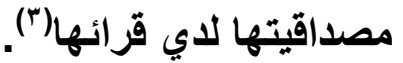

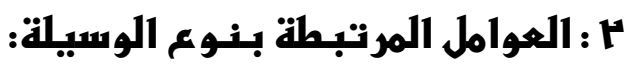

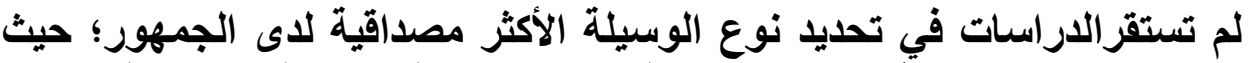

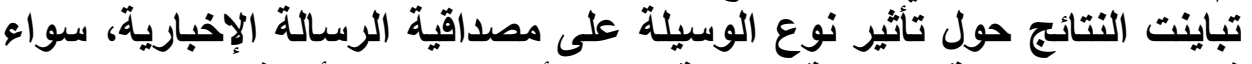

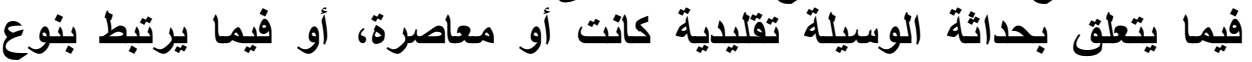

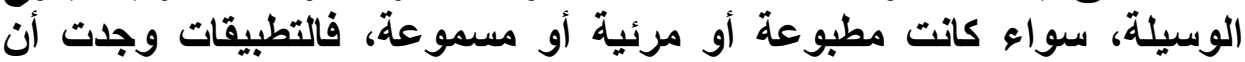
المصادر المستقاه من التليفزيون أكثر مصداقية من مصادرة الصدف الصف كقاعدة لا

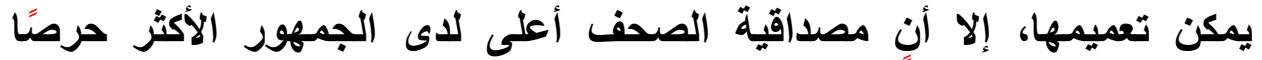

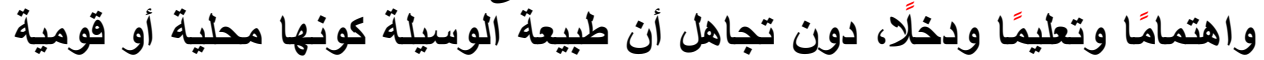

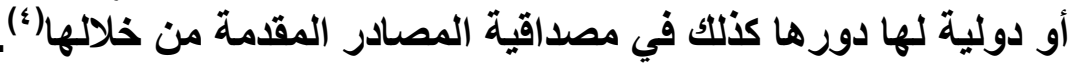

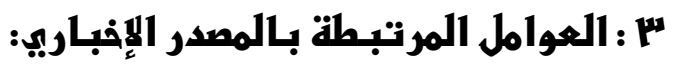

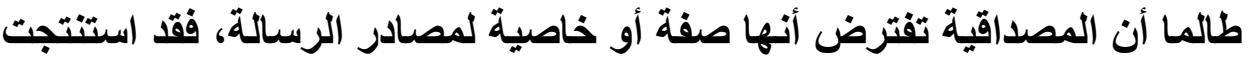

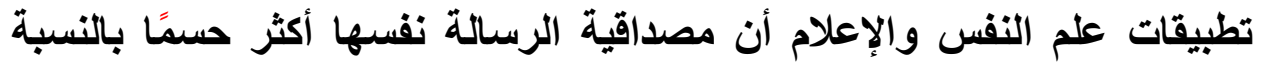

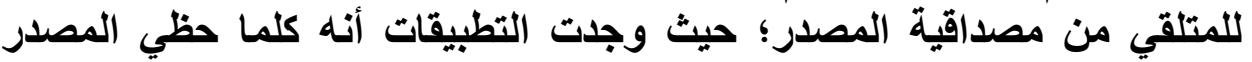

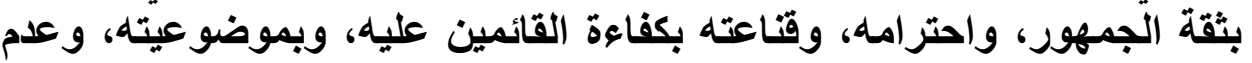

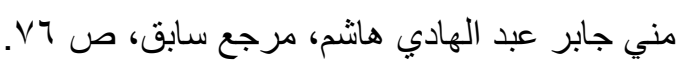

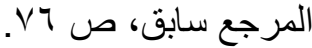

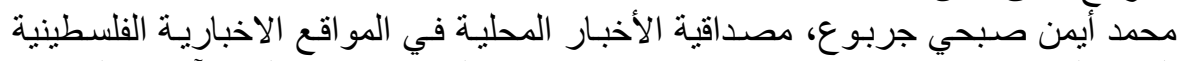

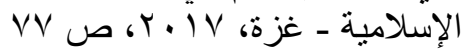

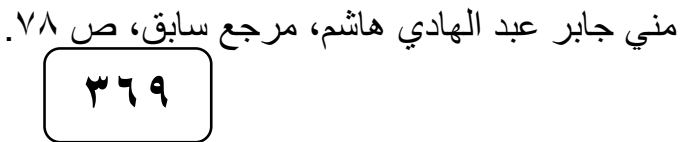

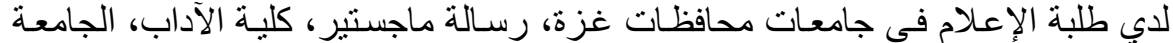


انحيازه، واكتمال عناصره الإخبارية كلما ازدادت الثقة والمصداقية بهاه،

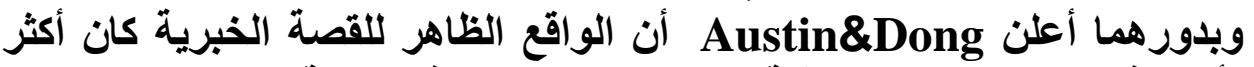

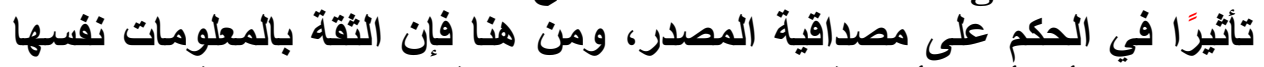

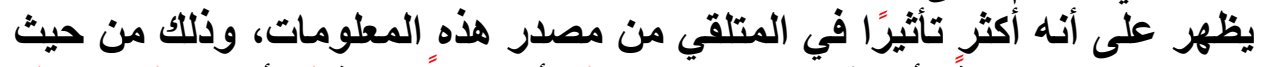

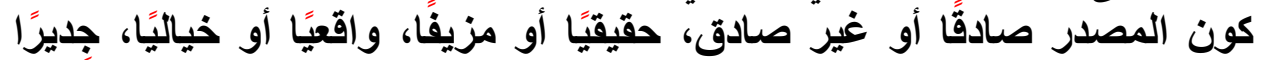

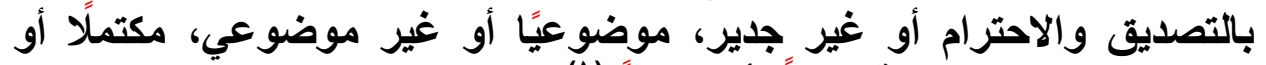
ناقص الغناصر الإخبارية، عادلًا أو متحيزًا (')

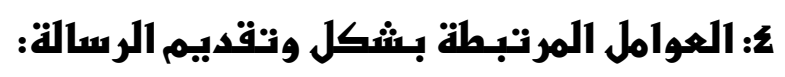

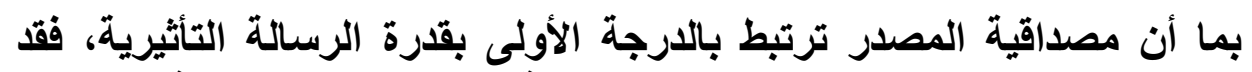

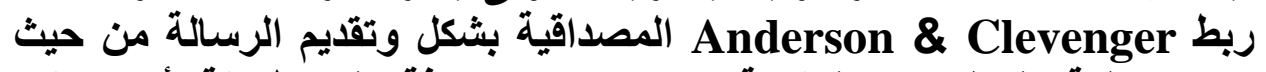

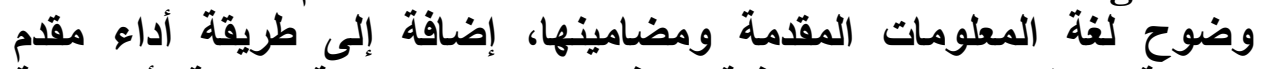

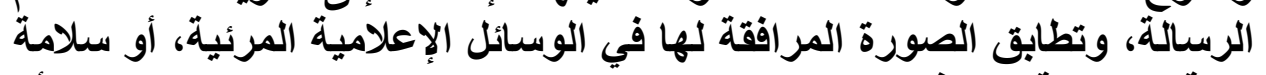

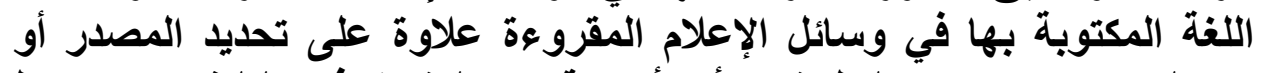

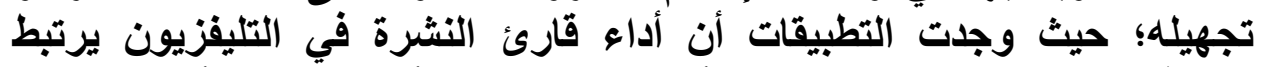

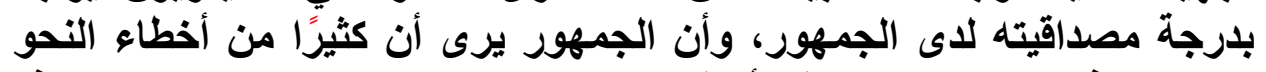

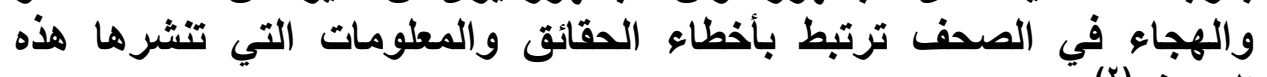

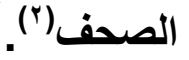

\section{0 : العوامل المرتبطة بطبيعة القضية المتناولة وأهميتهما:}

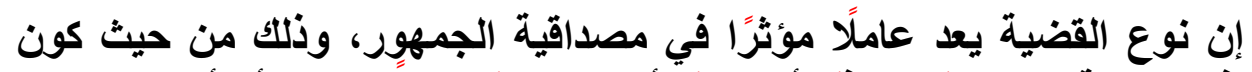

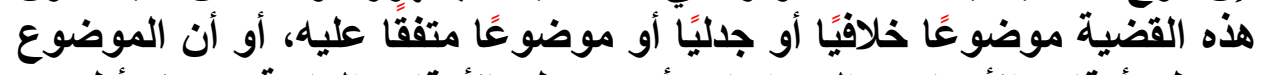

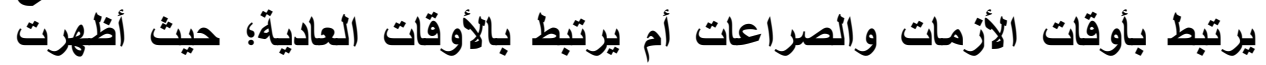

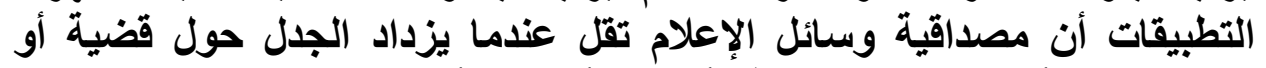

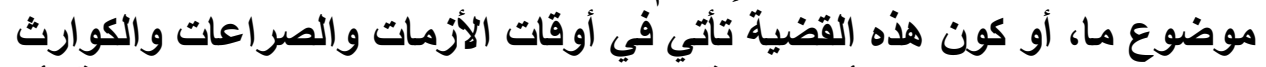

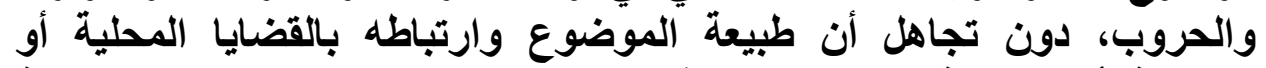

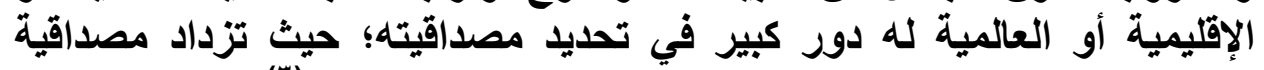

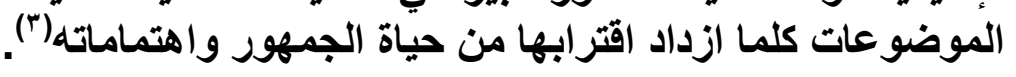
مقاييسر المصداقية : باتردئ بالرغم من اتفاق الباحثين علي أن مفهوم المصداقية مفهوم متعدد الأبعاد، إلا أن

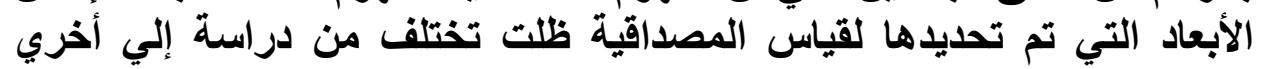

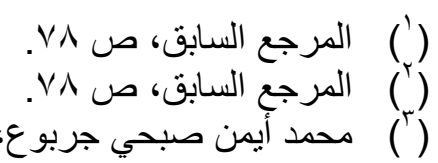

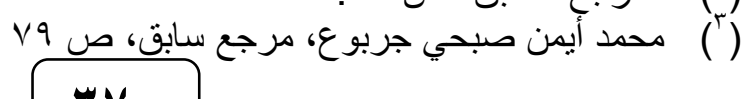

$$
\begin{aligned}
& \text { rV. }
\end{aligned}
$$




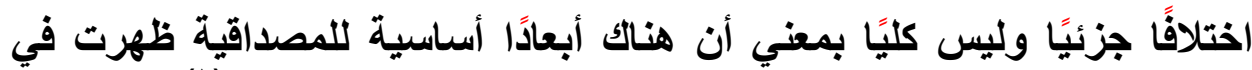

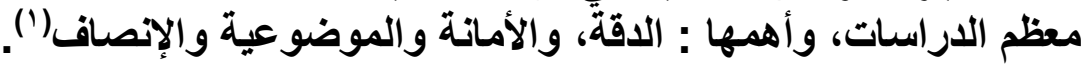

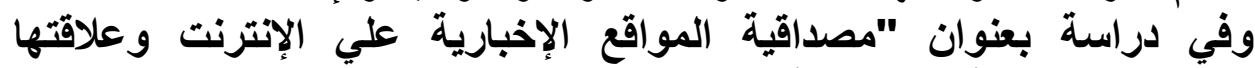

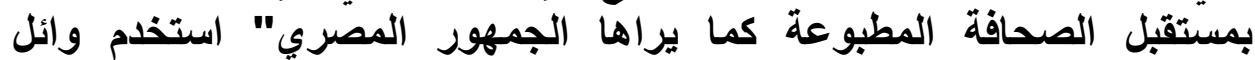

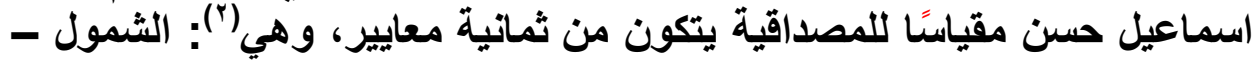

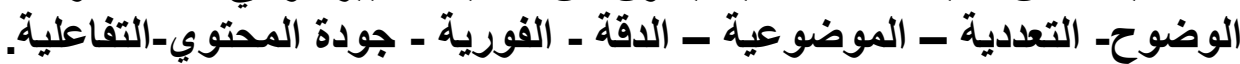
واستخدم عبد المحسن حامد في دراسته مجموعة من الأبعاد التي استخدمتها

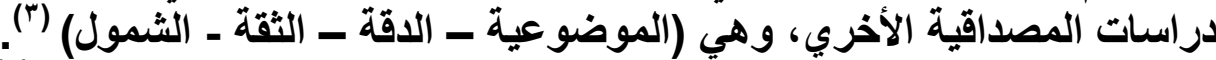

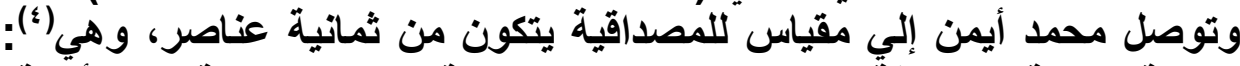

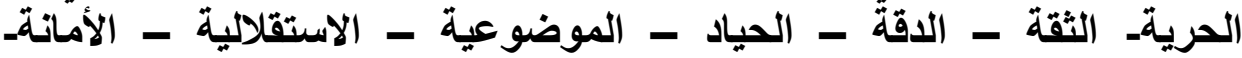
الشمولية.

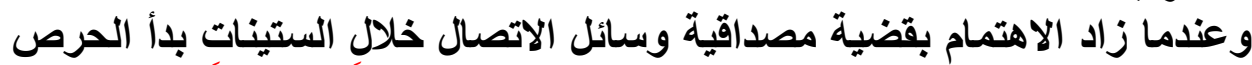

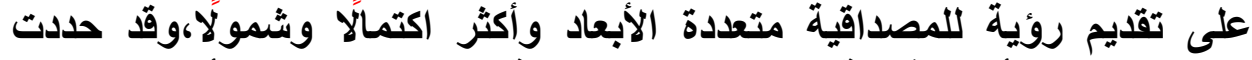

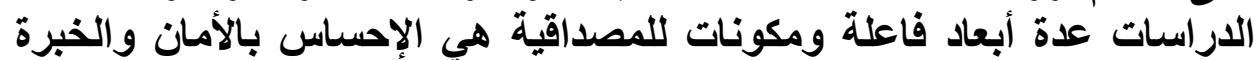

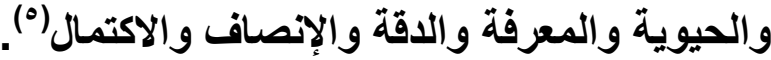

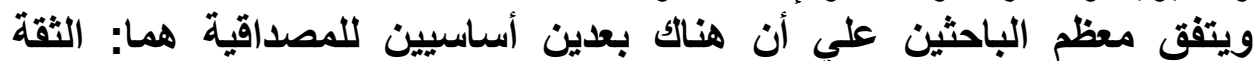

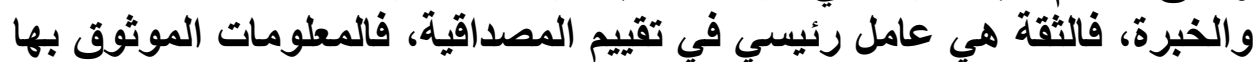

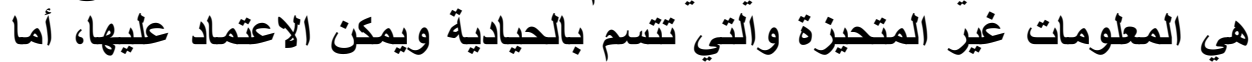

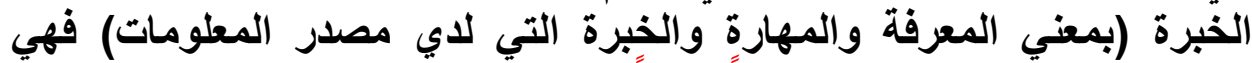

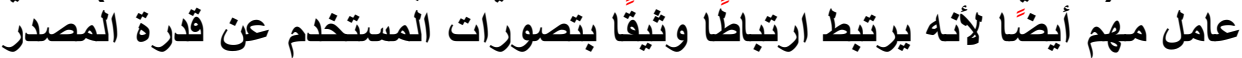

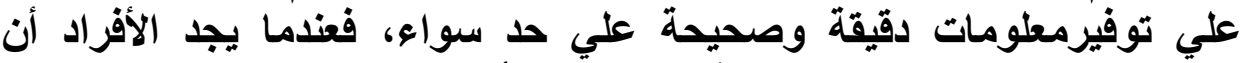

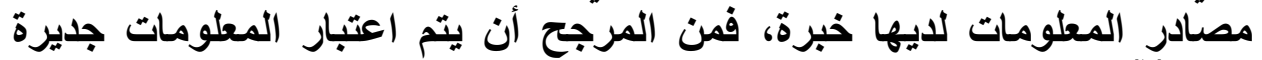

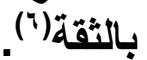
والمقياس الأي استخدمته الباحثة في هذه الدراسة يتكون من العناصر التالية : - الفورية والحالية في تغطية الأخبار. - الدقة في نقل الأخبار.

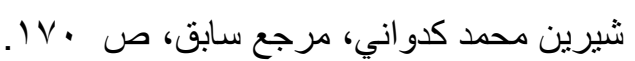

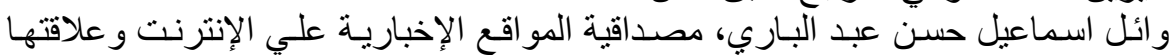

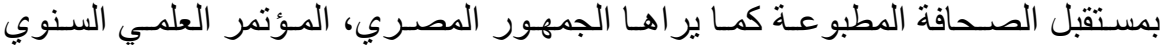

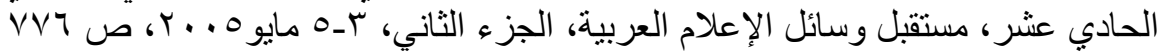

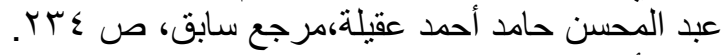

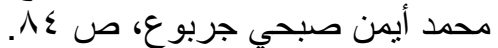
غادة عبد التواب الّيماني، مصداقية الأخبار المحلية في الصحف الصف والمو اقع الإخبارية، بحث

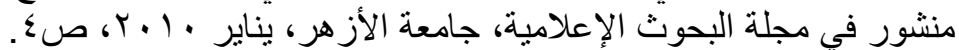

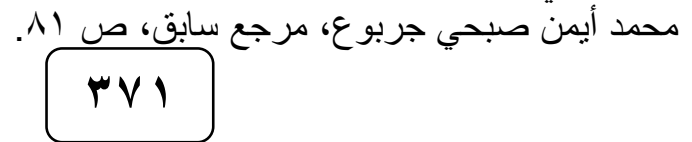




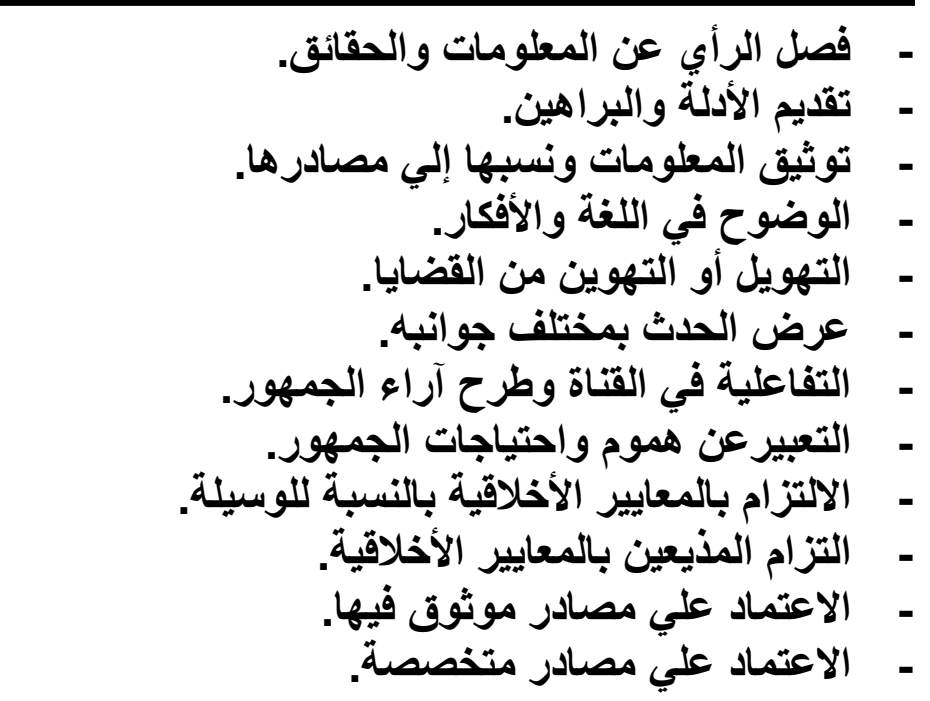

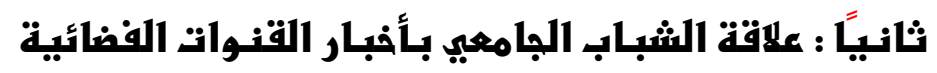

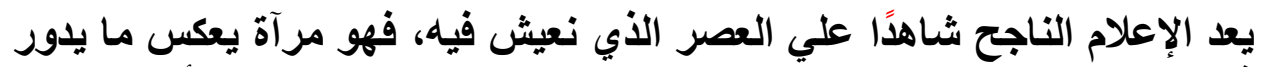

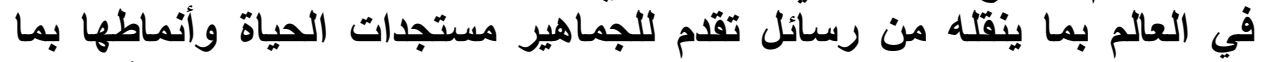

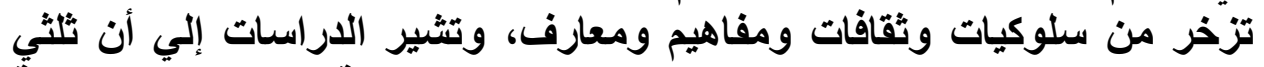

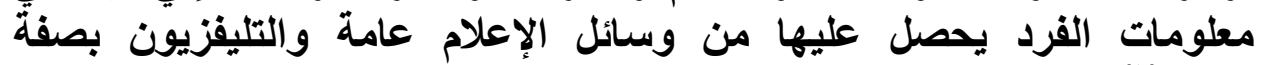

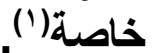
وفي عصرنا الحالي يشهر عالم الاتصالات تطورًا هائلًا أدي إلي هيمنة الإعلام

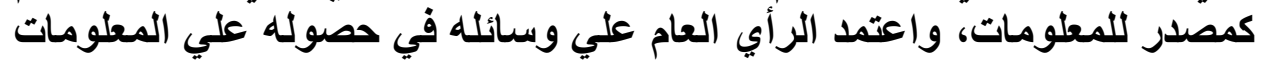

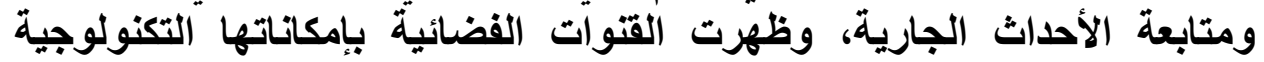

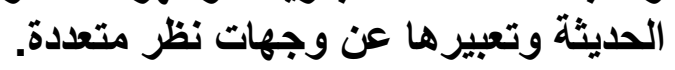

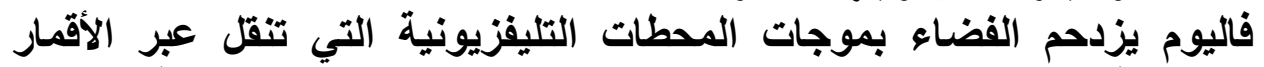

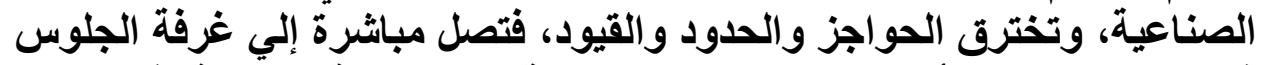

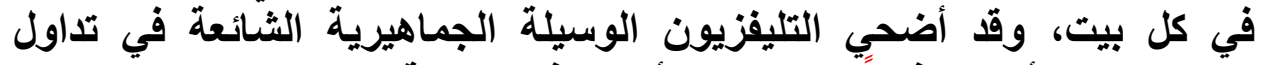

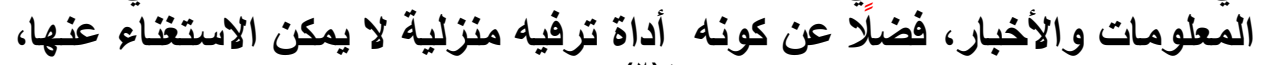

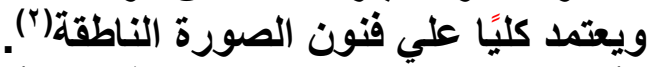

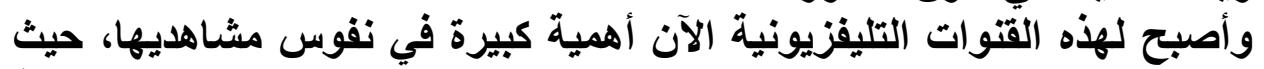

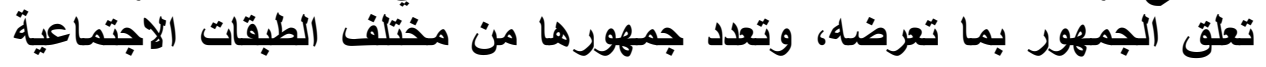

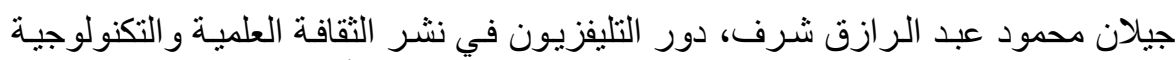

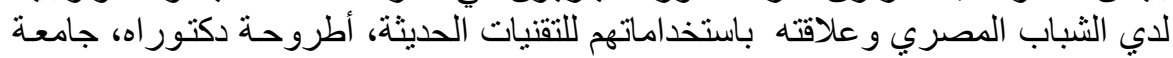

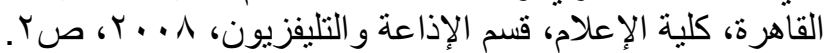

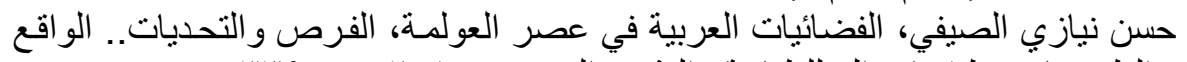

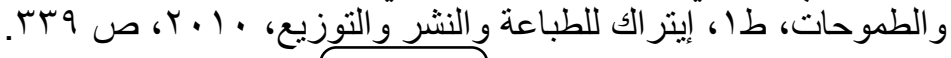


والمستويات الثقافية، فالقتوات الفضائية التليفزيونية تخاطب كل الفئات، وتوجه

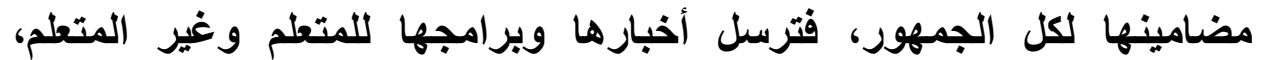

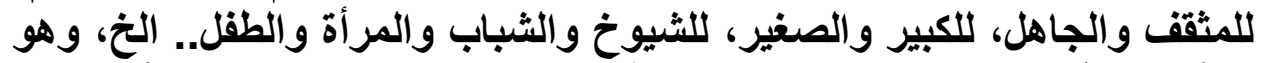

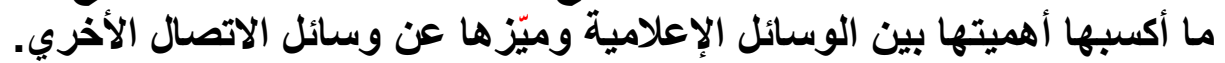

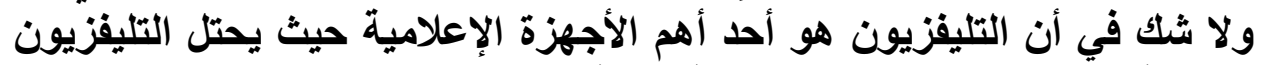

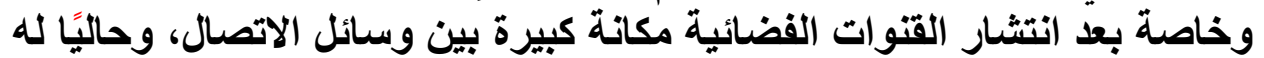

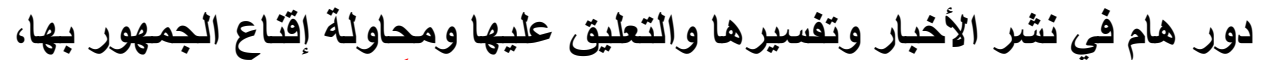

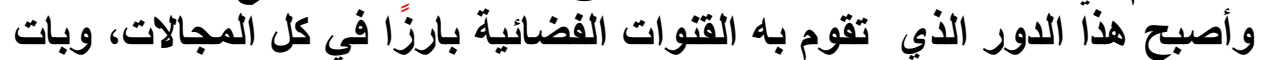

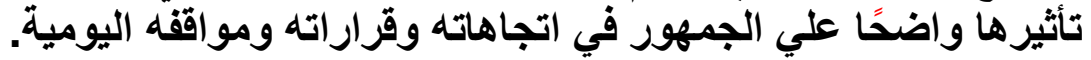

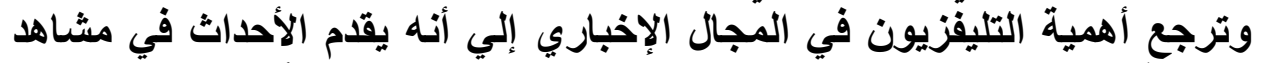

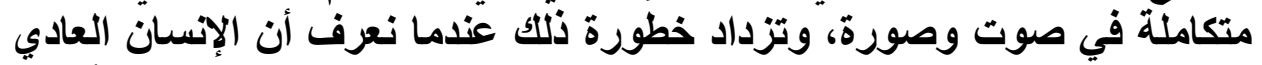

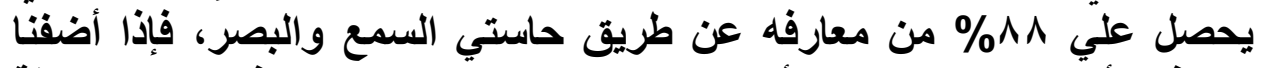

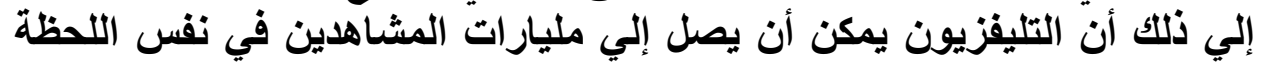

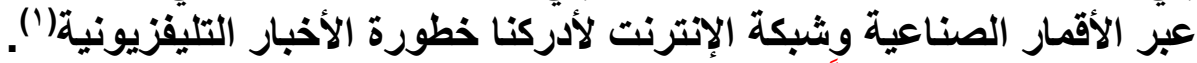

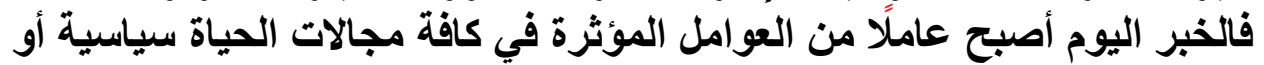

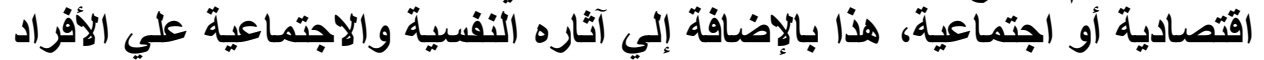

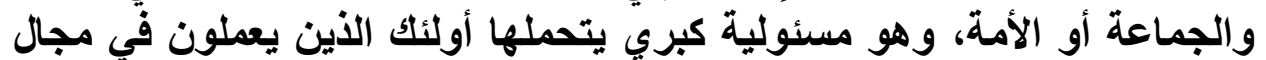

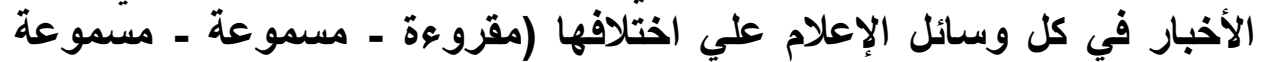

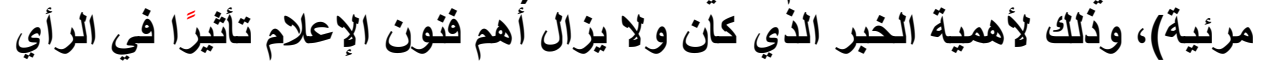

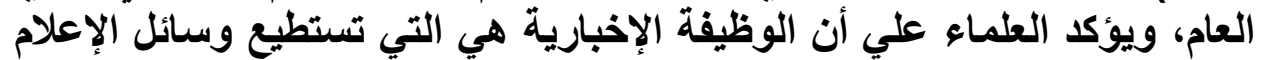

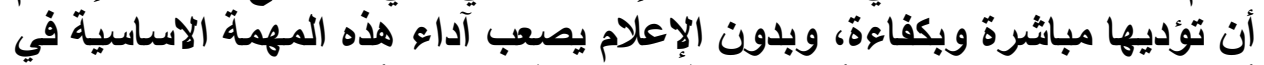

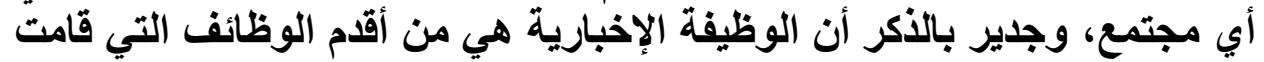

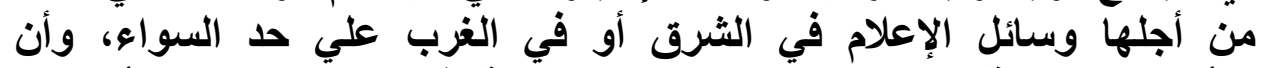

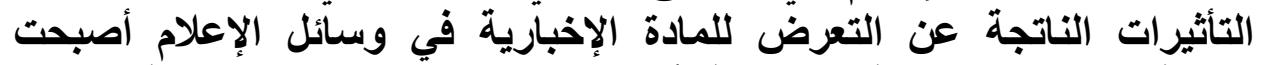

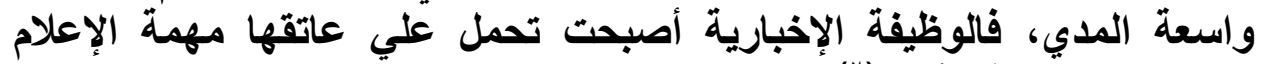

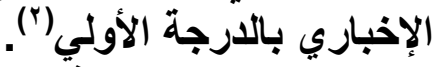

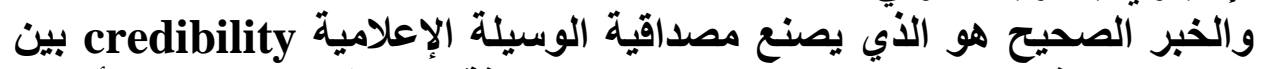

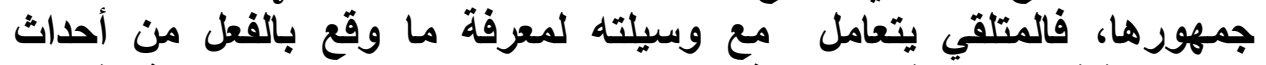

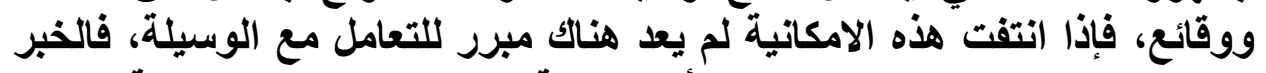
الصحيح الصادق هو مبرر وجود أبي وسيلة إعلام جادة تدرك مبك حقيقة دورها

عاطف عدلي العبد، الإعلام و المجتمع : الأسس النظرية و النماذج التطبيقية، القاهرة : دار

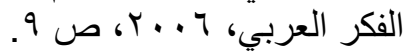
عزيزة عبده، الإعلام السياسـي و الر أب العـام في در اسـة ترتيب الأولويـات، دار الفجر ، 
الاجتماعي وتعي خطورة مسئوليتها إزاء جمهورها، إن من الأسئلة الكبيرة

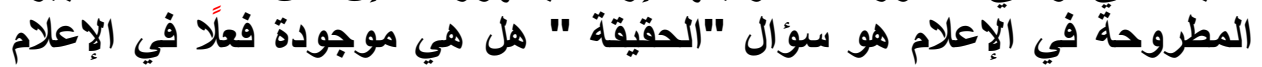

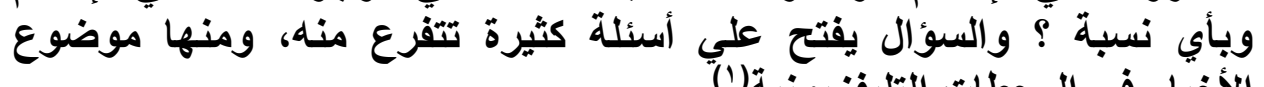
الأخبار في المحطات التليفزيونية)(').

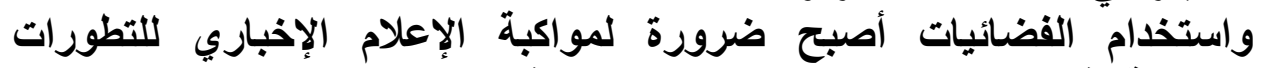

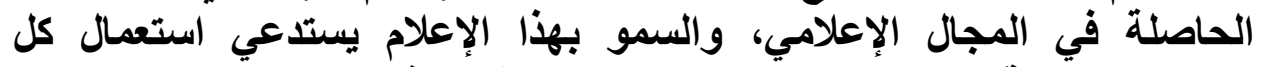

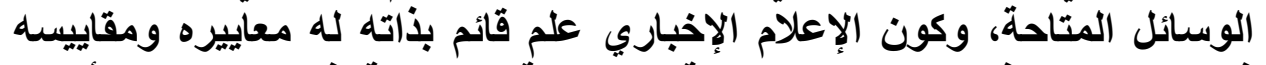

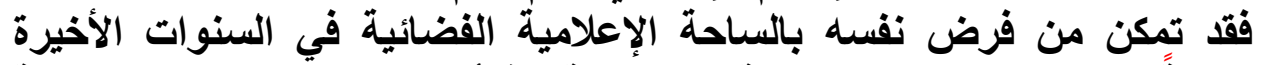

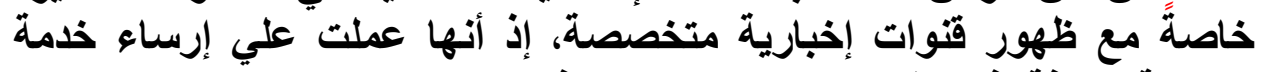

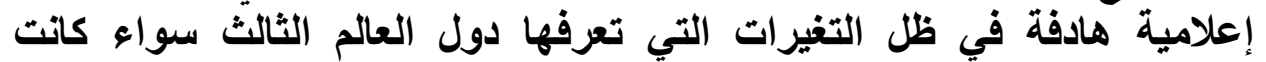

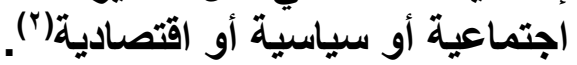

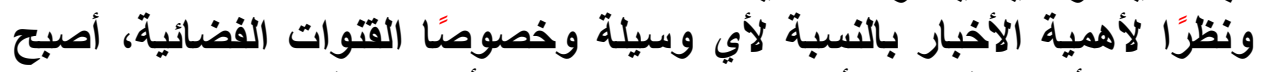

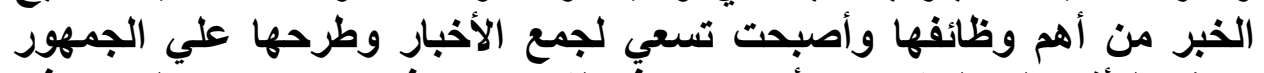

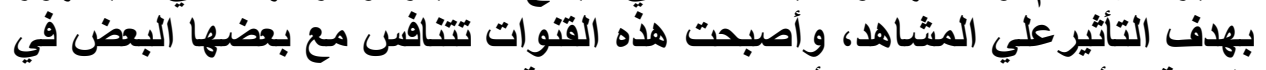

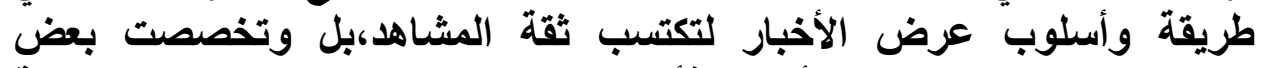

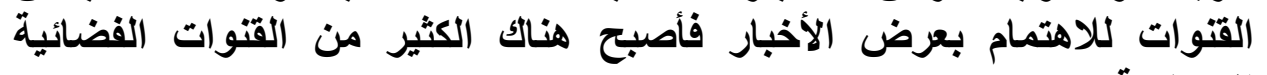

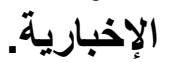

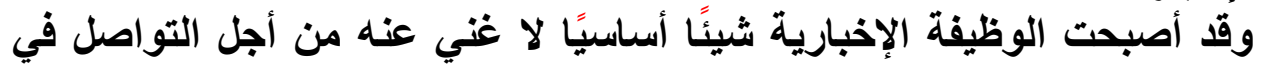

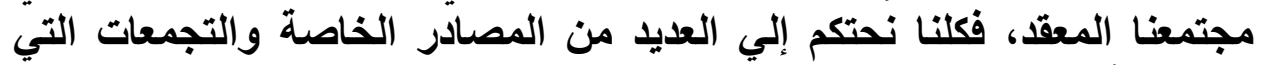

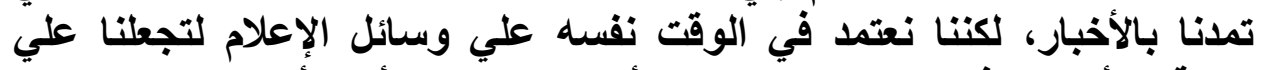

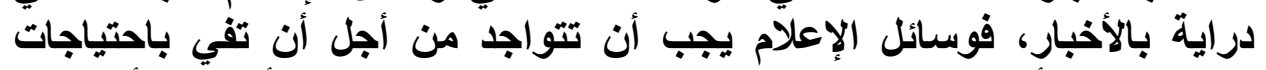

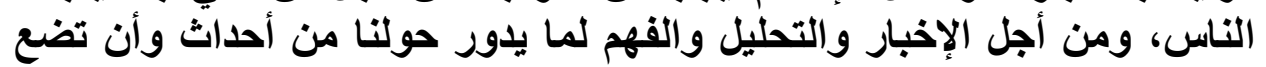

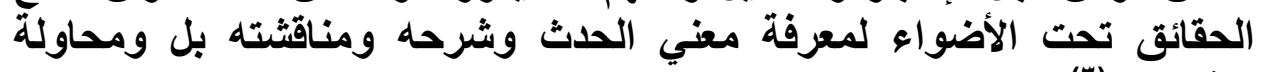

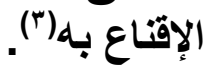
وأُصبحت الأخبار أحد المكونات الأساسية للقتوات الفضائية، خاصةً بعد تزايد

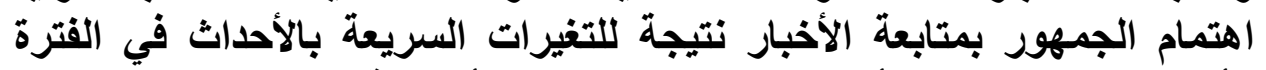

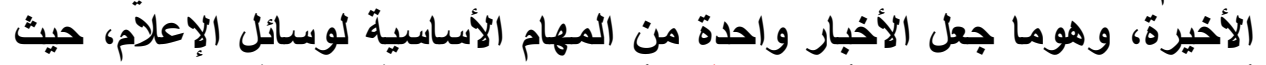
أصبح العالم الذي نعيثه أكثر تعقيدًا وأصبح هنار الكّام حاجة لمعرفة ما يدور حولنا

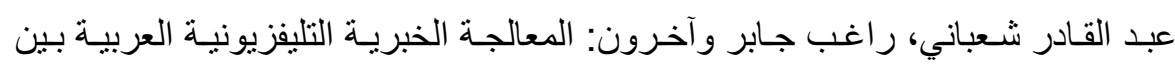

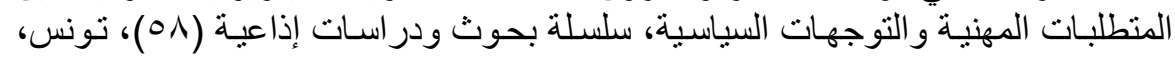

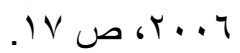
عبد اللطيف شريف، عبد الغني حاج مبارك، اتجاهات الجمهور إزاء مصدافية النهاء الأخبار

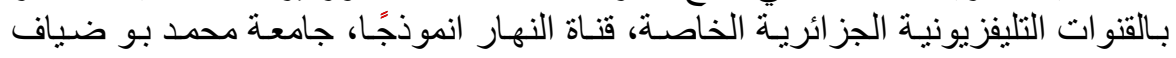

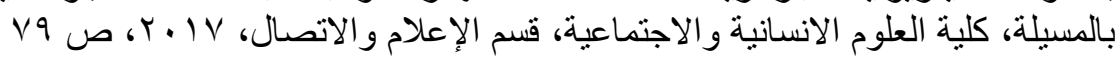

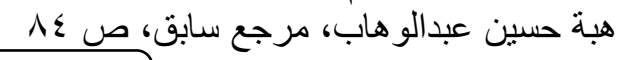
rV $\varepsilon$ 
من أحداث، وباتت القتوات الفضائية تمثل مصدرًا رئيسيًا في الحصول علي

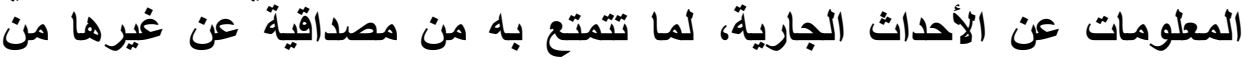
الوسائل، وهذه المصداقية تنبع من طبيعة الوسيلة وخصائصها، حيث الإنة الصوت و

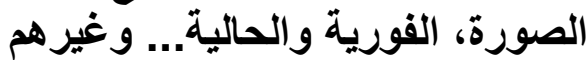

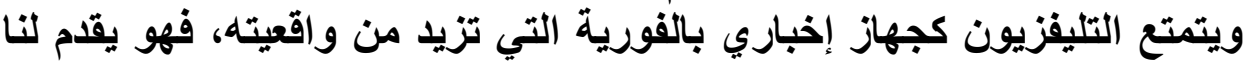

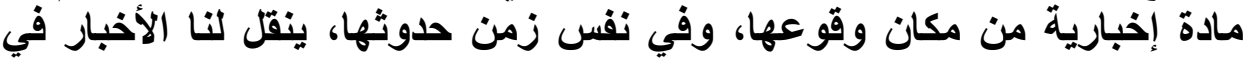

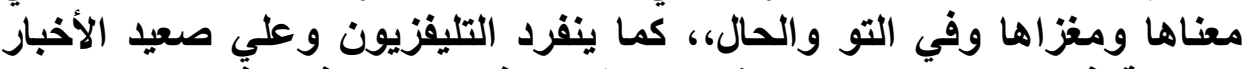

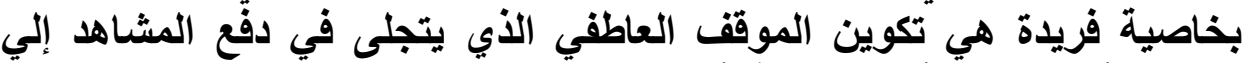

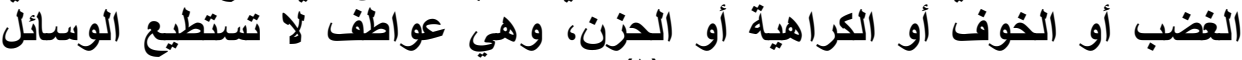

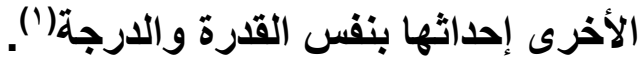

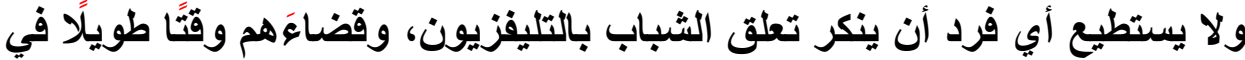

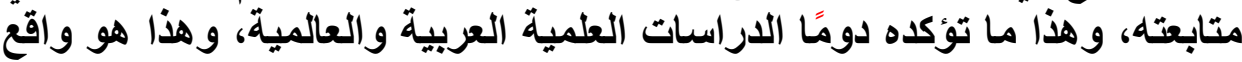

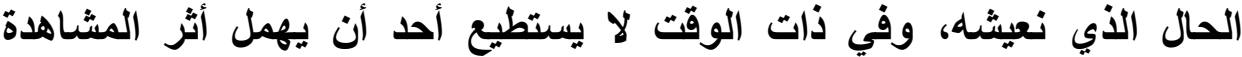

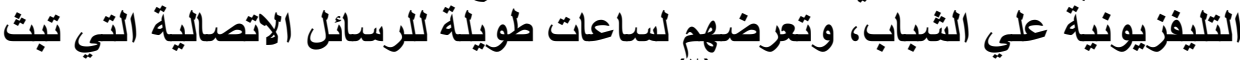

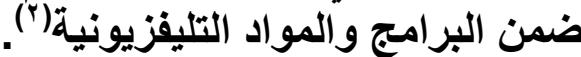

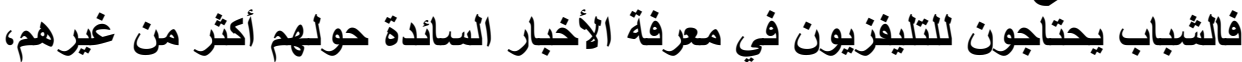

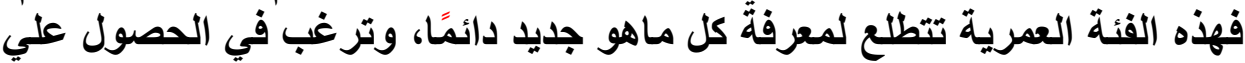

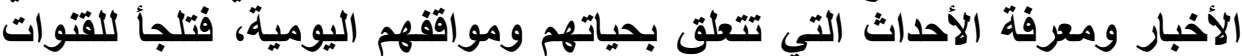

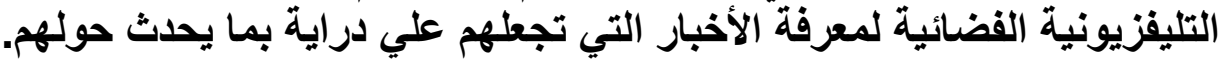

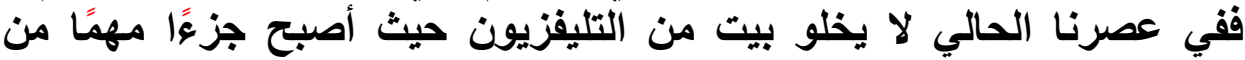

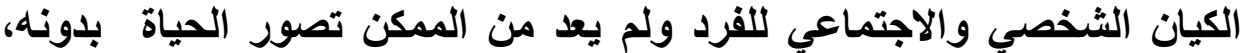

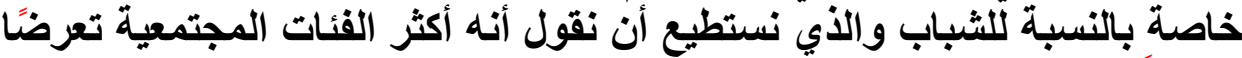

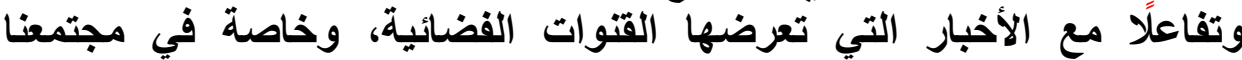

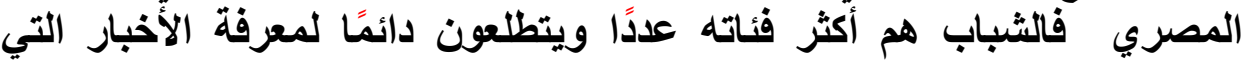

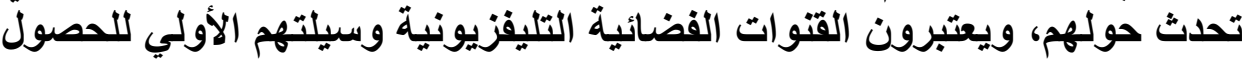
علي الأخبار التي يحتاجونها.

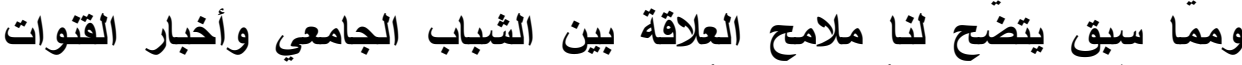

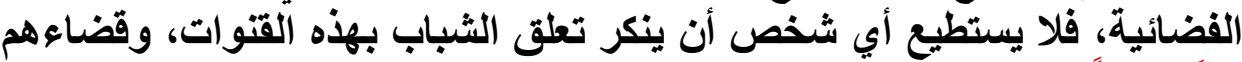

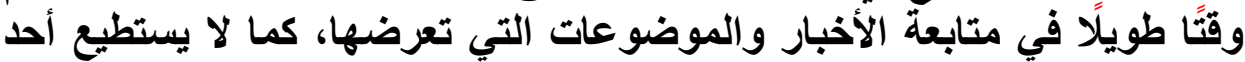

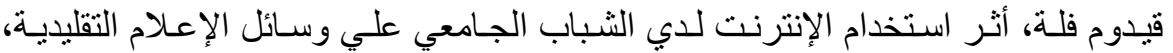

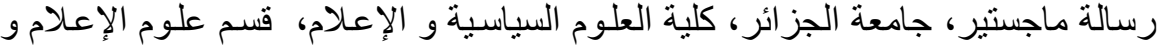

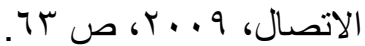

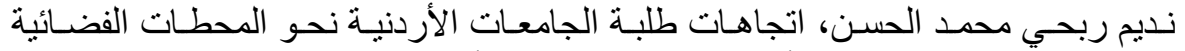

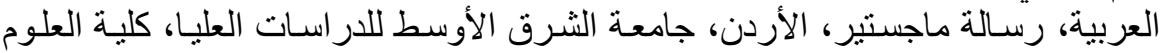

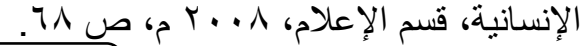




\section{اتجاهات الشباب الجامعي نحو مؤشرات مصداقية الأخبار بالقنوات الفضائية: دراسة ميدانية}

أن يهمل أثر مشاهدة هذه القنوات الفضائية علي الشباب، ودورها في تكوين آرائه، ويناء شخصيته وتثكيل اتجاهاته وسلوكياته.

\section{نتنائم الدراسة المبيدانية ولهية}

\section{أولًا: فصائص وسسمات عينة الدراسة}

جدول رقم (Y) توزيع مفردات عينة الدراسة تبعًا للسمات الايموجرافية الدية

\begin{tabular}{|c|c|c|c|}
\hline النسبة المئوية & التكرار - الت & & السمة الايموجرافية \\
\hline$r r, r$ & 10. & ד أكتوبر & \multirow{4}{*}{ الجامعة } \\
\hline$r r, r$ & 10. & جامعة أسيوط & \\
\hline r r r & 10. & أزهر أسيوط & \\
\hline $1 \cdots \cdot$ & $\leqslant 0$. & المجموع & \\
\hline $0 \cdot . \cdot$ & rYO & كلية نظرية & \multirow{3}{*}{ التخصص } \\
\hline $0 \cdot . \cdot$ & TYO & كلية عملية & \\
\hline $1 \cdots$ & $\leqslant 0$. & المجموع & \\
\hline$\varepsilon v, 1$ & YIr & ذكر & \multirow{3}{*}{ النوع } \\
\hline or, $q$ & rrA & أنثي & \\
\hline $1 \ldots$ & $\leqslant 0$. & المجموع & \\
\hline$\varepsilon, 9$ & YY & أقلّ من 1/ سنة & \multirow{4}{*}{ السن } \\
\hline$v \theta, 1$ & rrs & من ^ I إلي YY سنة & \\
\hline$r \cdot, \cdot$ & 9. & أكثر من Yَr سنة & \\
\hline $1 \cdots \cdot$ & $\leqslant 0$. & المجموع & \\
\hline $7 \leq .9$ & YqY & حضر & \multirow{3}{*}{ محل الإقامة } \\
\hline ro.1 & 101 & ريف & \\
\hline $1 \cdots \cdot$ & $\leq 0$. & المجموع & \\
\hline
\end{tabular}

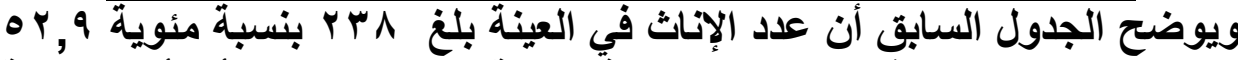

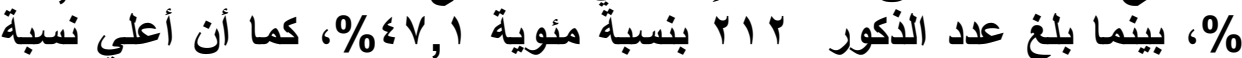

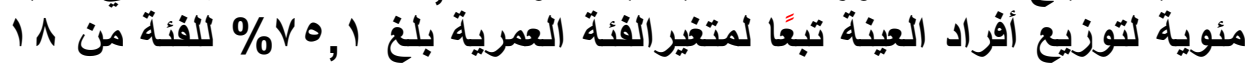

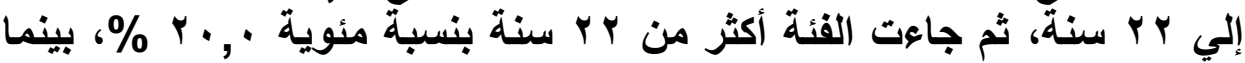

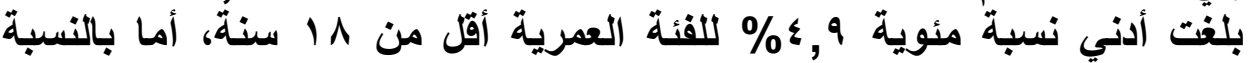

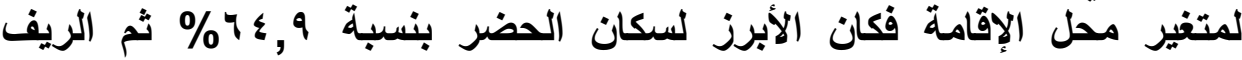
.\% $\%, 1$ 


\section{ثانيًا : النـنائج العامة للدراسة المبدانـية}

(1) مدي متابعة المبحوثين للقتوات الفضائية الحكومية والخاصة، ومعدل

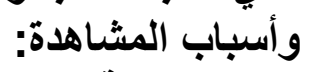

أظهرت نتائج الدراسة مدي متابعة الشباب الجامعي عينة الدراسة،ويتضح ذلتك من خلال الجدول التالي: جدول رقم (T) مدي متابعة المبحوثين للقنوات الفضائية

\begin{tabular}{|c|c|c|}
\hline النسبة المئوية & التكرار & الإجابة \\
\hline OY.V & YrV & نعم \\
\hline$r V_{.0}$ & 179 & أحياتا \\
\hline 9.1 & $\varepsilon \varepsilon$ & نادراً \\
\hline $1 \cdots$ & $\leqslant 0$. & المجموع \\
\hline
\end{tabular}

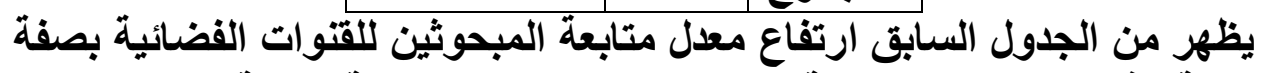

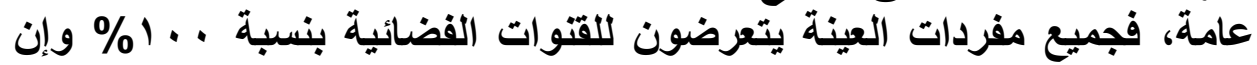

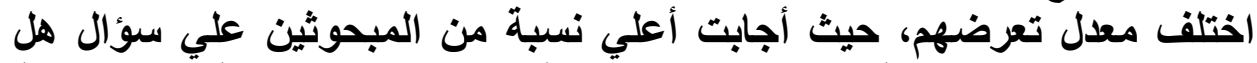

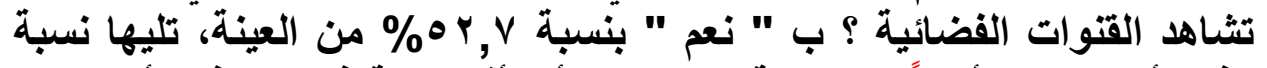

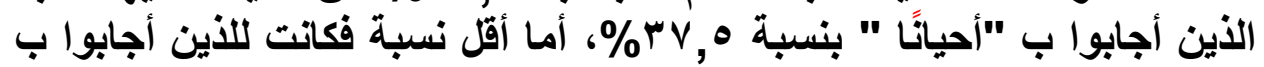

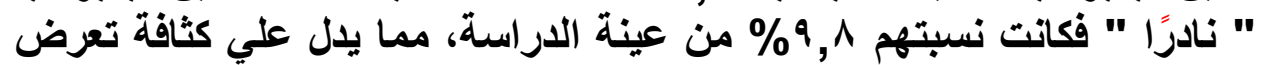

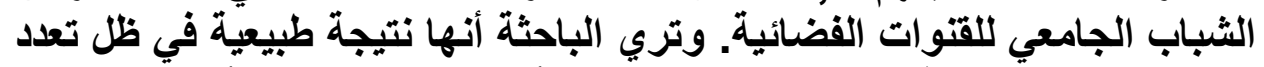

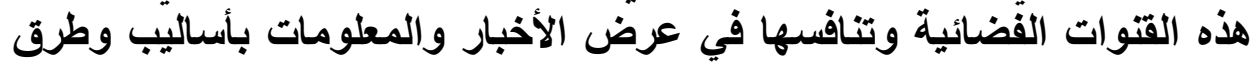

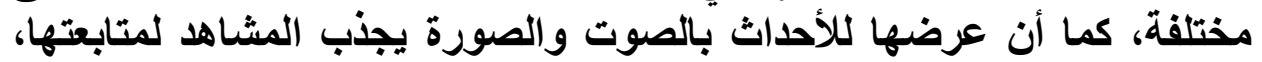

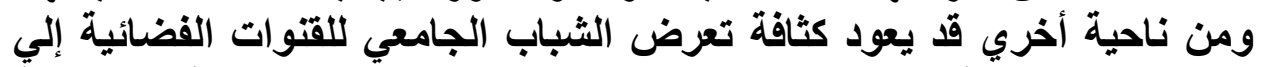

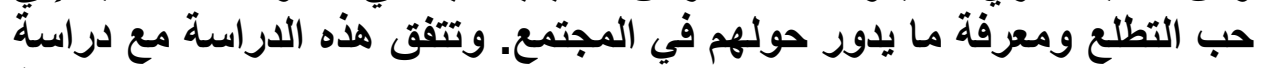

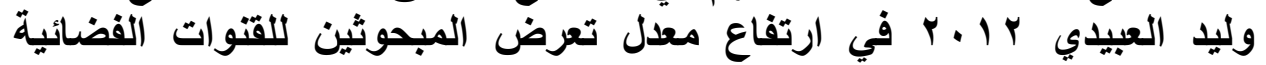

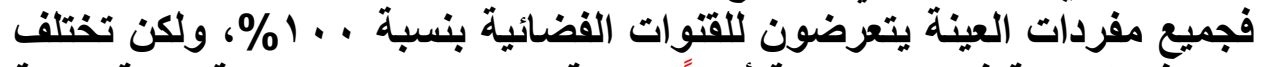

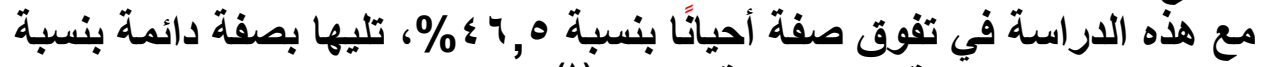

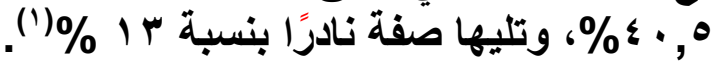

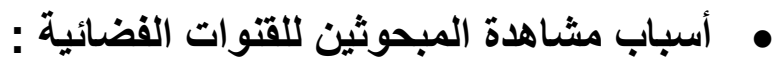
أظهرث النتائج أسباب مشاهدة المبحوثين للقنوات الفين الفضائية، ويتضح ذلك من

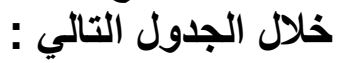




\begin{tabular}{|c|c|c|}
\hline \multicolumn{3}{|c|}{ جدول رقم (ع) أسباب مشاهدة المبحوثين للقتوات الفضائية } \\
\hline النسبة المئوية & 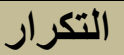 & الإجابة \\
\hline $7 \wedge, r$ & $r \cdot v$ & للحصول علي أحدث الأخبار \\
\hline 1,9 & $\varepsilon$. & لأني أثق في الأخبار التي تعرضها \\
\hline $1 v, r$ & $\vee \wedge$ & لأنها تعرض الأخبار بالصوت والصورة \\
\hline $1 r, r$ & 7. & للاقة والوضوح في نقل الأخبار \\
\hline$M q, r$ & 174 & للتسلية وقضاء وقت الفراغ \\
\hline 1,7 & V & أخري تذكر \\
\hline
\end{tabular}

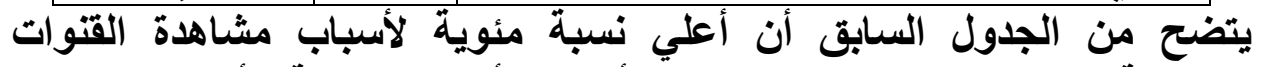

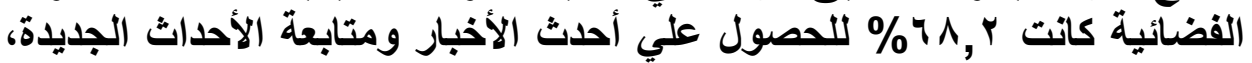

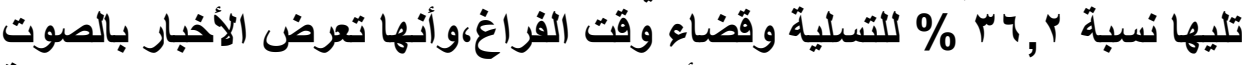

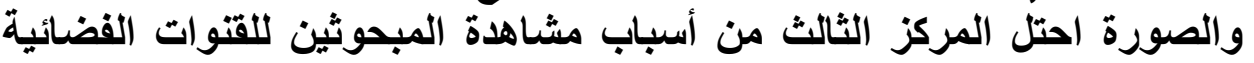

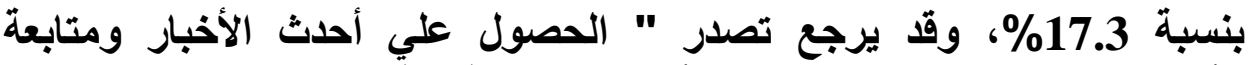

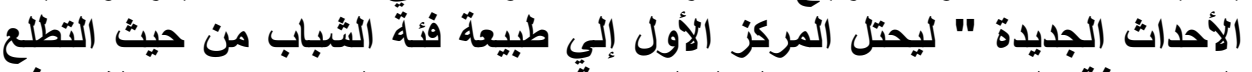

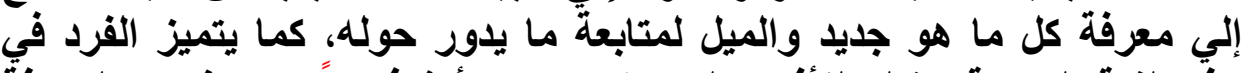

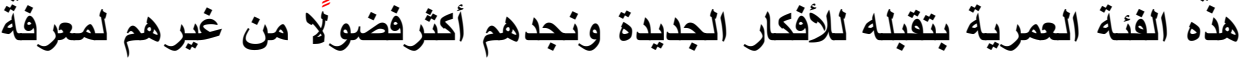

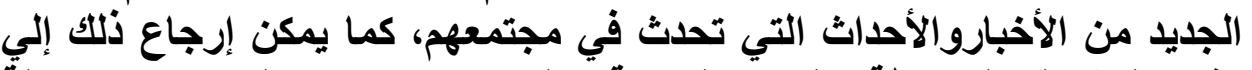

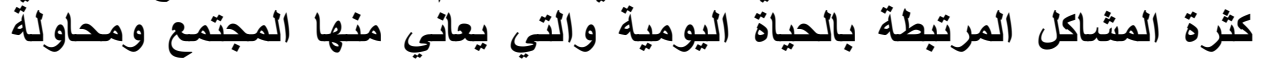

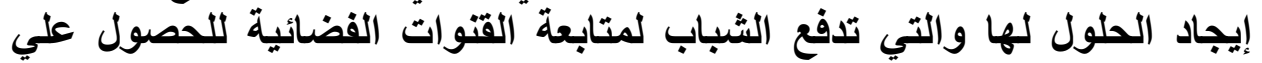

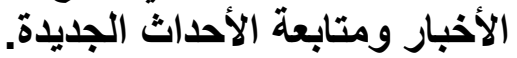

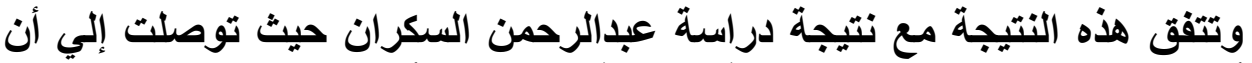

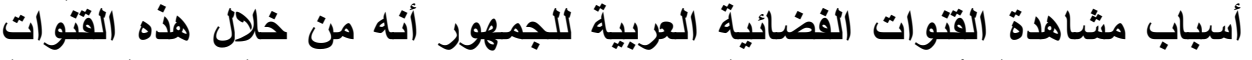

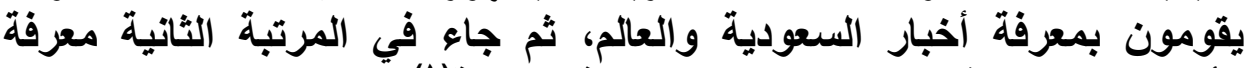

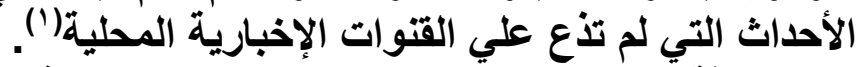

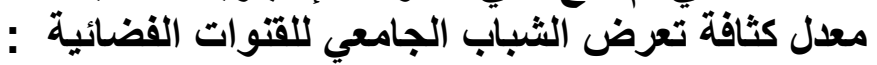

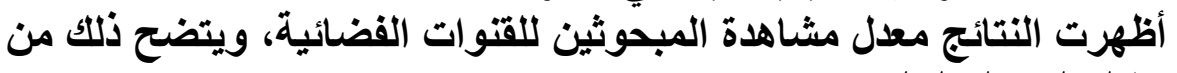

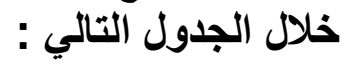

$$
\text { عبدالرحمن أحمد الناصر السكران، مرجع سابق، ص ع ז }
$$


مجلة كلية الآداب، جامعة سوهاج، العدد الثالث والخمسون، الجزء الثاني، أكتوبر 19 • ب م

جدول رقم (0) معدل مشاهدة المبحوثين لأخبار القتوات الفضائية

\begin{tabular}{|c|c|c|}
\hline النسبة المئوية & التكرار & الإجابة \\
\hline$r r, V$ & IV $\varepsilon$ & أقلّ من ساعة \\
\hline$\varepsilon \theta, \Lambda$ & $r . T$ & من ساعة إلي ساعتين \\
\hline 17,2 & $V \varepsilon$ & من ثلاث ساعات إلي أربع ساعات \\
\hline 0,1 & rr & خمس ساعات فأكثز \\
\hline $1 \ldots$ & $\leqslant 0$. & المجموع \\
\hline
\end{tabular}

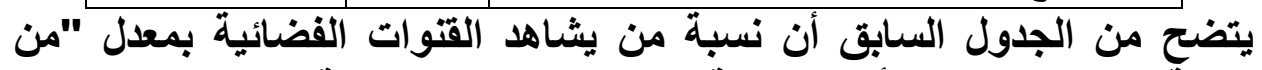

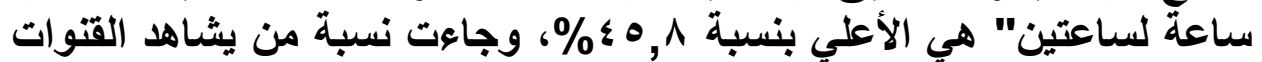

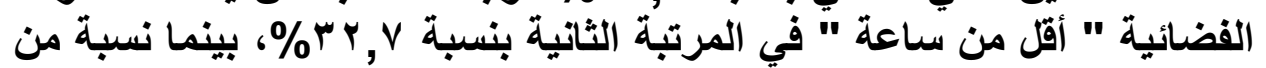

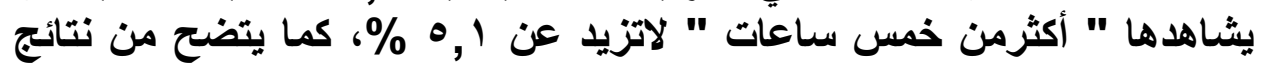

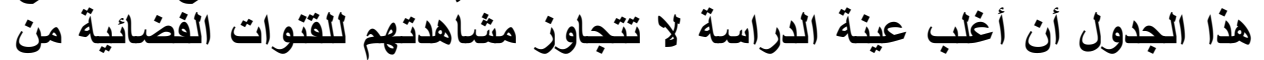

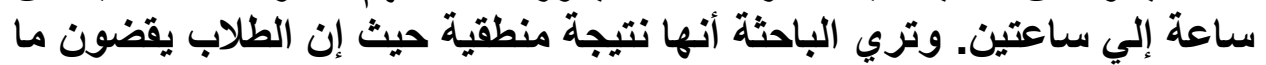

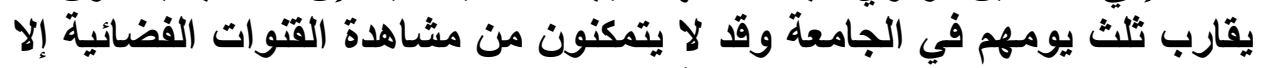

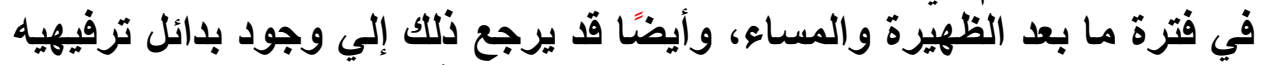

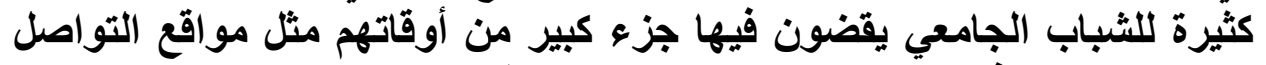

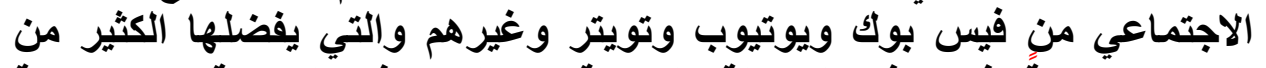

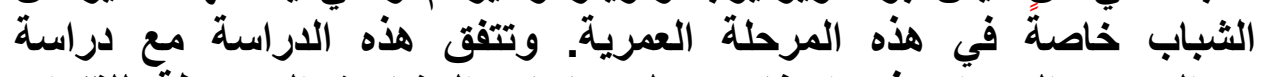

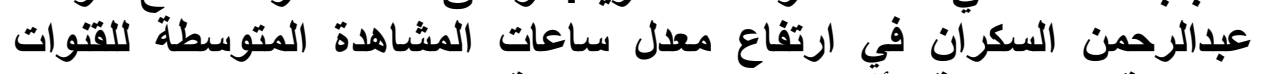

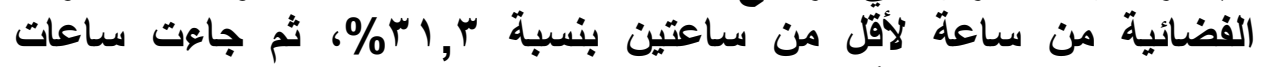

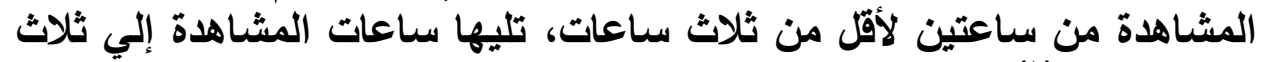

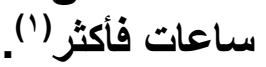
مدي اهتمام عينة الاراستة بمتابعة أخبار القتوات الفضاتئة الفيائة:

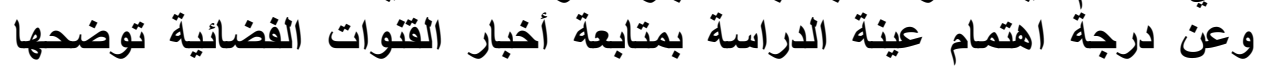

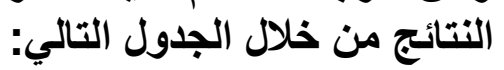
جدول رقم (7) مدي الهتمأم عينة الاراسة بمتابعة أخبار القتوات الفضائية

\begin{tabular}{|c|c|c|}
\hline النسبة المئوية & التكرار & الإجابة \\
\hline $1 \leq . r$ & $7 \varepsilon$ & اهتم بلرجة كبيرة \\
\hline$\varepsilon V . r$ & $r \mid r$ & اهتم بلرجة متوسطة \\
\hline$Y \leq . \varepsilon$ & 11. & اهتم بدرجة ضعيفة \\
\hline $1 \leq .1$ & 4 & لا اهتم علي الإطلاق \\
\hline $1 \ldots$. & $\varepsilon 0$. & المجموع \\
\hline
\end{tabular}


يتضح من الجدول السابق أن أغلب عينة الدراسة تهتم بمتابعة أخبار القتوات

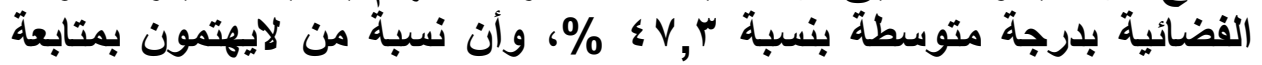

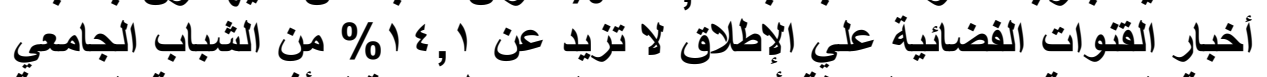

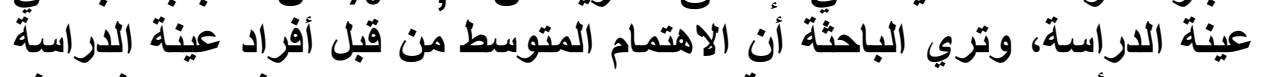

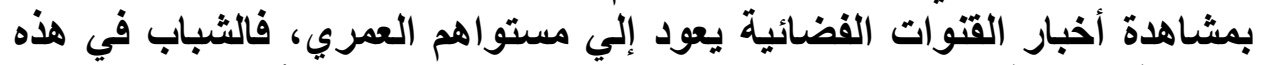

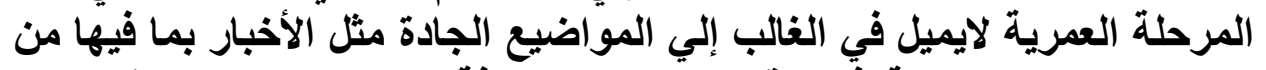

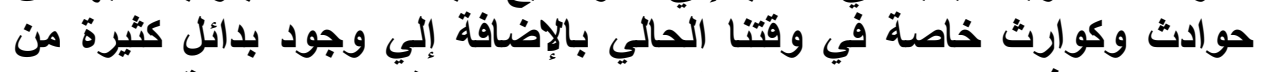

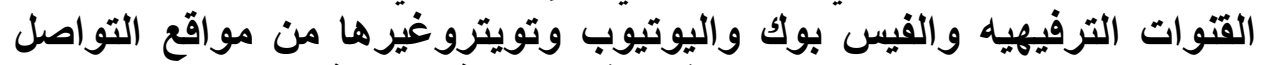

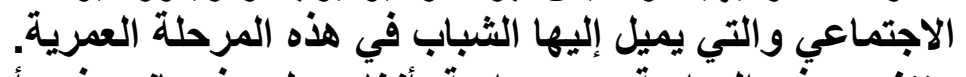

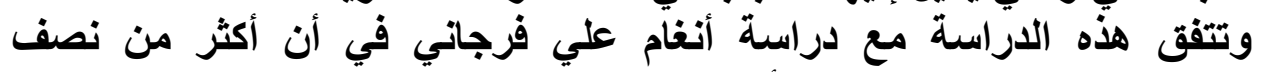

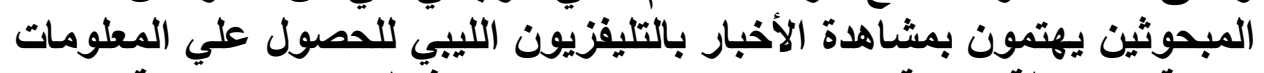

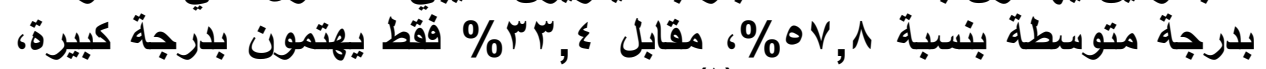

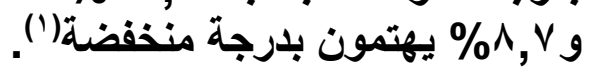

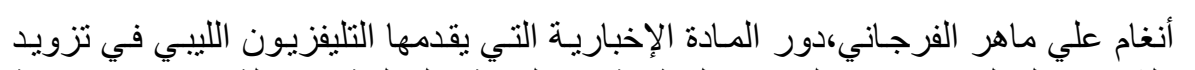

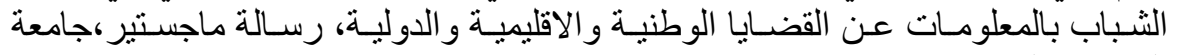

rᄉ. 


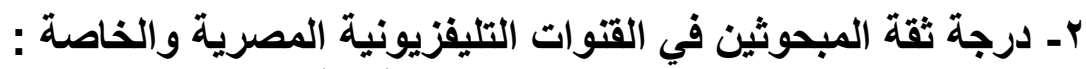

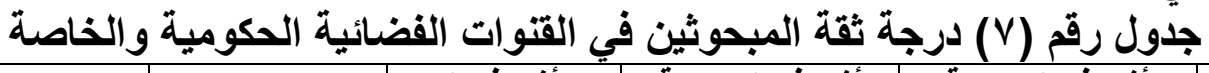

\begin{tabular}{|c|c|c|c|c|c|c|c|c|c|c|c|c|}
\hline \multirow{2}{*}{ التقدجة } & \multirow{2}{*}{ الانحرافي } & \multirow{2}{*}{ الحستوسطي } & \multicolumn{2}{|c|}{ لا أثق فيها } & \multicolumn{2}{|c|}{ بدرجة ضئية فيهة } & \multicolumn{2}{|c|}{ أثق فيها بدرجة } & \multicolumn{2}{|c|}{ أثق فيبها بلرجة } & \multirow{2}{*}{ القناة الفضائية } & \multirow[t]{2}{*}{ r } \\
\hline & & & نسية & ت تكرار & نسية & ت تكرار & نسبة نوية & ت تكرار & مئوية نسبة & ت تكرار & & \\
\hline منخفضة & $1, \cdot \leq 9$ & $1,0$. & YI. & 91 & YV.I & IYY & $\mu \cdot . \varepsilon$ & IrV & $Y \cdot . V$ & 94 & الأولي & 1 \\
\hline منخفضة & $\cdot, 99 \leq$ & $1, M_{1}$ & $Y \varepsilon . \varepsilon$ & 11. & $r \varepsilon . r$ & 100 & 57.9 & $|Y|$ & $1 \varepsilon . Y$ & $7 \varepsilon$ & النيل & $r$ \\
\hline منخفضة & $1, \cdots 7$ & $1, r$. & $r \varepsilon . V$ & 111 & rq. r & 174 & Yr. & $1 \cdot v$ & $10 . r$ & 79 & المضريةية الفضية & $r$ \\
\hline منخفضة & 1,49 & $1, Y Y$ & $r \cdot$. & 170 & TY.V & $1 \leqslant V$ & YY.Y & $1 \ldots$ & 10.1 & 71 & الثاتية & $\varepsilon$ \\
\hline متوسطة & $\cdot, 91 V$ & $r, r$ & $1 .$. & $\leqslant 0$ & $1 \cdot . v$ & $\varepsilon \wedge$ & $\varepsilon 7$. & $1 \cdot V$ & r.r & 10. & CBC & 0 \\
\hline متوسطة & $\cdot, 904$ & $r, \cdot q$ & 9.1 & $\& 1$ & $1 \varepsilon$. & rq & rq.. & $17 \%$ & $8 \cdot .9$ & $1 \wedge \varepsilon$ & الحياة & 7 \\
\hline متوسطة & $\cdot, 9 \leq 7$ & $r, 0$ & $1 . . V$ & $\varepsilon \wedge$ & $1 \cdot . \varepsilon$ & $\leqslant V$ & $\varepsilon Y . \varepsilon$ & 191 & M. & $17 \varepsilon$ & النهار & $\mathrm{V}$ \\
\hline متوسطة &., 97. & $r, \ldots$ & $1 \cdot .2$ & $\varepsilon V$ & $1 \varepsilon .9$ & $7 V$ & $r q . r$ & IVV & ro.r & 109 & القاهرة والناس & $\Lambda$ \\
\hline منخفضة & $\because A V \mu$ & $1, \mu$ & & & & كمية & م & قة ف & لعام لار & المتوب & & \\
\hline متوسطة & $\because V \vee r$ & $Y, \cdot \varepsilon$ & & & & اصة & تاتوات & ثقة فو & العام لار & المتو & & \\
\hline
\end{tabular}

يوضح الجدول السابق مدي ثقة المبحوثين في القنوات التليفزيونية الحكومية والخاصة، ونلاحظ أن القتوات القات الفضائية الخاصة

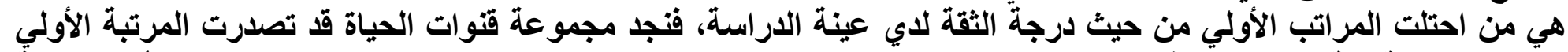

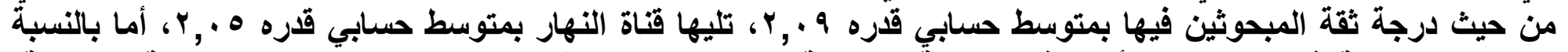

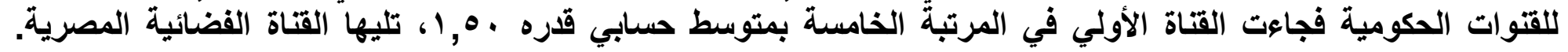




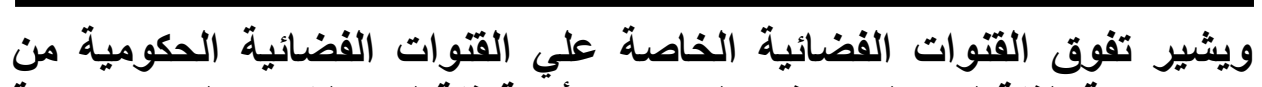

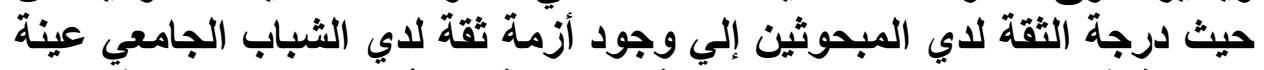

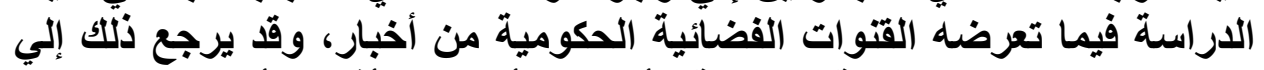

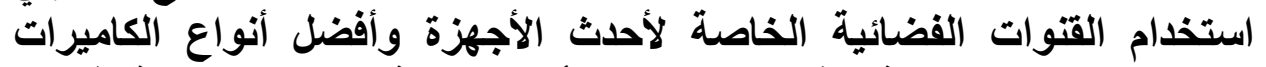

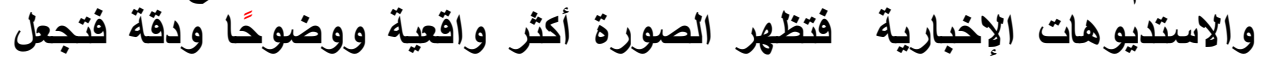

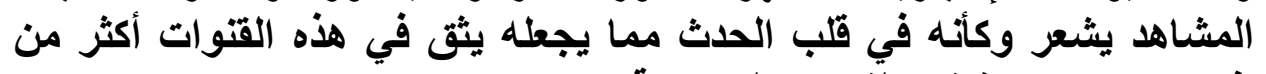

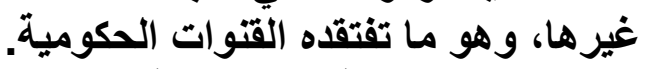

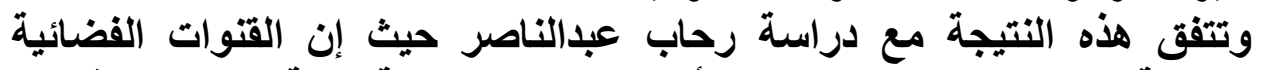

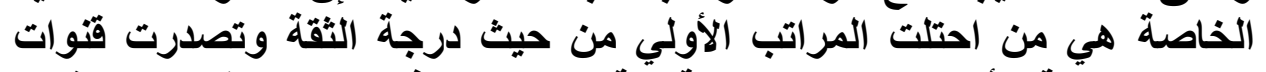

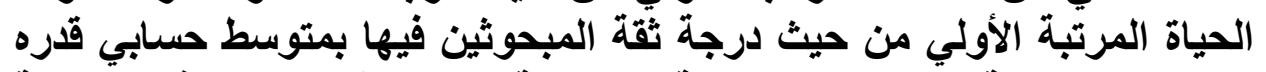

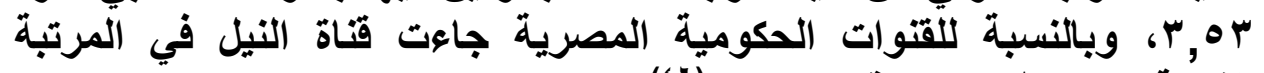

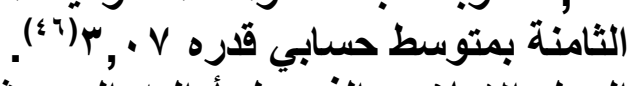

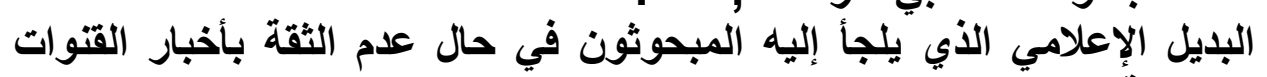
الفضائية : الإعلائ جلول رقم (^) البديل الإعلامي الأي يلجأ إليه المبحوثين عند عدم الثقة في القنوات الفضي الفيائية

\begin{tabular}{|c|c|c|}
\hline النسبة المئوية & التكرار & الإجابة \\
\hline 10,7 & $V \cdot$ & الصحف \\
\hline$r, V$ & ir & المجلات \\
\hline 11,7 & Or & المحطات الإذاعية \\
\hline 7,8 & rq & الصحف الإلكترونية \\
\hline$r \wedge, V$ & $1 r q$ & مواقع التواصل الاجتماعي \\
\hline$r Y, Y$ & $1 \cdots$ & المواقع الإكترونية الإخبارية \\
\hline$v, r$ & $r r$ & وكالات الأنباء \\
\hline 0,7 & ro & لا يوجد \\
\hline $1 \cdots$ & $\leqslant 0$. & المجموع \\
\hline
\end{tabular}

يتضح من الجدول السابق أن مواقع التواصل الاجتماعي احتلت المرتبة الأولي

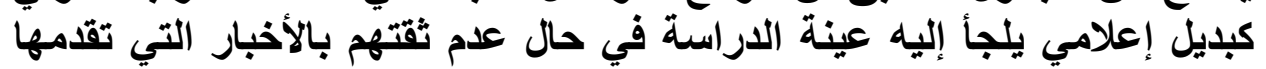

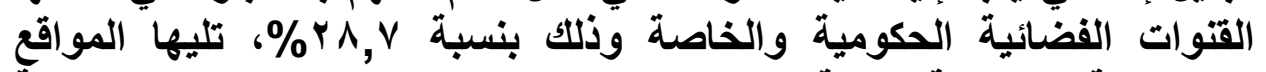

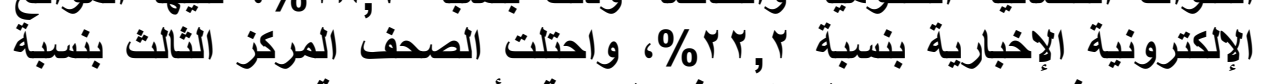

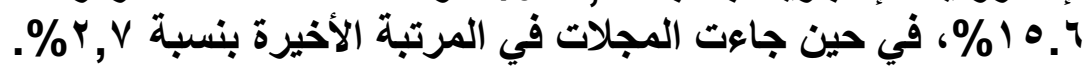


مجلة كلية الآداب، جامعة سوهاج، العدد الثالث والخمسون، الجزء الثاني، أكتوبر 19 • ب م

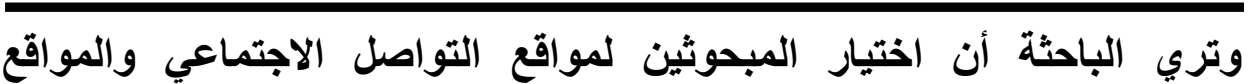

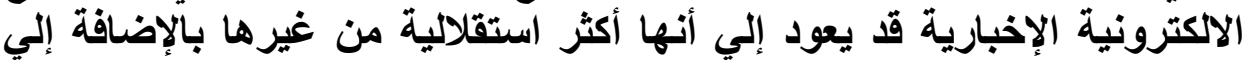

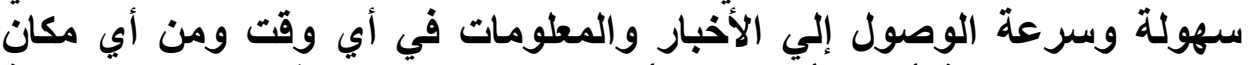

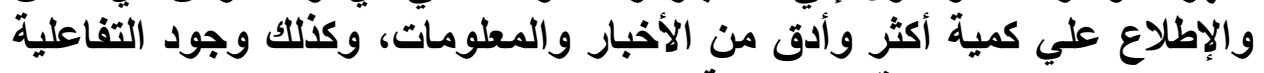

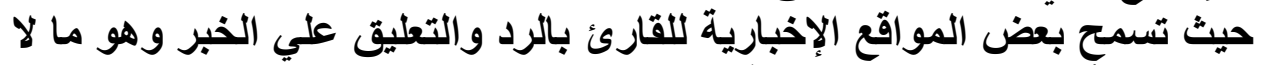
يتوفر في أخبار القتوات الفضائية.

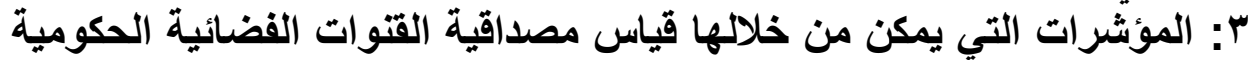

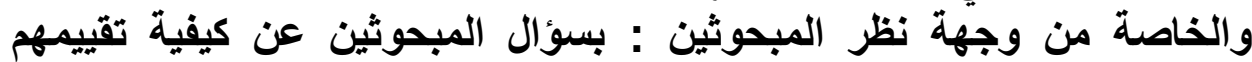

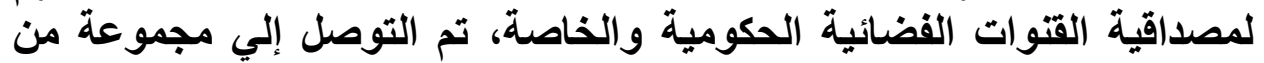
أبعاد ومؤشر المة للمصدات الفية. 


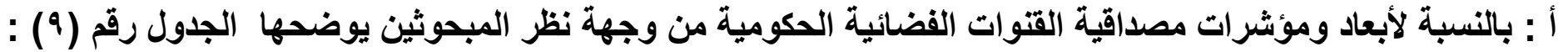

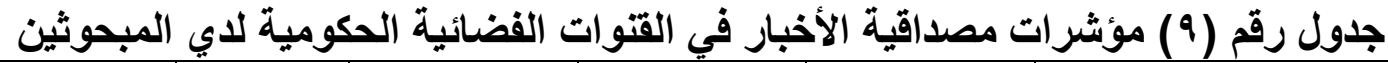

\begin{tabular}{|c|c|c|c|c|c|c|c|c|c|c|c|}
\hline \multirow[b]{2}{*}{ 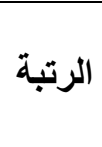 } & \multirow[b]{2}{*}{ التقدجير } & \multirow[b]{2}{*}{ الانحراف } & \multirow{2}{*}{ الحستوسطي } & \multicolumn{2}{|c|}{ معارض } & \multicolumn{2}{|c|}{ محايد } & \multicolumn{2}{|c|}{ موافق } & \multirow[b]{2}{*}{ عناصرومؤشرات المصداقية } & \multirow[b]{2}{*}{ r } \\
\hline & & & & نسبة مئة & تكرار & مئوية نسبة & تكرار & نسبة & تكرار & & \\
\hline$r$ & متوسطة & $\cdot, \wedge \leq 7$ & r.11 & $r \cdot, q$ & 119 & $r v, r$ & Irr & $\varepsilon 1, \wedge$ & $1 \wedge 1$ & الفورية والحالية في تغطية الأحداث & 1 \\
\hline 9 & متوسطة & $\because \wedge \bullet 0$ & $1 . \wedge$ & $\varepsilon \wedge, \vee$ & P1q & $r r, q$ & $1 \cdot r$ & $r \wedge, \varepsilon$ & $I r A$ & الاقة في نقل الأحداث & $r$ \\
\hline 14 & متوسطة & 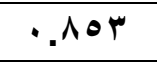 & $1 . v$. & $00, \Lambda$ & Y01 & $11, \varepsilon$ & $\Lambda \mu$ & $r \bullet, \Lambda$ & 117 & فصل الرأي عن المعلومات والحقائق & $r$ \\
\hline 7 & متوسطة & $\cdot, \Lambda Y r$ & 1.10 & $\varepsilon r, \varepsilon$ & 191 & $r \cdot, r$ & $1+4$ & $r v, r$ & Irr & تقديم أدلة وبر اهين & $\varepsilon$ \\
\hline$r$ & متوسطة & $\bullet, \wedge 9$. & $r, \cdots$ & $r q, \wedge$ & 189 & $r \cdot, q$ & $9 \varepsilon$ & $r q, r$ & IVV & عرض الأحداث بلغة سهلةوبسيطة & 0 \\
\hline 1. & متوسطة & $\cdot, \wedge \circ \varepsilon$ & $1, V \varepsilon$ & or, & $r r q$ & $r \cdot, r$ & 91 & $r q, V$ & $1 \%$. & توثيق المعلومات ونسبها إلي مصادرها & 9 \\
\hline$\varepsilon$ & متوسطة & $\cdot, \wedge \leq 1$ & 1,90 & $\mu \wedge$, & $|V|$ & $r q, 1$ & $|r|$ & $r r, q$ & $1 \leqslant 1$ & الوضوح في اللغة والأفكار & $v$ \\
\hline 1 & متوسطة & $\bullet, \wedge \uparrow$ & r.Mr & $r q$, & $11 \mathrm{~V}$ & 10,1 & VI & $\Delta \wedge, r$ & rqr & عدم التهوين أوالتهويل في القضايا & $\Lambda$ \\
\hline$r$ & متوسطة & $\cdot, \wedge \leq 0$ & 1.81 & $0 \leqslant, \varepsilon$ & $r \leq 0$ & $r \cdot, r$ & 91 & $r \bullet, r$ & $11 \varepsilon$ & عرض الحدث بمختلف جوانبه & 9 \\
\hline 9 & منخفضة & $\cdot, \wedge \mu r$ & $1.7 \mathrm{~V}$ & $07, r$ & ror & $r \cdot, r$ & 91 & $r r, q$ & 1.7 & التفاعلية في القناة وطرح آراء & 1. \\
\hline $1 T$ & متوسطة & $\cdot, \wedge \leq \curlyvee$ & $1 . V Y$ & $0 \leqslant$, & $r \leq r$ & $r \cdot, \varepsilon$ & $q r$ & Yo,, & 110 & التعبيرعن هموم واحتياجات الجمهور & 11 \\
\hline 7 & متوسطة & $\cdot, \wedge \uparrow 0$ & $1 . \wedge V$ & $\varepsilon \varepsilon, 9$ & $r \cdot r$ & $r r, y$ & 1.7 & r I & $1 \leqslant r$ & الالتزام بالمعايير الأخلاقية & Ir \\
\hline$r$ & متوسطة & $\cdot, \wedge 11$ & 1.71 & $\Delta r, \Lambda$ & $r \leqslant r$ & $r \leq, r$ & 1.9 & $r r, \cdot$ & 99 & التزام المذيعين بالمعايير الأخلاقية & 14 \\
\hline 1. & متوسطة & $\cdot, \wedge \cdot \Lambda$ & 1.89 & $\varepsilon 0, r$ & $r \cdot \varepsilon$ & $r \cdot, \varepsilon$ & IrV & $r \varepsilon, Y$ & 1.9 & الاعتماد علي مصادر موثوق فيها & $1 \leq$ \\
\hline$\varepsilon$ & متوسطة & $\cdot, \wedge M_{1}$ & 1.11 & $\varepsilon 7$, & $r \cdot V$ & $r V, r$ & Irr & $r q, V$ & $1 \%$ & الاعتماد علي مصادر متخصصة & 10 \\
\hline & متوسطة & .009 & 1.10 & & & & & & ط العام & الم & \\
\hline
\end{tabular}


يتضح من الجدول السابق أن مؤشرات وأبعاد المصداقية التي تميزت بهات

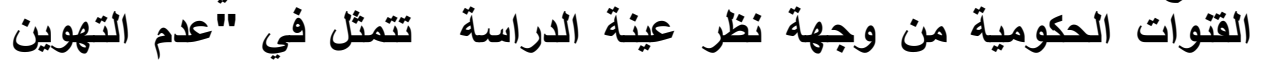

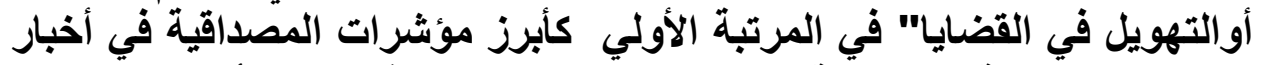

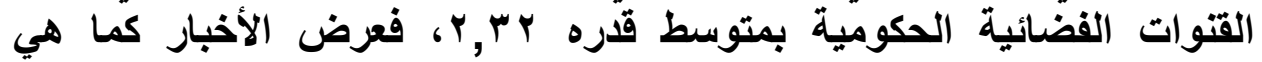

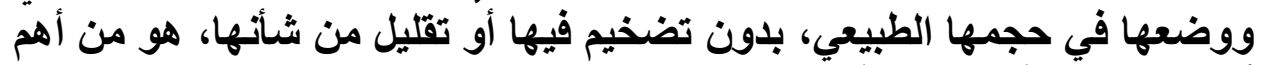
أبعاد المصداقية من وجهة نظر المبحوثين. يأتي في المرتبة الثانية " الفورية والحالية الثراية في تغطية الأحداث " بمتوسط قدره

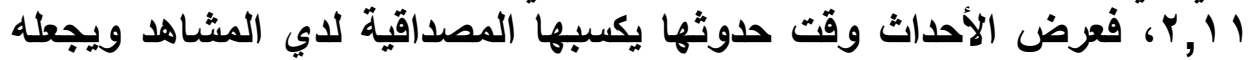

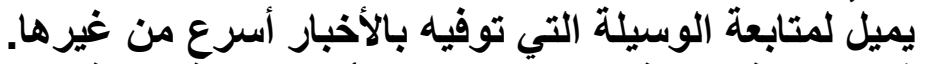

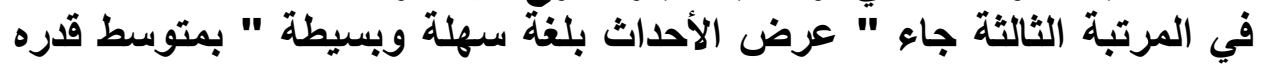

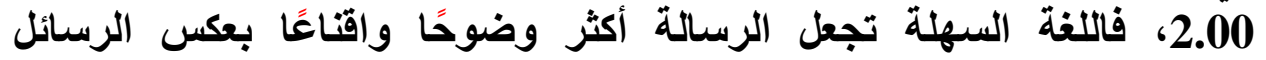

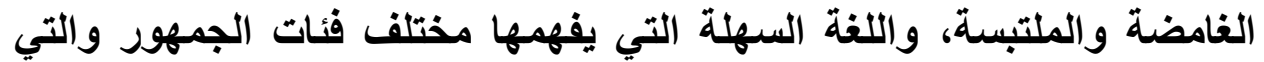

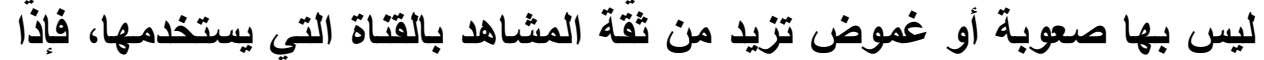

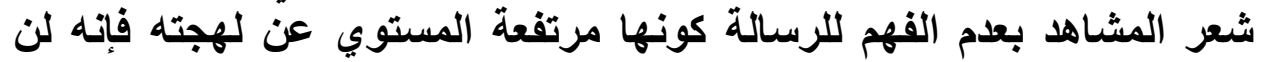

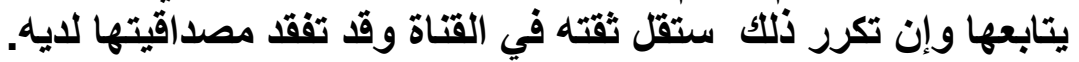

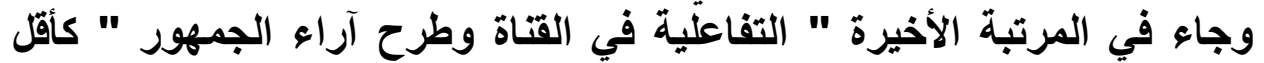

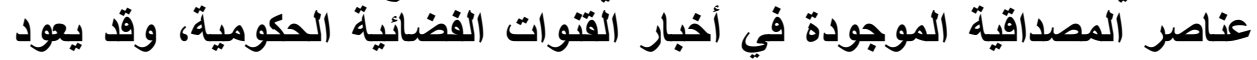

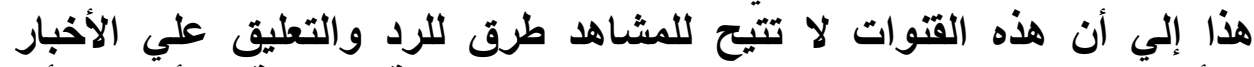

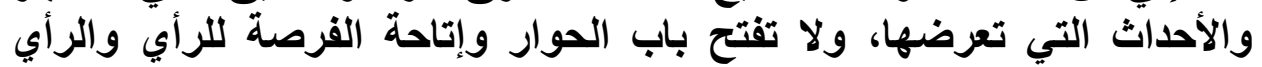

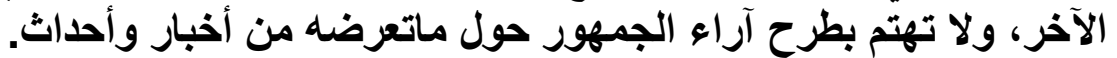

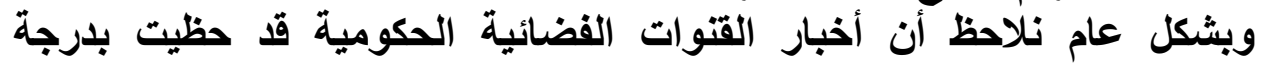

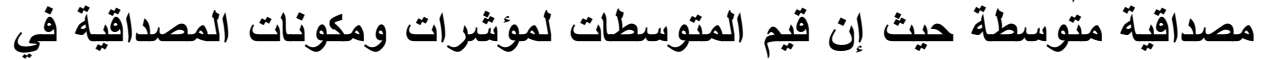

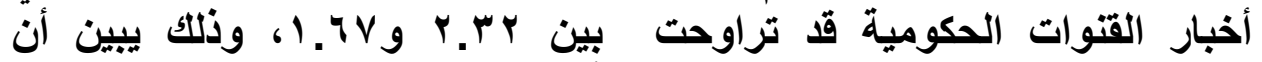

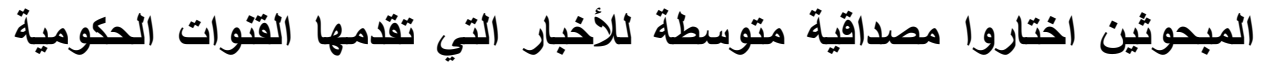

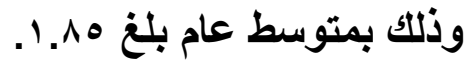

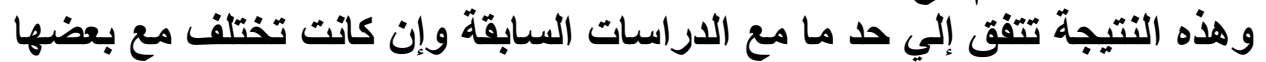

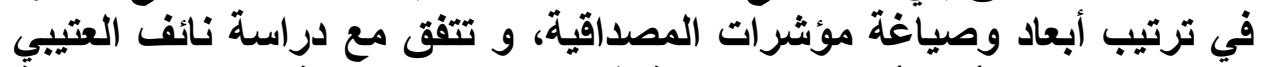

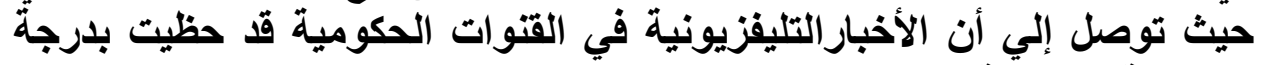
مصداقية متوسطة. ب : بالنسبة لأبعاد ومؤشرات مصداقية القتوات الفضائية الخاصة من وجهة

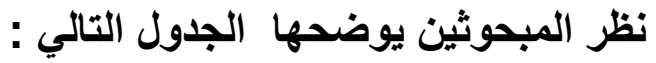


جدول رقم (· 1) مؤشرات مصداقية الأخبار في القتوات الفضائية الخاصة لاي المبحوثين

\begin{tabular}{|c|c|c|c|c|c|c|c|c|c|c|c|}
\hline \multirow[b]{2}{*}{ الرتبة } & \multirow[b]{2}{*}{ التقدجير } & \multirow[b]{2}{*}{ الانحراف } & \multirow[b]{2}{*}{ المستوسطي } & \multicolumn{2}{|c|}{ معارض } & \multicolumn{2}{|c|}{ محايل } & \multicolumn{2}{|c|}{ موافق } & \multirow[b]{2}{*}{ عناصرومؤشرات المصداقية } & \multirow[b]{2}{*}{ r } \\
\hline & & & & مئوية نسبة & 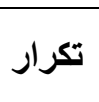 & مئوية نسبة & 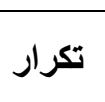 & نسبة نسية & 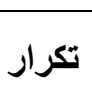 & & \\
\hline 0 & مرتفعة & $\cdot, 817$ & r.Or & $1 \%, 1$ & 09 & Y1، A & $9 \wedge$ & 70,1 & rqu & الفورية والحالية في تغطية الأحداث & 1 \\
\hline 1. & مرتفعة & $\cdot, 7 \wedge \wedge$ & Y.O. & 11,1 & 0 . & $r v, \Lambda$ & iro & 71,1 & rVo & الاقة في نقل الأحداث & r \\
\hline $1 \leq$ & متوسطة & $\cdot, \wedge \leq q$ & r. rV & $r q, r$ & 111 & $r \cdot, q$ & $9 \varepsilon$ & or, q & rra & فصل الرأي عن المعلومات والحقائق & $r$ \\
\hline Ir & مرتفعة & $\cdot, V \otimes 0$ & $r . \varepsilon r$ & $17, r$ & vr & ro, & 110 & $\theta \wedge, Y$ & ryt & تقديم أدلة وبراهين & $\varepsilon$ \\
\hline$r$ & 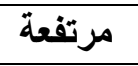 & $\cdot, 7 \vee \wedge$ & r.OV & $1 \cdot, v$ & $\varepsilon \Lambda$ & Y 1,7 & $9 V$ & $9 V, \Lambda$ & $r .0$ & عرض الأحداث بلغة سهلة وبسيطة & $\bullet$ \\
\hline 11 & مرتفعة & $\cdot, \mathrm{V} \bullet \wedge$ & $r . \varepsilon V$ & $17, r$ & Vr & $r \cdot, q$ & $9 \leq$ & $9 r, q$ & rAr & توثيق المعلومات ونسبها إلي مصادرها & 7 \\
\hline 9 & مرتفعة & $\cdot, V \leq \varepsilon$ & Y.01 & 10,1 & 71 & 11,9 & 10 & 97, & Y१V & الوضوح في اللغة و الأفكار & V \\
\hline 10 & متوسطة & $\cdot, \wedge \neg \mu$ & $1 . V Y$ & 00,1 & $r \leqslant \Lambda$ & IV, 1 & $\Lambda$. & $r v, 1$ & IYr & عدم التهوين أوالتهويل في القضايا & $\Lambda$ \\
\hline$\varepsilon$ & مرتفعة & $\cdot, 719$ & r.Or & $1 r, r$ & 7. & $r \cdot, r$ & 91 & 79,8 & rqq & عرض الحدث بمختلف جوانبه & 9 \\
\hline$r$ & مرتفعة & $\cdot, 794$ & Y.०A & 11,1 & $\Delta r$ & $1 \wedge, \varepsilon$ & Ar & 79,1 & ris & التفاعلية في القناة وطرح آراء الجمهور & 1. \\
\hline V & مرتفعة & $\cdot, V \leq \varepsilon$ & Y.01 & 10,1 & VI & $1 \wedge, v$ & $\Lambda \varepsilon$ & 70,0 & rqo & التعبيرعن هموم واحتياجات الجمهور & 11 \\
\hline 9 & مرتفعة & $\cdot, V \otimes r$ & Y.O. & 10,1 & $\sqrt{ } 1$ & $1 \wedge, V$ & $\Lambda \varepsilon$ & 90,0 & rqo & الالتزام بالمعاييز الأخلاقية & Ir \\
\hline $1 T$ & مرتفعة & $\cdot, \mathrm{V} \bullet \wedge$ & $r . r \Lambda$ & 17,9 & 17 & $r \wedge, r$ & IrV & $0 \leqslant, 9$ & $r \leq V$ & التزام المذيعين بالمعايير الأخلاقية & $1 r$ \\
\hline 1 & مرتفعة &. .797 & $Y .71$ & $1 \cdot, r$ & $\leqslant 7$ & 11,9 & 10 & $V \cdot, 9$ & 119 & الاعتماد علي مصادر موثوق فيها & $1 \varepsilon$ \\
\hline$\Lambda$ & مرتفعة & $\cdot, V Y r$ & $r .01$ & 14,7 & 71 & $r 1, \Lambda$ & 91 & $7 \varepsilon, V$ & Yq1 & الاعتماد علي مصادر متخصصة & 10 \\
\hline & مرتفعة & & $Y . \varepsilon \varepsilon$ & & & & & & & & \\
\hline
\end{tabular}


يتضح من الجدول السابق أن مؤشرات وأبعاد المصداقية التي تميزت بها

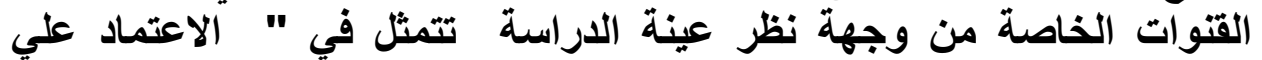
مصادر موثوق فيها " في المرتبة الأولي كأبرز مؤشرات الثرات المئة المصداقية في أخبار

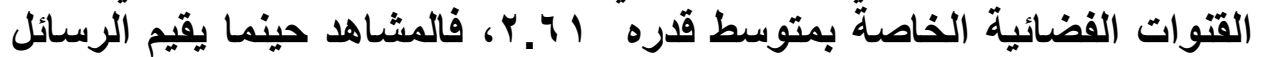

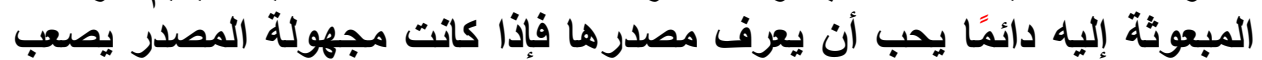

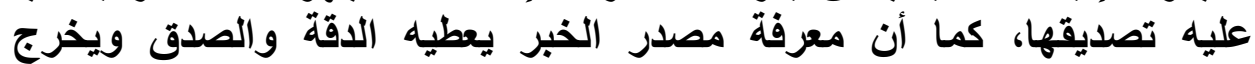

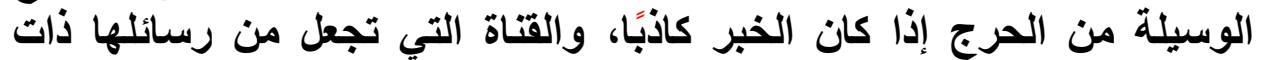

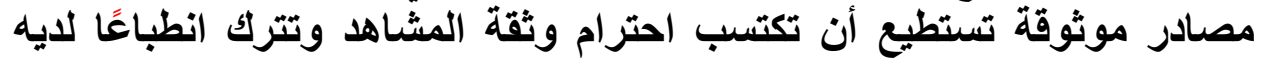

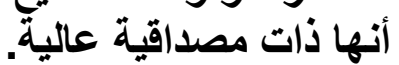

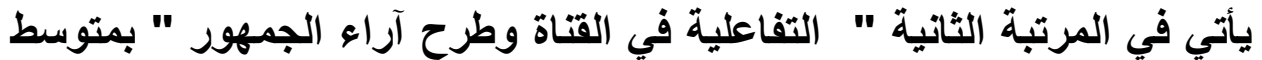

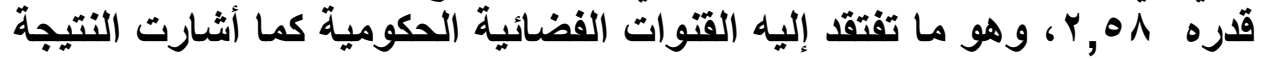

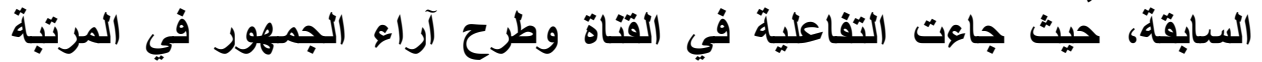

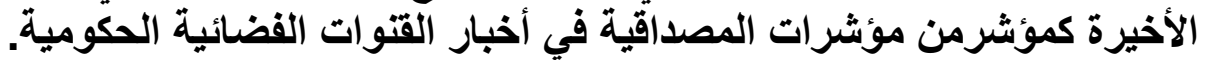

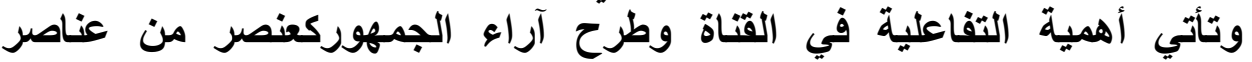

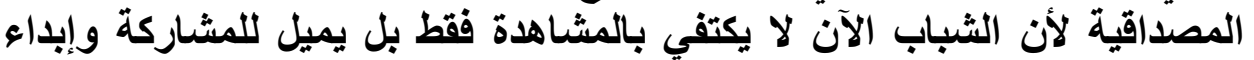

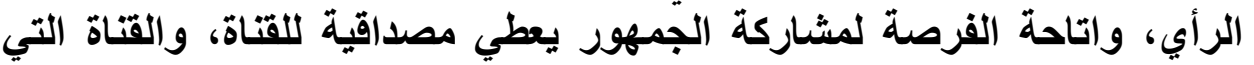

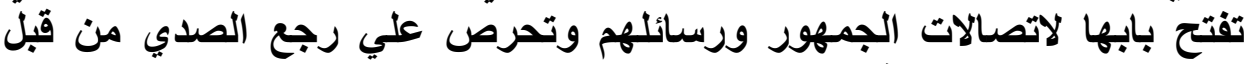

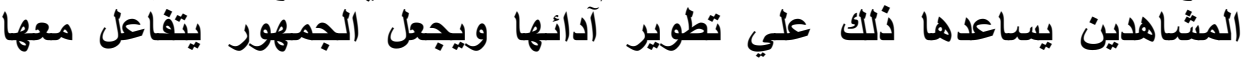

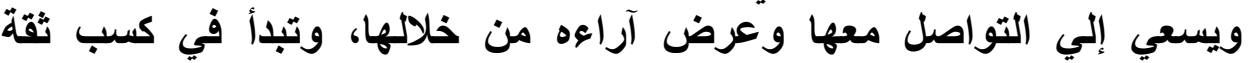

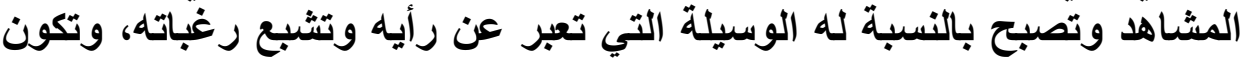

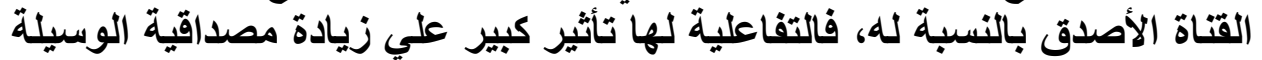

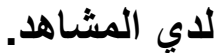
في المرتبة الثالثة جاء "عرضا المثان الأحداث بلغة سهلة وبسيطة " بمتوسط قدره و

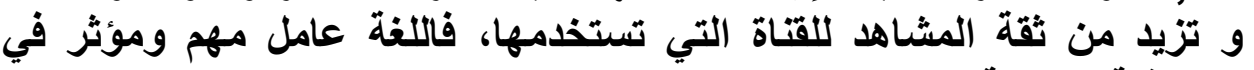
مصداقية الرسالة. وجاء في المرتبة الأخيرة "عدم التهوين أو التهويل في القضايا" كأقل عناصر

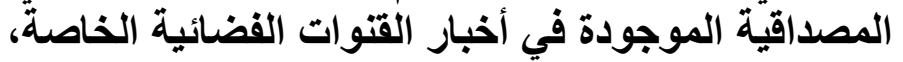

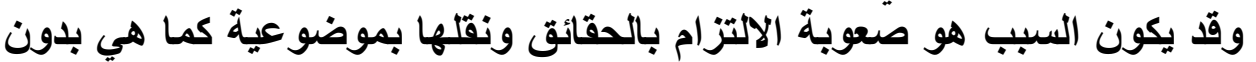

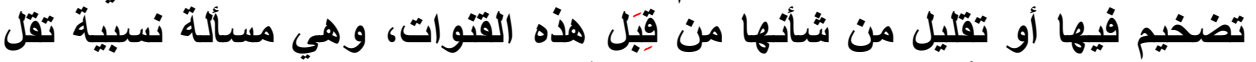

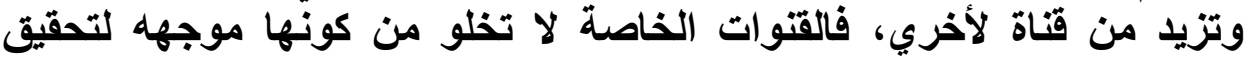

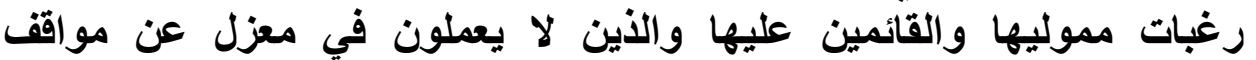

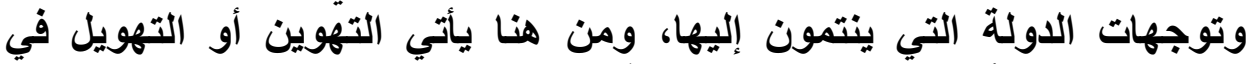
القضايا لتحقيق أغراض وتوجيات التئون معينة. 
وبشكل عام نلاحظ أن أخبار القتوات الفضائية الخاصة قات حظيت الفئ بدرجة

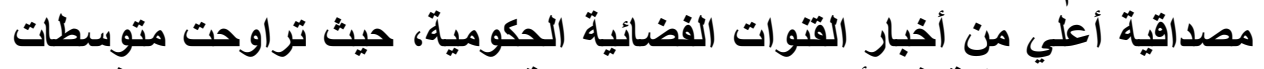

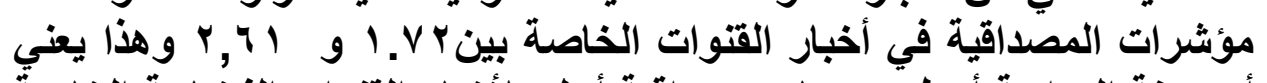

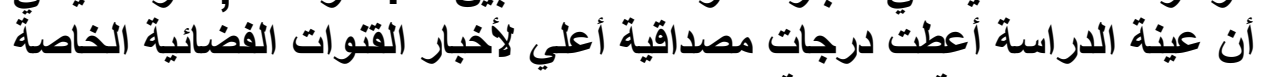
من القتوات الفضائية الحكومية. وتتفق هذه النتيجة مع دراسة نائف مطلق العتيبي حيث توصلت إلي أن الأخبار

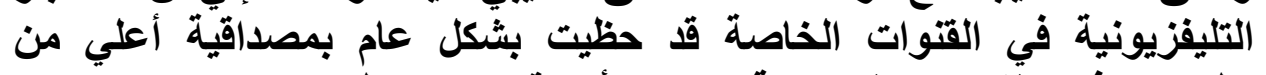

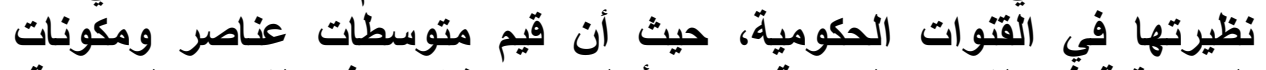

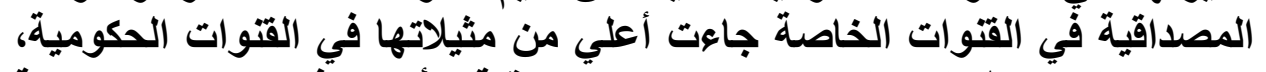

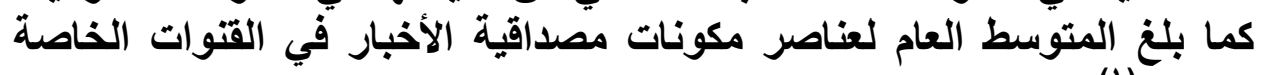
(1)

المقترحات التي يرغب المبحوثون في تقديمها للعمل علي زيادة مصداقية القنوات الفضائية:

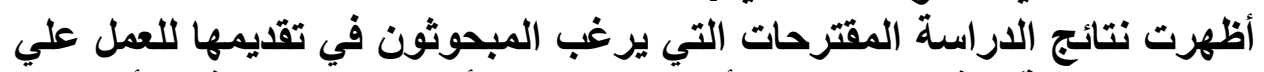

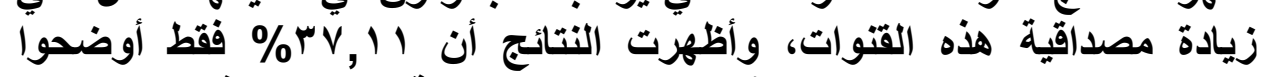
مقترحاتهم للعمل علي تطوير آداء القتوات الفضات الفضائية، ويتضح ذلك من خلال

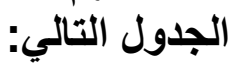

جدول رقم (11) مقترحات أفراد العينة لزيادة مصداقية القتوات

\begin{tabular}{|c|c|c|}
\hline النسبة المئوية & التكرار & الإجابة \\
\hline 9,11 & \&1 & 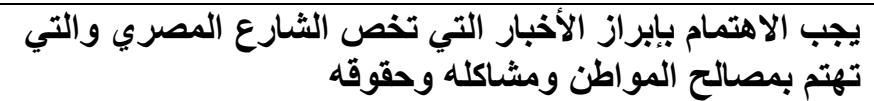 \\
\hline$V, r r$ & $r r$ & مراعاة الصدق في نقل الأخبار \\
\hline$r$ & 9 & الاهتمام بالبرامج واللقاءات الثبابية وفتح باب الحوار لهم \\
\hline$r, 00$ & 17 & يجب عرض الحقائق كاملة \\
\hline$r, r r$ & 10 & الالتزام بمصادر موثُوق بها \\
\hline r, YY & 1. & يجب عرض الرأي والرأي الآخر \\
\hline 0,00 & ro & الالتزام بالمعايير الأخلاقية \\
\hline Y, $\{\leqslant$ & 11 & علدم نشر الثائعات \\
\hline 1,00 & $\mathrm{~V}$ & اختيار إعلاميين معهم مؤهلات أكاديمية ومتخصصين في الإعلام \\
\hline$r v, 11$ & $17 \mathrm{~V}$ & المجموع \\
\hline
\end{tabular}

يتضح من الجدول السابق أن

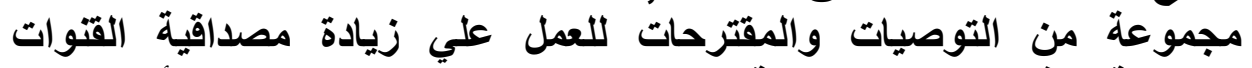

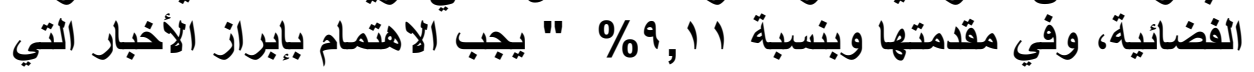

(') (') نائف مطلق فيد العتيبي، مصداقية الأخبار التليفزيونية لاي طلاب وطالبات جامعة الملك r^A 
تخص الثارع المصري والتي تهتم بمصالح المواطن ومشاكلاه وحقوقه " يليه

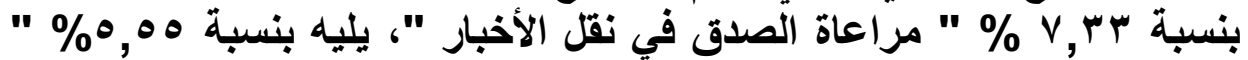

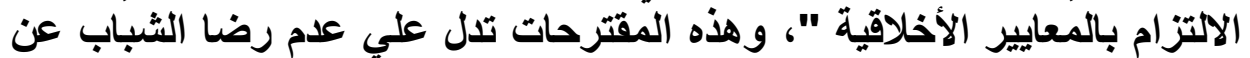

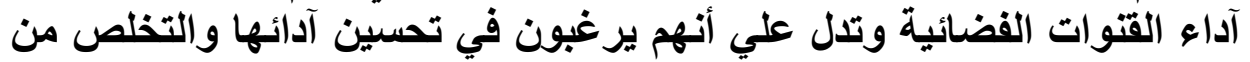

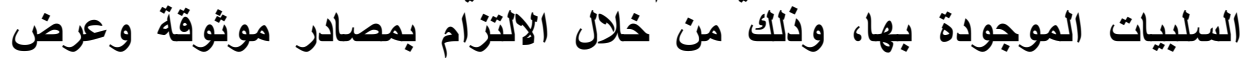

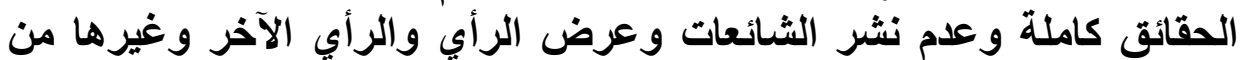
المقترحات المقدمة.

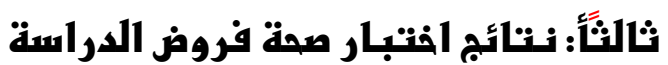

تفترض الاراسة عدة فروض تسعي للتحقق منها، وفيما يلي نتائج اختبار صحة هذه الفروض : الفرض الأول : هنالك فروق ذات الفرو دلالة إحصائية في مؤشرات مصداقية القتوات

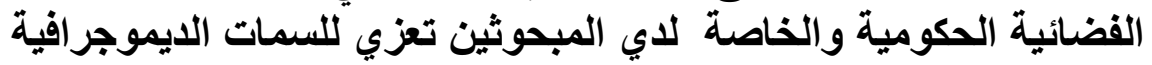

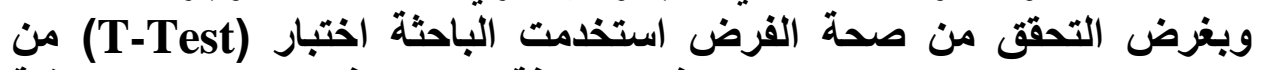
خلال البرنامج الإحصائي SPSS وذلك لمعرفة الفئة الفروق في مؤشرات مصداقية

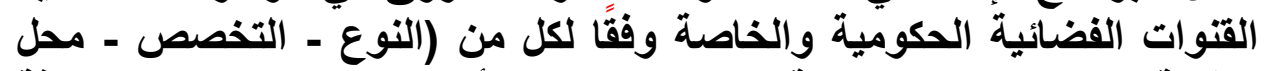
الإقامة)، واستخدمت الباحثة تحليل التباين الأحادي (ANOVA) لمعرفة وفئة

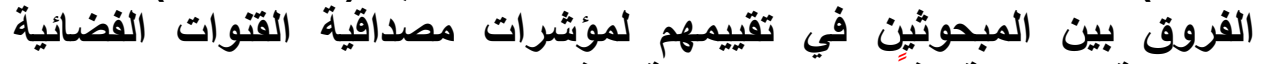

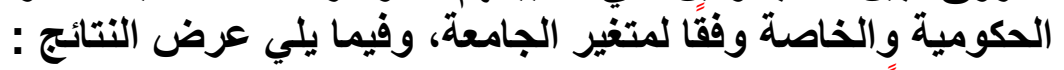

$$
\text { أولاًا : الجامعة واصة }
$$

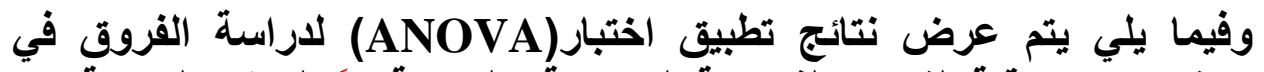

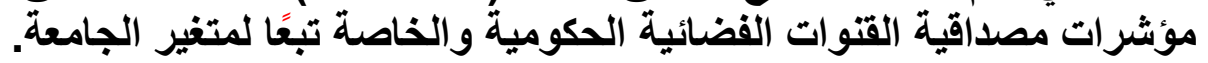

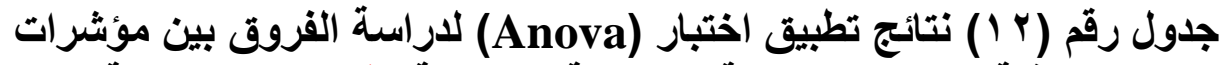

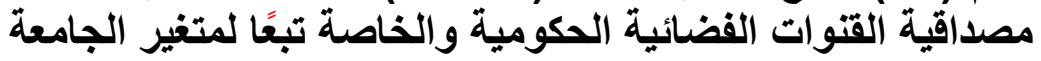

\begin{tabular}{|c|c|c|c|c|c|c|c|}
\hline الإحصائية & $\mathbf{F}$ & المربعات & الدرجية & المجبعوات & التباين & القتاة & اللايموجرافية \\
\hline \multirow{3}{*}{$\because 00$} & \multirow{3}{*}{7.799} & T. $\leqslant O V$ & 1 & r. $\leqslant 0 V$ & المجموعات & \multirow{3}{*}{ حكومية } & \multirow{6}{*}{ الجامعة } \\
\hline & & . & 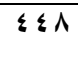 & 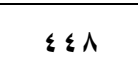 & المجموعات & & \\
\hline & & & $\varepsilon \leqslant 9$ & $\leqslant \leqslant 9$ & الكلي & & \\
\hline \multirow{3}{*}{ 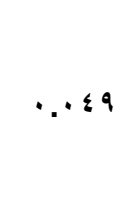 } & \multirow{3}{*}{$r . \wedge 9 \&$} & Y..$\wedge 0$ & 1 & r.0^o & المجموعات & \multirow{3}{*}{ خاصة } & \\
\hline & & $\cdot .74 \varepsilon$ & $\varepsilon \leqslant 1$ & rqv.\&।० & المجموعات & & \\
\hline & & & $\leqslant \leqslant 9$ & $r \ldots .$. & الكلي & & \\
\hline
\end{tabular}

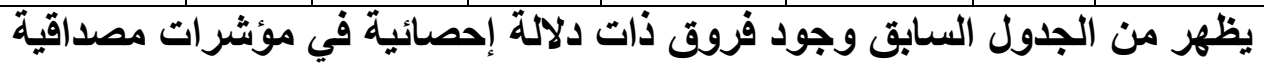

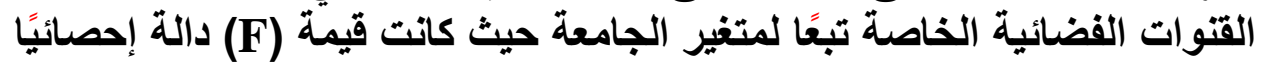




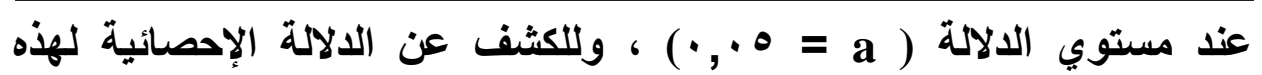

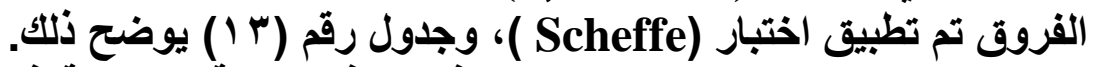

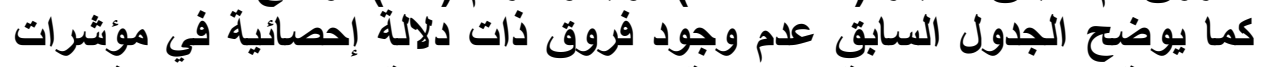

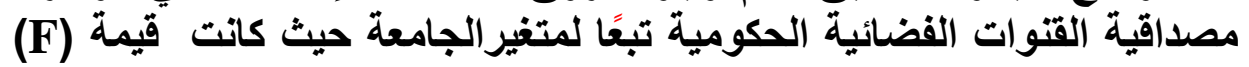

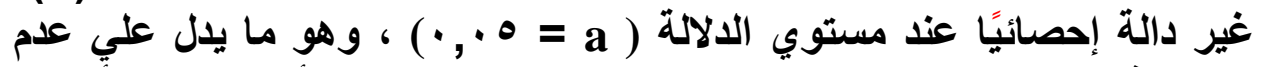

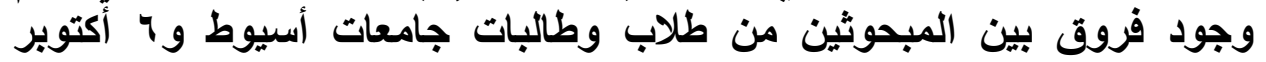

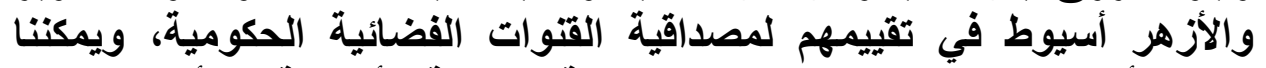

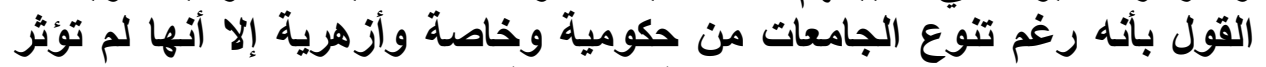
علي تقييم المبحوثين للقنوات الفضئ الفضائية الحكومية.

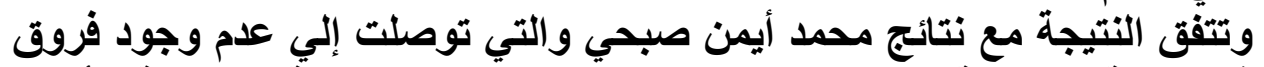

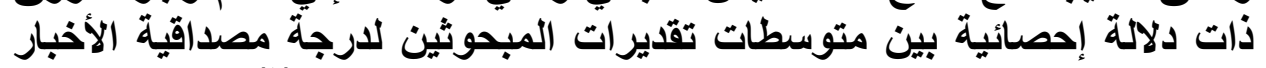

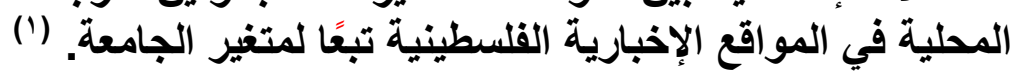

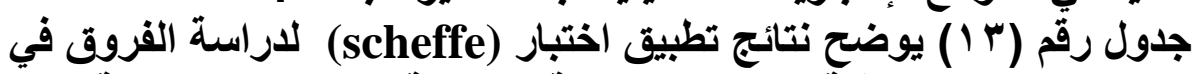

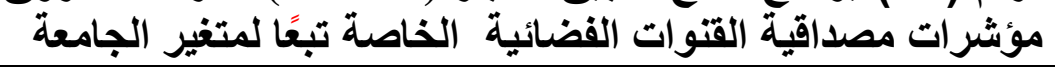

\begin{tabular}{|c|c|c|c|c|}
\hline الأزهرأسيوط & أسيوطة & أكتوبرة 7 & الحستبي & المستوي \\
\hline$\cdot, \cdot \leq q$ & o & - & $r, \leqslant r$ & جامعة 7 أكتوبر \\
\hline$\cdot, \cdots$ & - & & $Y, Y T$ & جامعة أسيوط \\
\hline- & & & $r, 00$ & جامعة الأزهر \\
\hline
\end{tabular}

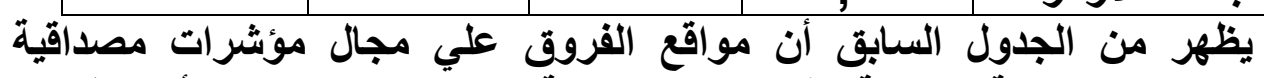

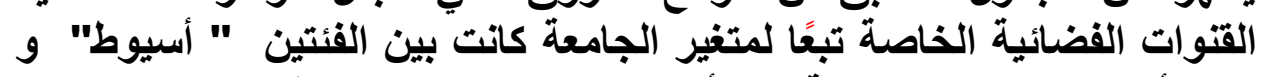

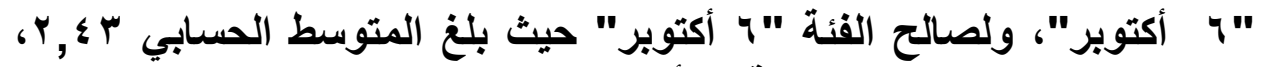

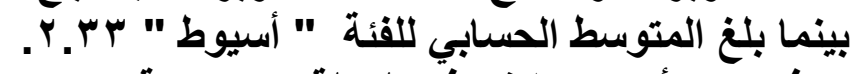

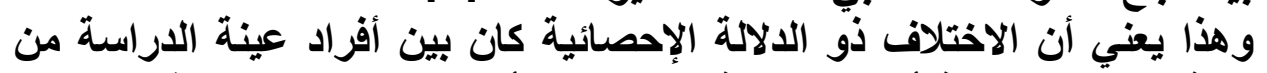

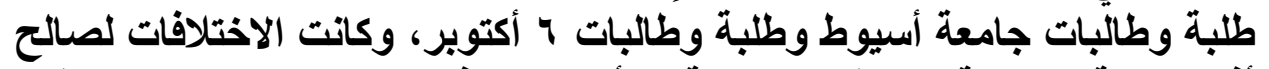

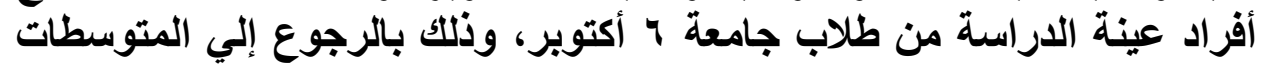

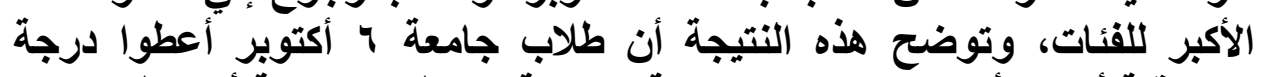
مصداقية أعلي لأخبار القتوات الفضائية الخاصة من طلاب جامعة أسيوط.

$$
\text { ثانيًا: التخصص الاضبار التصا }
$$

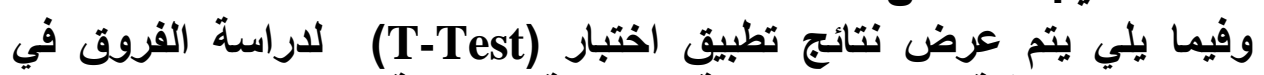

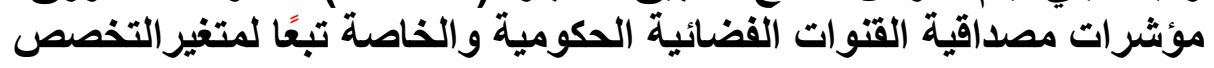

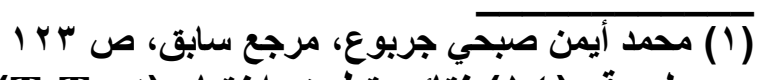

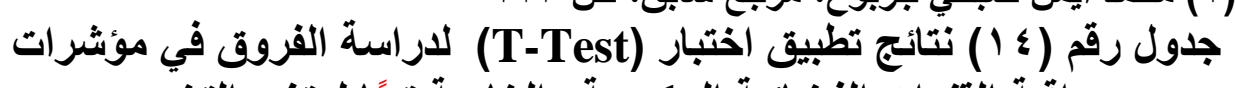

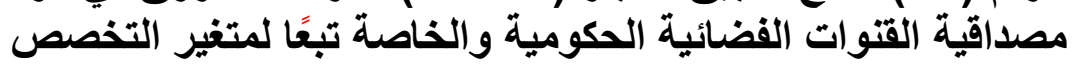


جلة كلية الآداب، جامعة سوهاج، العدد الثالث والخمسون، الجزء الثاني، أكتوبر 9 ا مبم

\begin{tabular}{|c|c|c|c|c|c|c|}
\hline الإحصائية & $\mathbf{T}$ & الالنحرافياري & المتوسط & التخصص & القنوات & الايموجرافيه \\
\hline \multirow{2}{*}{.11} & \multirow{2}{*}{ ב צq.r. } & .001 & 1.91 & نظري & \multirow{2}{*}{ حكومية } & \multirow{4}{*}{ التخصص } \\
\hline & & .000 & $1 . V \wedge$ & عملي & & \\
\hline \multirow{2}{*}{.11.} & \multirow{2}{*}{$1.7 \cdot r=$} &..$\leqslant \leqslant \wedge$ & Y.EV & نظري & \multirow{2}{*}{ خاصة } & \\
\hline & &. .219 & $Y . \& 1$ & عملي & & \\
\hline
\end{tabular}

يظهر من الجدول السابق عدم وجود فروق ذات دلالة إحصائية عند مستوي

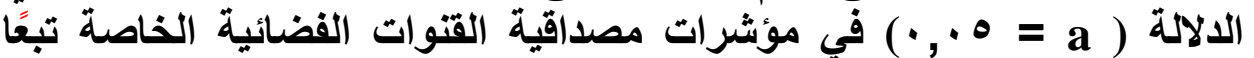
لمتغير التخصص، وهوما يعني أنه لا توجد فروف فئل فئ فين المبحوثين من طلاب

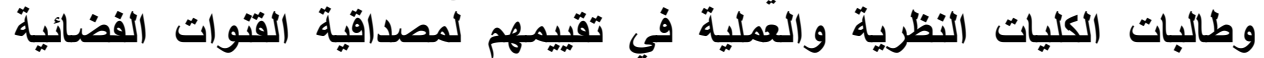

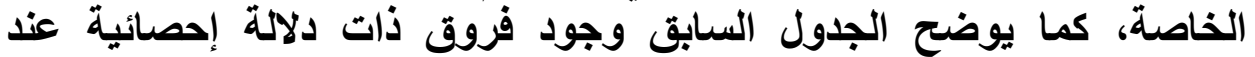

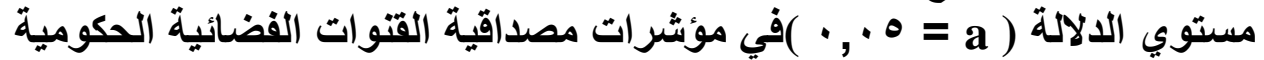
تبعًا لمتغير التخصص وكاتت الفروق لصالح المبحوثين من الكليات النظرية،

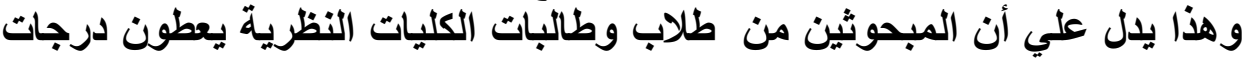

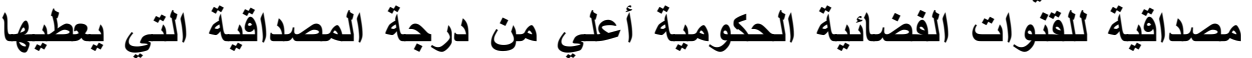

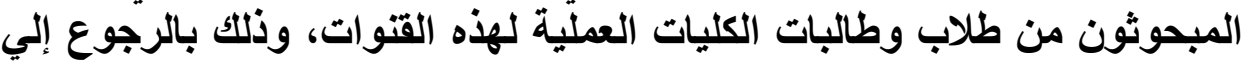
المتوسطات الأكبر للفئات. وقد يرجع ذللك إلي أن طلاب وطالبات الكليات العملية يميلون إلي تحليل

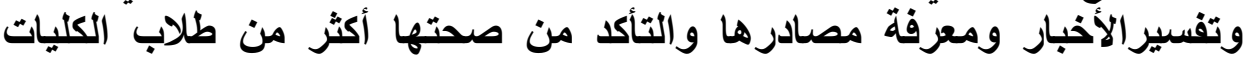

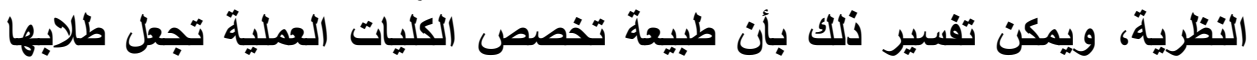
يميلون للتعق وتفسير الظواهر والمواقف والأحداث التي يمرون بها، ولذان

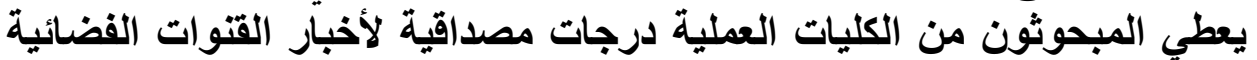
أقل من المبحوثين من الكليات النظرية.

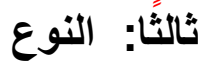

وفيما يلي يتم عرض نتائج تطبيق اختبار (T-Test) لاراسة الفئة الفروق في

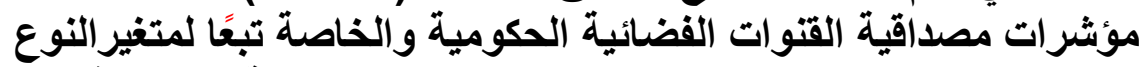

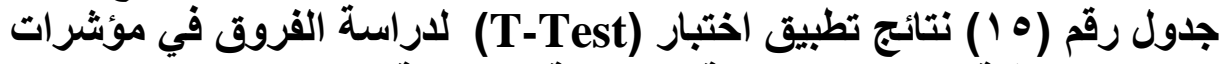

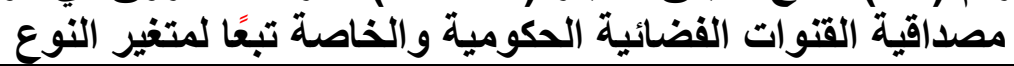

\begin{tabular}{|c|c|c|c|c|c|c|}
\hline الإحصائية & $\mathbf{T}$ & المعياري & الحستبي & التخصص & القتوات & الايموجرافية \\
\hline \multirow{2}{*}{$\cdot r \leq 4$} & \multirow{2}{*}{$\because 9 \leq \leq$} & $\because 0 \vee 9$ & $1 . \wedge Y$ & ذكر & \multirow{2}{*}{ حكومية } & \multirow{4}{*}{ النوع } \\
\hline & & $\because .0 Y 0$ & $1 . \wedge \mathrm{V}$ & أنثي & & \\
\hline \multirow{2}{*}{..$I V Y$} & \multirow{2}{*}{$1 . r 7 V=$} & 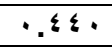 & Y. $\leqslant V$ & ذكر & \multirow{2}{*}{ خاصة } & \\
\hline & & $\cdot \varepsilon r q$ & Y.\&1 & أنثي & & \\
\hline
\end{tabular}


يظهر من الجدول السابق عدم وجود فروق ذات دلالة إحصائية عند مستوي

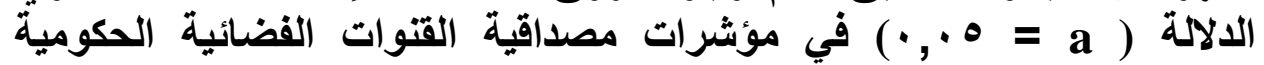

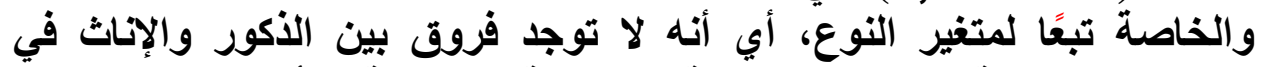

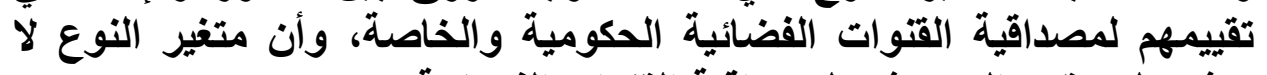

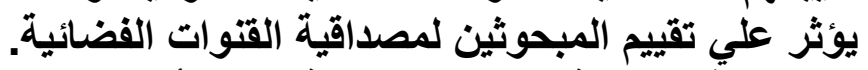

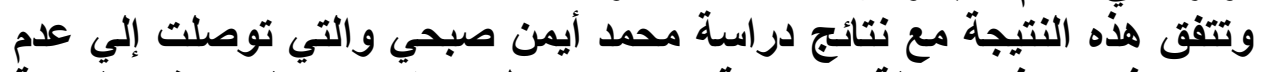

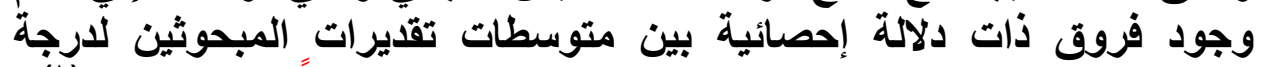

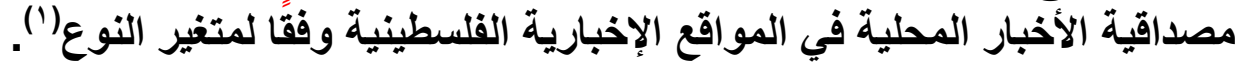

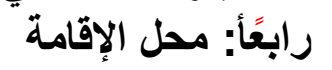

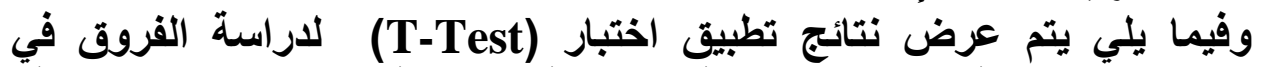

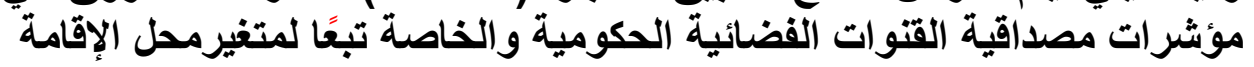

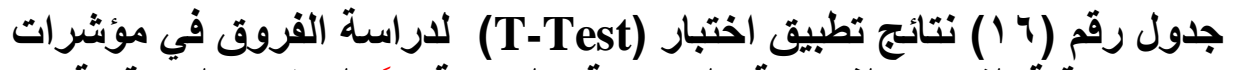

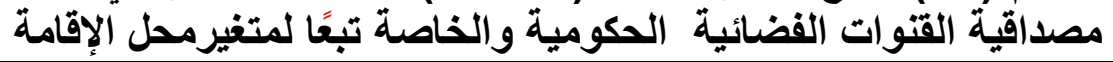

\begin{tabular}{|c|c|c|c|c|c|c|}
\hline الإحصائية & $\mathbf{T}$ & الالحعياري & المتوسط & التخصص & القتوات & الايموجرافية \\
\hline \multirow{2}{*}{.$r \wedge}$. & \multirow{2}{*}{$1 . \cdot \Lambda r$} & .000 & $1 . \wedge r$ & ريف & حكه مية & \multirow{4}{*}{ محل الإقامة } \\
\hline & & .001 & 1.19 & حضر & حخوميي & \\
\hline \multirow{2}{*}{. YY } & \multirow{2}{*}{$1 . r i v$} &..$\leqslant 0$. & $r . \leqslant Y$ & ريف & \multirow{2}{*}{ خاصة } & \\
\hline & & 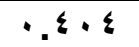 & $Y . \leqslant V$ & حضر & & \\
\hline
\end{tabular}

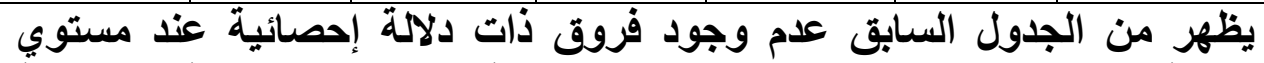

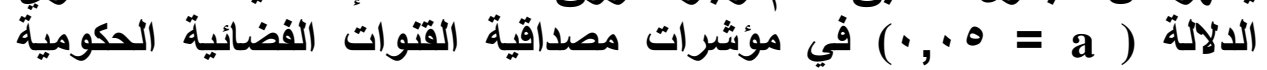

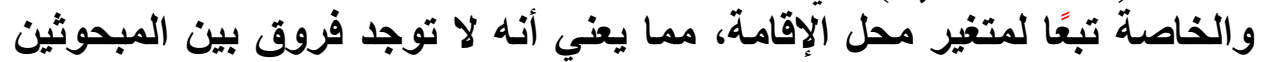

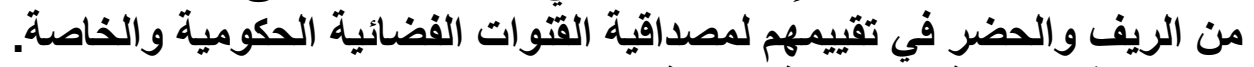

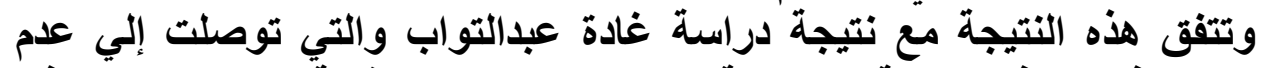

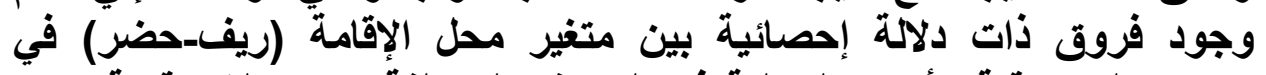

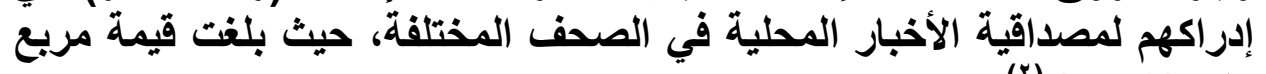
كاي (i)

الفرض الثاني: توجد علاقة ارتباطية طردية بين معدل تعرض الثباب الجامعي

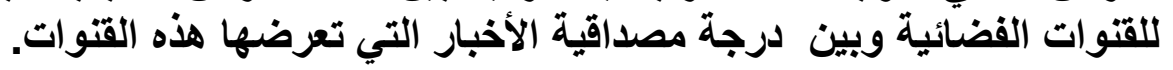

محمد أيمن صبحي جربوع، مصداقية الأخبار المحلية في المو اقع الإخباريـة الفلسطينية

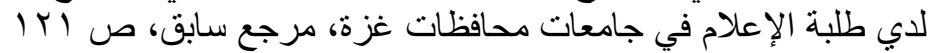

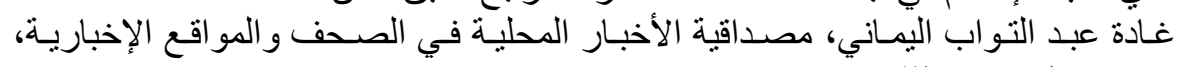


مجلة كلية الآداب، جامعة سوهاج، العدد الثالث والخمسون، الجزء الثاني، أكتوبر 19 • ب م

جدول رقم (IV) مصفوفة معاملات ارتباط بيرسون بين معدل تعرض الشباب

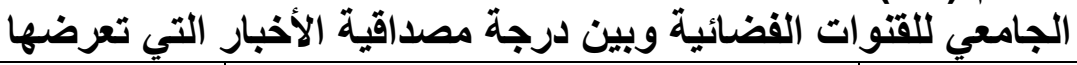

\begin{tabular}{|c|c|c|c|}
\hline \multirow{2}{*}{ القتوات مصداقية } & \multicolumn{2}{|c|}{ معدل تعرض الشباب الجامعي للقتوات } & \multirow[t]{2}{*}{ الأبعاد } \\
\hline & خاصة & حكومية & \\
\hline. $.7 \varepsilon$ & $* * . .1 \leq \ldots$ & - & حكومية \\
\hline$* * . .1 \leq V$ & - & & خاصة \\
\hline & & & مصداقية القنوات \\
\hline
\end{tabular}

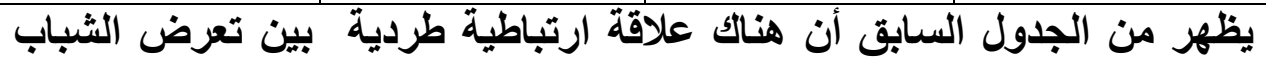

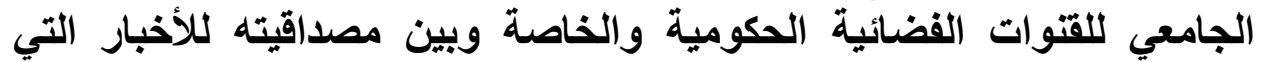

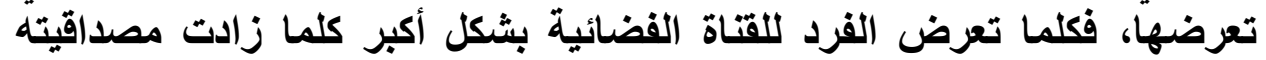

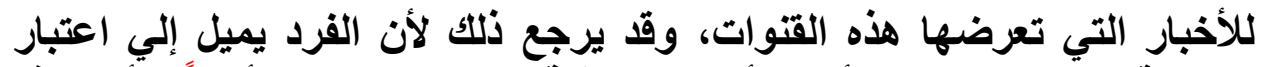

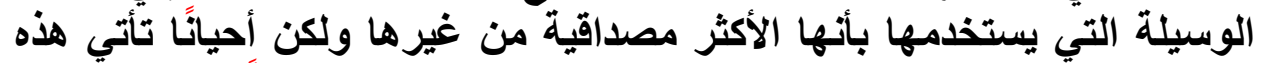

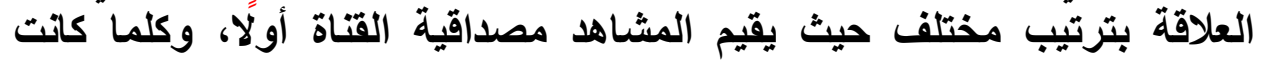

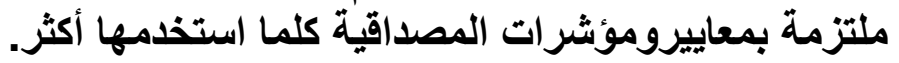

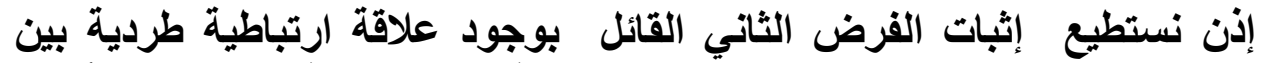

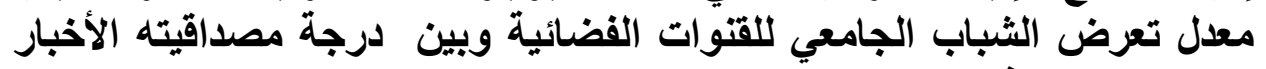

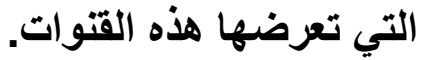

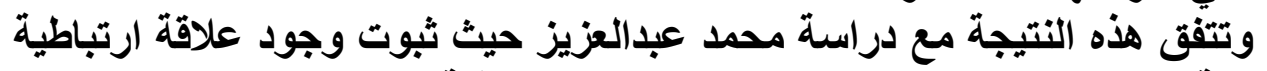

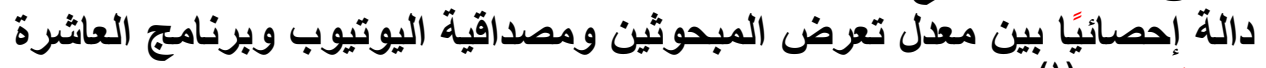

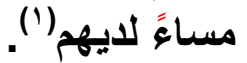
الفرض الثالث: القتوات الفضائية المصرية الخاصة أكثر مصداقية من القتوات

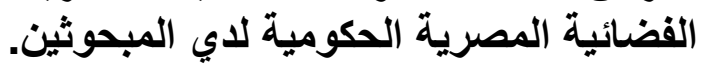

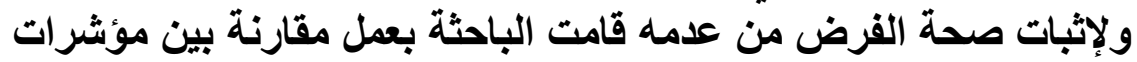

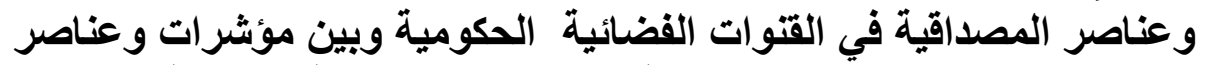

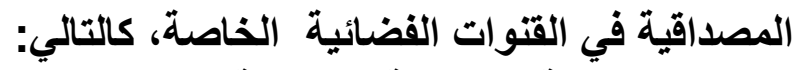

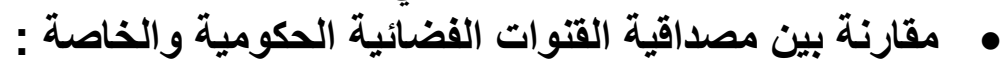
ولتسهيل عملية المقارنة بين المصداقية في القتوات الفية الفضائية الفية الحكومية

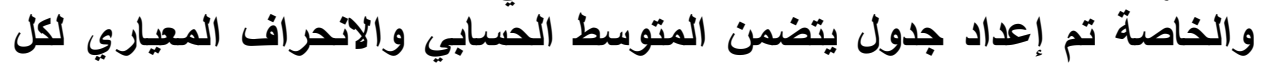

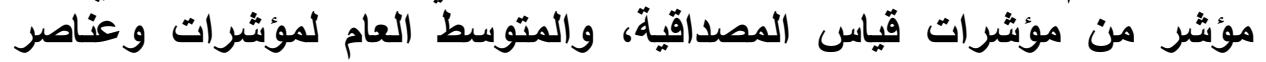
مصداقية القتوات الفضائية الحكومية والقنوات الفضائية الخئة الخاصة، كالتالي : 
اتجاهات الثباب الجامعي نحو مؤشرات مصداقية الأخبار بالقنوات الفضائية: دراسة ميدانية

جدول رقم (1) مقارنة بين مدي مصداقية القتوات الحكومية ومصداقية القتوات الخاصة

\begin{tabular}{|c|c|c|c|c|c|c|}
\hline \multicolumn{3}{|c|}{ الخاصة } & \multicolumn{3}{|c|}{ الحكومية } & \multirow{2}{*}{ مؤشرات المصداقية } \\
\hline الترتيب & الانحراف & المتوسطي المسي & الترتيب & الانحراف & المتوسطي & \\
\hline 0 & $\cdot, 017$ & Y.Or & $r$ & $\cdot, \wedge \leq 7$ & Y.11 & الأحورية والحالية في تغطية \\
\hline 1. & $\cdot, \curlyvee \wedge \wedge$ & r.o. & 9 & $\because \wedge 00$ & $1 . \Lambda$ & الدقة في نقل الأحداث \\
\hline $1 \varepsilon$ & $\cdot, \wedge \leq q$ & Y. YV & ir & $\because \wedge \bullet r$ & $1 . V \cdot$ & فصل الرأي عن المعلومات \\
\hline Ir & $\cdot, \vee \vee \diamond$ & $Y . \varepsilon Y$ & 7 & $\cdot$, AYr & 1.10 & تقديم أدلة وبراهين \\
\hline$r$ & $\cdot, 7 \vee \wedge$ & Y.OV & $r$ & $\bullet, \wedge 9$. & $r, \cdots$ & وبسيطة الأحداث بلغة سهلة \\
\hline 11 & $\cdot, \mathrm{V} \bullet \wedge$ & $Y . \Sigma V$ & 1. & $\cdot, \wedge \bullet \leq$ & $1 . V \varepsilon$ & توثادرها المطلومات ونسبها إلي \\
\hline 7 & $\cdot, V \leq \varepsilon$ & $Y .01$ & $\varepsilon$ & $\cdot, \wedge \leq 1$ & 1.90 & الوضوح في اللغة والأفكار \\
\hline 10 & $\cdot$, גד & $1 . V Y$ & 1 & $\cdot, \wedge$ • & r.Mr & القضايا التهوين أوالتهويل في \\
\hline$\varepsilon$ & $\cdot, \vee 19$ & $r . \Delta r$ & Ir & $\cdot, \wedge \leq 0$ & 1.81 & عرض الحدث بمختلف جوانبه \\
\hline$r$ & $\cdot, 794$ & $Y .0 \Lambda$ & 10 & $\cdot, \wedge r r$ & $1.7 \mathrm{~V}$ & الجمهور \\
\hline V & $\cdot, V \leq \leq$ & $Y .01$ & 11 & $\cdot, \wedge \leq \neg$ & $1 . V Y$ & الجمبهور عن هموم واحتياجات \\
\hline 9 & $\cdot, V \otimes r$ & Y.O. & 0 & $\cdot, \wedge>0$ & $1 . \wedge V$ & الالتزام بالمعاييز الأخلاقية \\
\hline 14 & $\cdot, \mathrm{V} \bullet \wedge$ & $r . \mu \Lambda$ & $1 \varepsilon$ & $\cdot, \wedge 11$ & 1.71 & 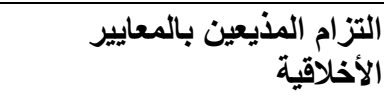 \\
\hline 1 &. .779 & 9.71 & V & $\cdot, \wedge \cdot \wedge$ & 1.19 & فيها اعتماد علي مصادر موثوق \\
\hline$\Lambda$ & $\cdot, V Y r$ & r. 01 & $\wedge$ & $\cdot, \wedge M_{1}$ & 1.11 & الاعتمصاد علي مصادر \\
\hline \multicolumn{3}{|c|}{$Y . \varepsilon \varepsilon$} & \multicolumn{3}{|c|}{1.10} & المتوسط العام \\
\hline \multicolumn{3}{|c|}{$. . \leqslant \Psi \leqslant$} & \multicolumn{3}{|c|}{.007} & الاتحراف المعياري \\
\hline
\end{tabular}

يتضح من الجدول السابق أن مصداقية الأخبار في القنوات الفضائية الخاصة أعلي من مصداقية الأخبار في القتوات الفضائية الحكومية حيث إن متوسطات 


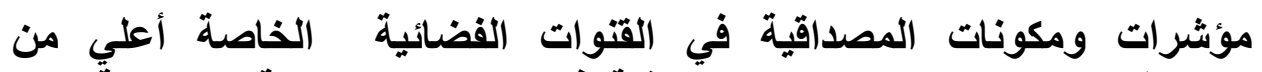

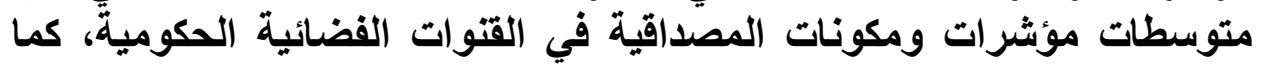

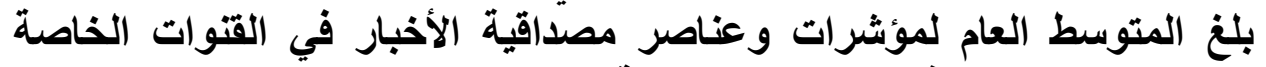

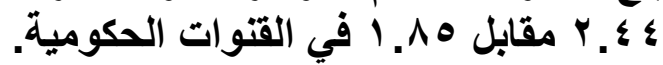

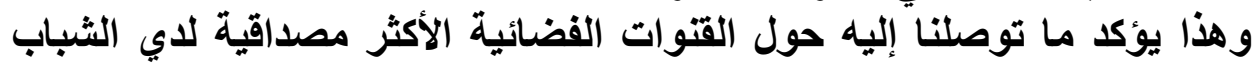

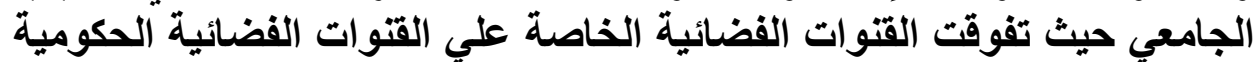

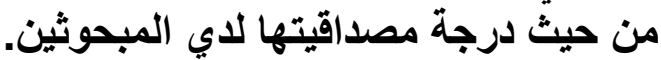

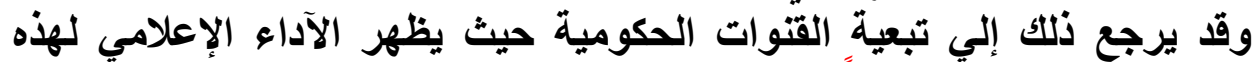

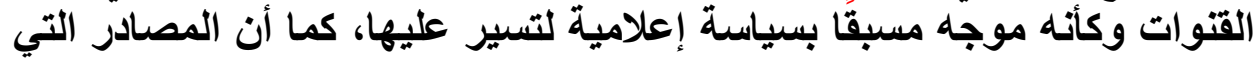

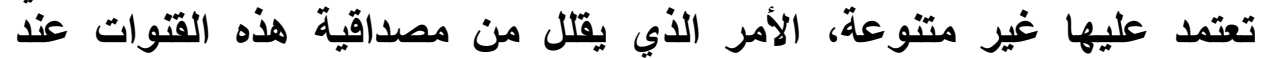

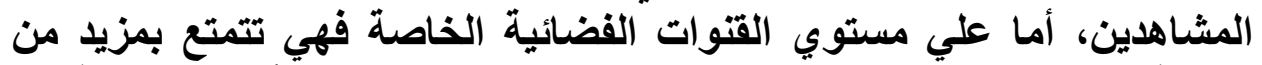

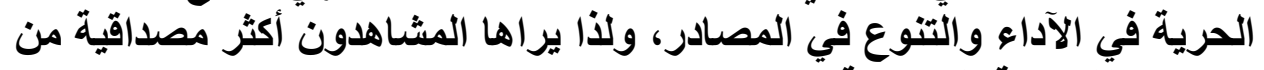

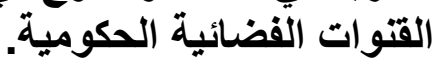
إذن نستطيع إثبات الفرض السابع القائل بأن القنوات الفئة الفضائية الفية المصرية الخاصة

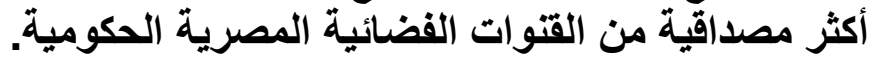

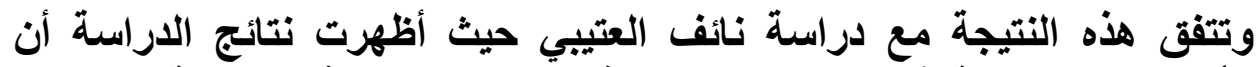

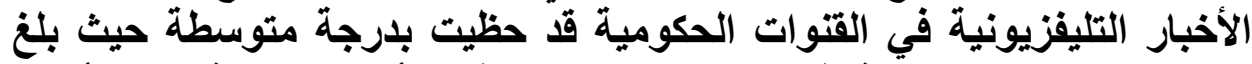

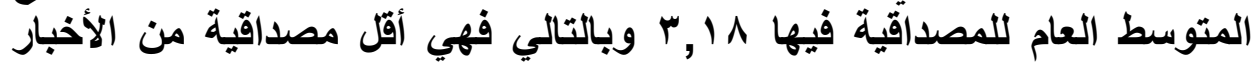

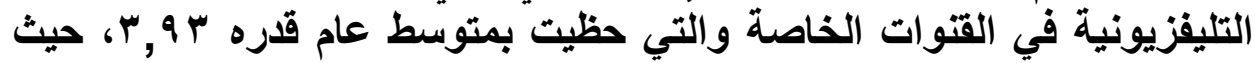

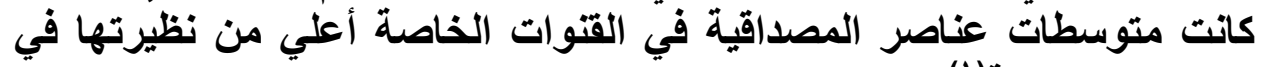

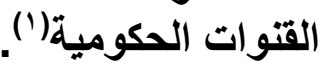

توصبات الدراستة :

في ضوء النتائج السابقة لهذه الدراسة، توصلت الباحثة إلي مجموعة من التوصيات، وهي كالتالي :

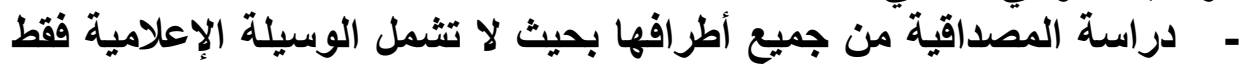

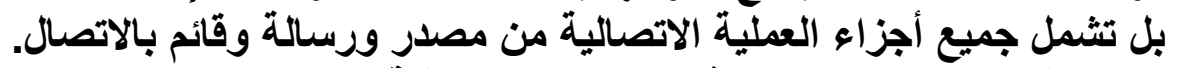

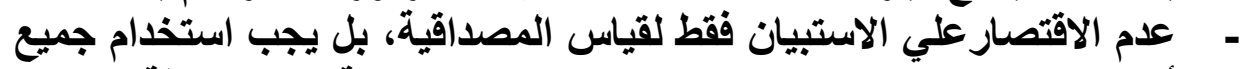

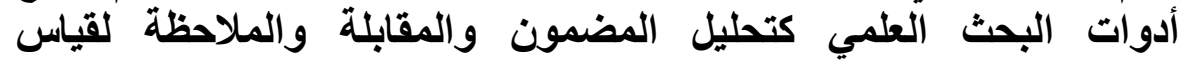

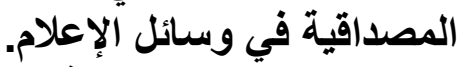

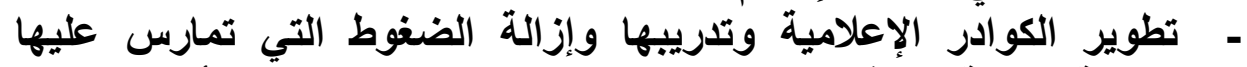
وإتاحة الحرية لهم فيما لا يتعارض مع قيم الإية والمجتمع المصري وأخلاقياته. 


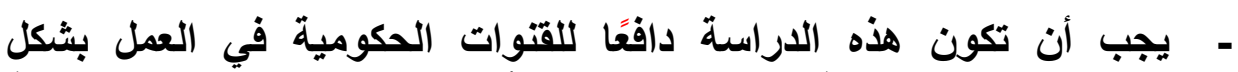

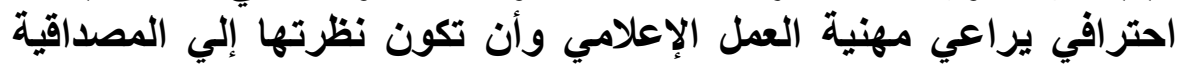
أكثر إيجابية فيمًا يحقق رغبات المتابعين لها.

\section{قائمة المراجهر}

\section{أولًا : المراجه العربية}

أَ-11

- عاطف عدلي العبد، الإعلام والمجتمع : الأسس النظرية والنماذج التطبيقية،

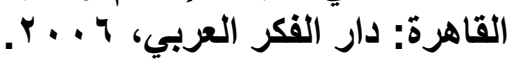

- عزيزة عبده، الإعلام السياسي والهرب، الرأي العام في دراسة ترتيب الأولويات، دار

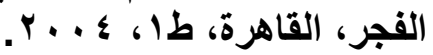

- محمود السيد أبو النيل، علم النفس الاجتماعي : عربيًا وعالميًا، مكتبة الأنجلو

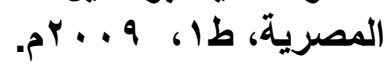

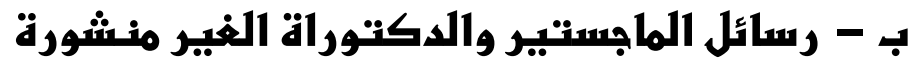

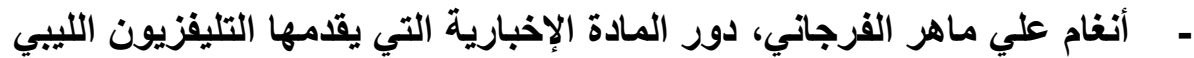

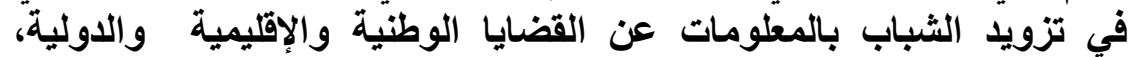
رسالة ماجستير، جامعة القاهرة، كلية الإعلام، قسم الإذاعة والإلئة والتليفزيون،

- جيلان محمود عبد الرازق شرف، دور التليفزيون في نشر الثقافة العلمية

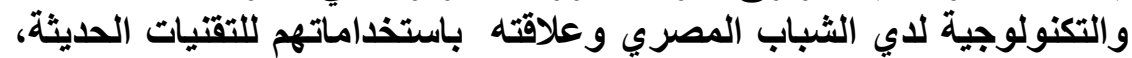

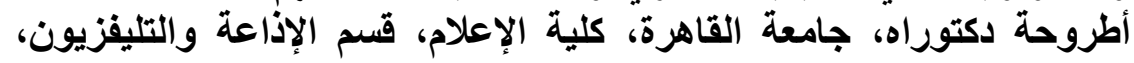

. r...

- رحاب عبدالناصر عوض محمد، مصداقية القتوات التليفزيونية الحكومية والخاصة لاي الجمهور المصري، رسالة ماجستير، جامعة أسيوط، كلية

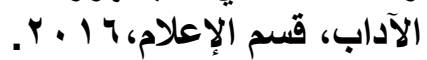

- شيرين محمد كدواني، مصداقية الإنترنت وعلاقتها باستخدام الجمهور

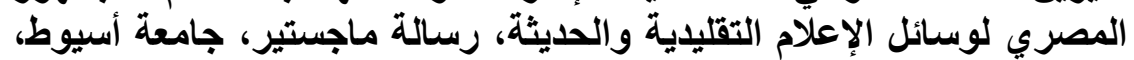

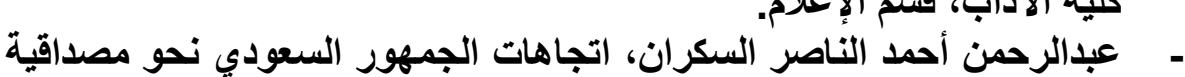

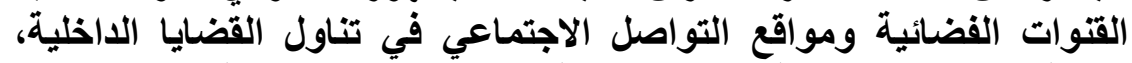

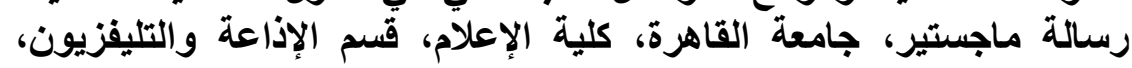
- فاطمة محمد صالح، العوامل المؤثرة علي مصداقية المادة الإخبارية

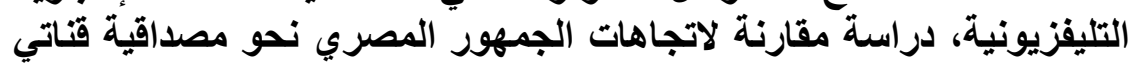


النيل للأخبار والجزيرة الإخبارية، رسالة ماجستير، جامعة القاهرة، كلية

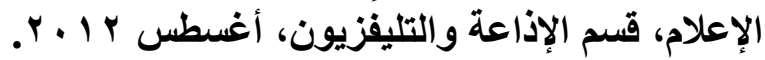

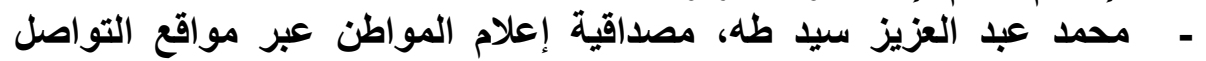

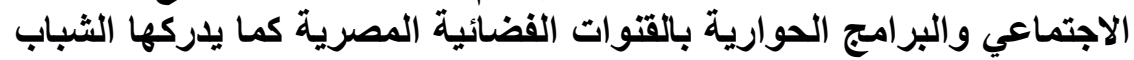

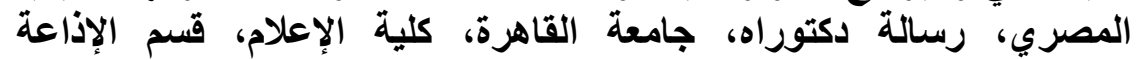

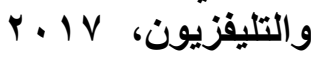
- هبة حسين عبد الوهاب، مستويات مصداقية القنوات الإخبارية العربية

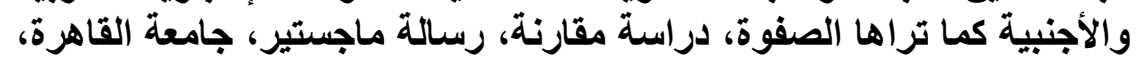

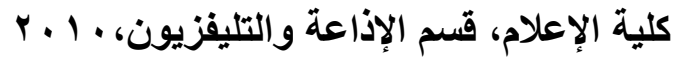

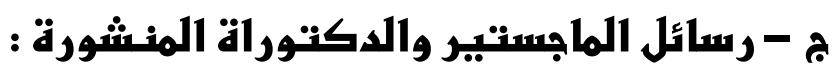

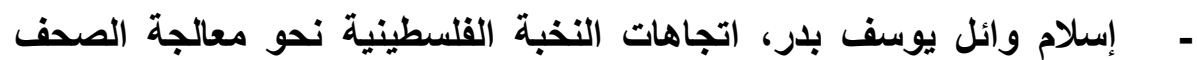

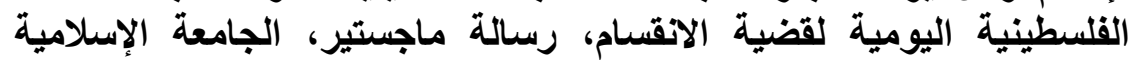

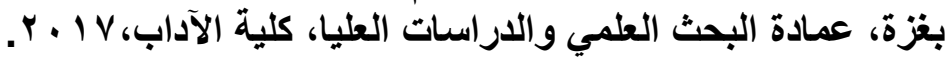

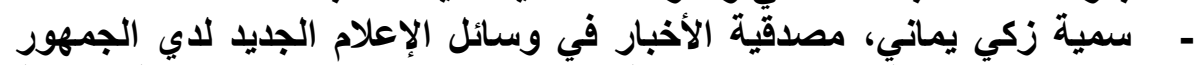

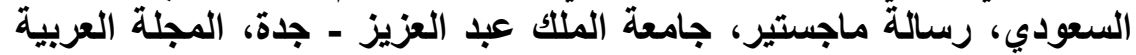

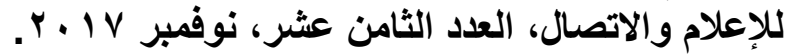

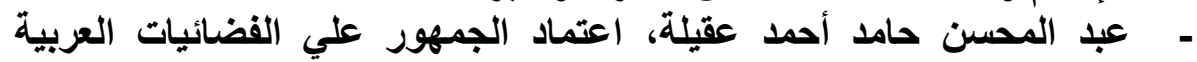

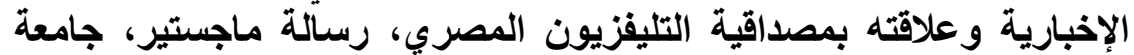

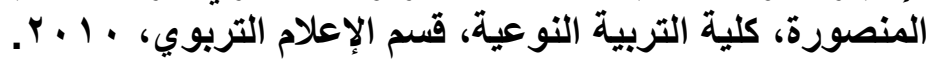

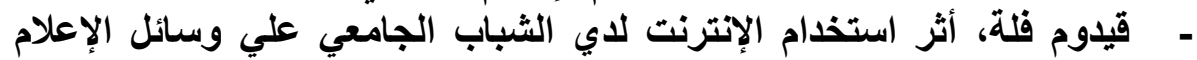

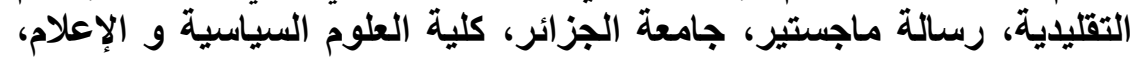

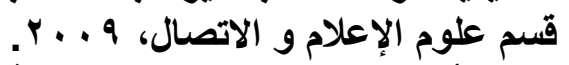

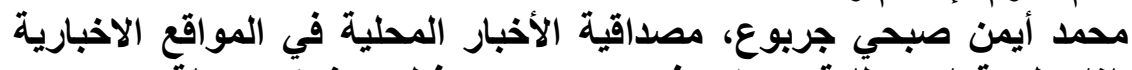

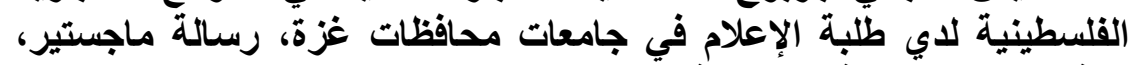

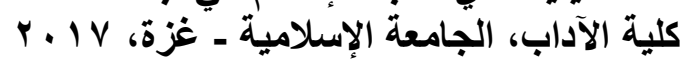

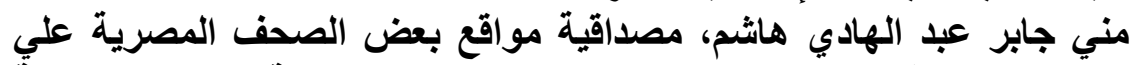

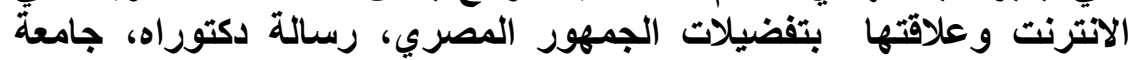

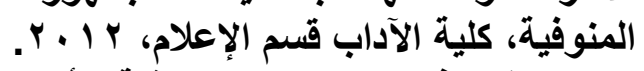

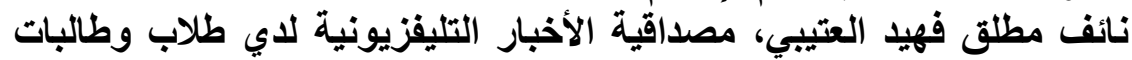

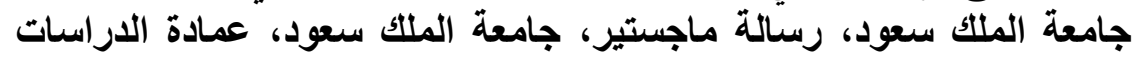

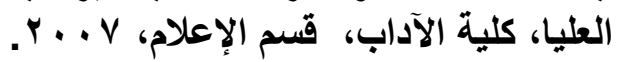

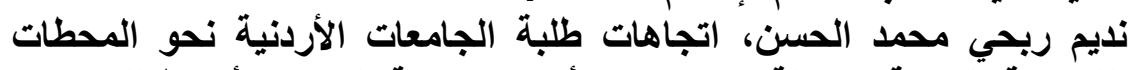

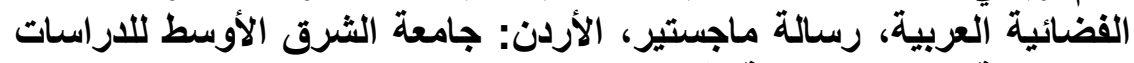

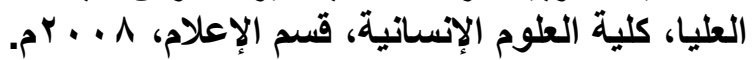

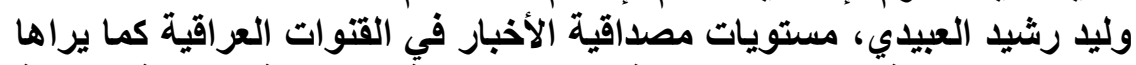

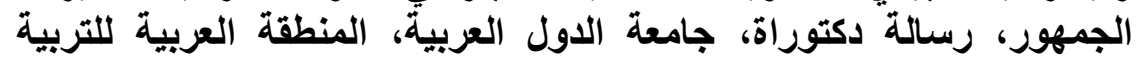


والثقافة والعلوم،معهد البحوث والدراسات العربية، قسم البحوث والدراسات

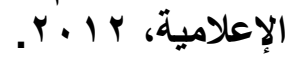

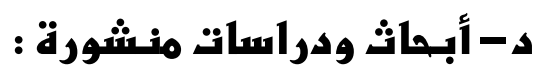

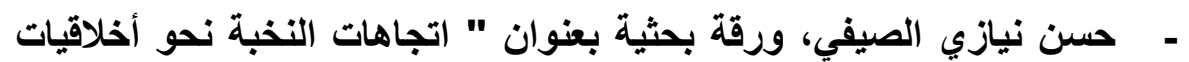

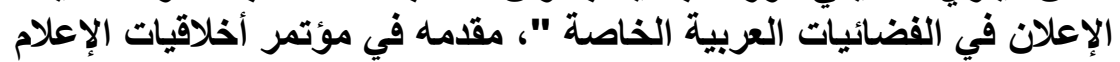

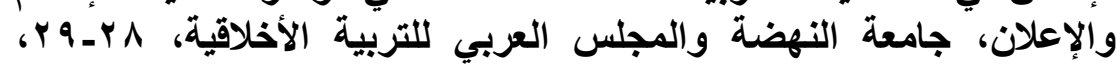

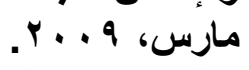

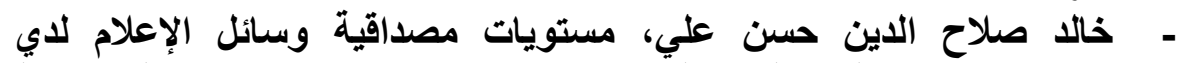

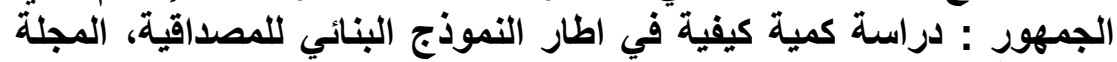

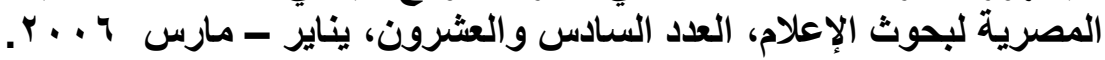

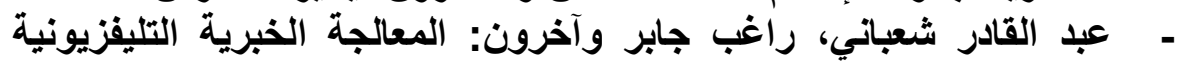

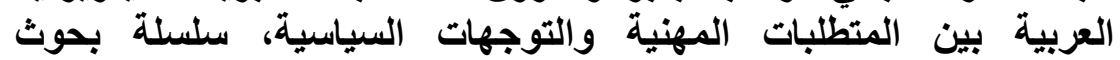

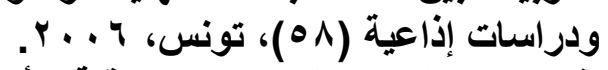

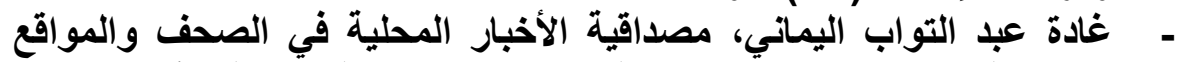

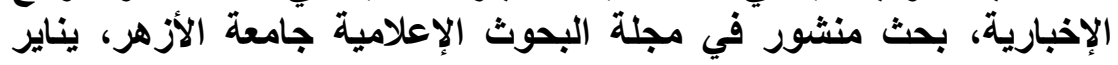

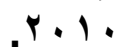
- وائل إسماعيل حسن عبدالباري، مصداقية المواقع الإخبارية علي الإنترنت

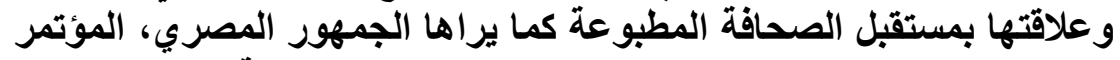

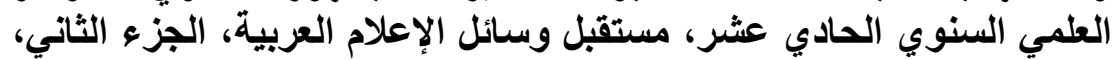

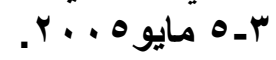

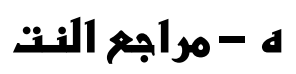

- عربي المصري، هل انُتُقت مصداقية وسائل الإعلام لأن أعدادها زادت ؟ علي موقع الجمعية السورية للعلاقات العامة

Available a:http://www.sprasy.com/website/?more=3688\&category_id=124

نانـبًا : المراجم الأجمنبـبة:

- Daekyung kim, Thomas J. Johnson, A shift in Media Credibility: Comparing Internet and Traditional News Sources in South Korea, International Communication Gazette, Volume71 Issue4, June2009

Available at : http://journals.sagepub.com/home/gaz

- Thomas B Christie, Andrew M Clark, Believe it or not: Understanding the credibility and effectiveness of Radio Sawa in the UAE , International Communication Gazette, vol.73, no. 4,2011

Available at :http://journals.sagepub.com/home/gaz 